Energy Systems Environmental Restoration Program

ORNL Environmental Restoration Program

\title{
Sampling and Analysis Plan for the Site Characterization of the Waste Area Grouping 1 Groundwater Operable Unit at Oak Ridge National Laboratory
}

Date Issued-November 1994

Prepared by

CDM Federal Programs Corporation

under General Order 13B-99052C

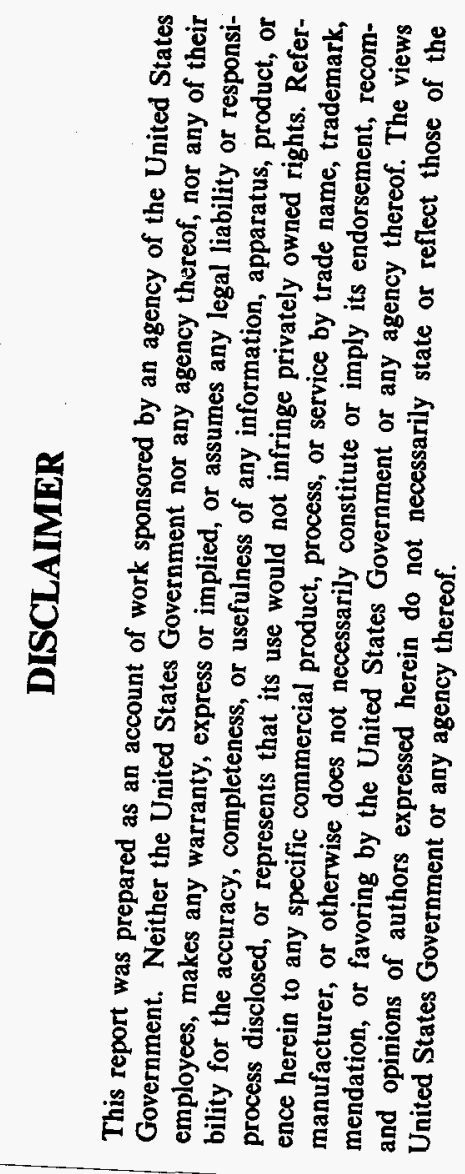

Office of Environmental Restoration and Waste Managem

Prepared for

U.S. Department of Energy under budget and reporting code EW 20

Environmental Restoration and Waste Management Programs

Oak Ridge National Laboratory

Oak Ridge, Tennessee 37831-6285

managed by

MARTIN MARIETTA ENERGY SYSTEMS, INC.

for the

U.S. DEPARTMENT OF ENERGY

under contract DE-AC05-84OR21400 


\section{DISCLAIMER}

Portions of this document may be illegible in electronic image products. Images are produced from the best available original document. 
Sampling and Analysis Plan

for the Groundwater Operable Unit,

Waste Area Grouping 1,

Site Characterization at

Oak Ridge National Laboratory,

Oak Ridge, Tennessee

Approvals

R. R. Lee

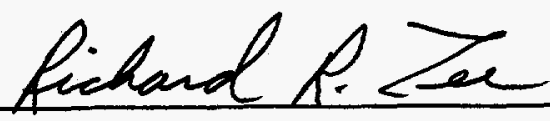

WAG 1 Project Manager

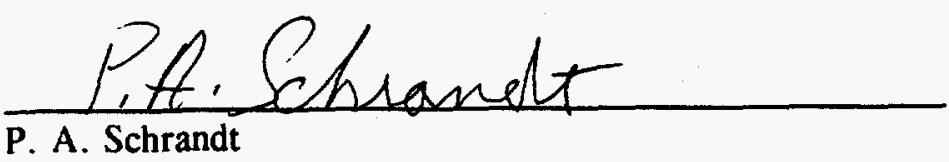

Environmental Restoration Quality Assurance Specialist
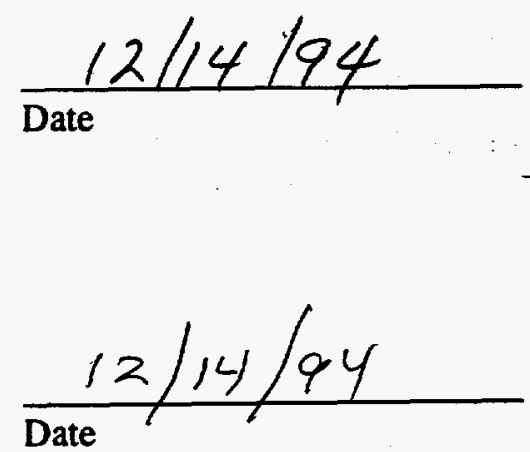


\section{CONTENTS}

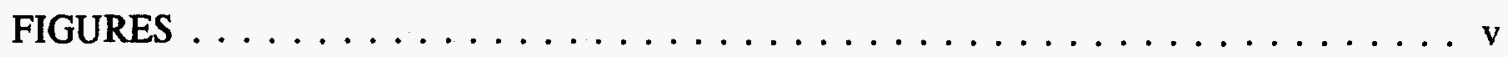

TABLES $\ldots \ldots \ldots \ldots \ldots \ldots \ldots \ldots \ldots \ldots \ldots \ldots \ldots \ldots \ldots \ldots \ldots$

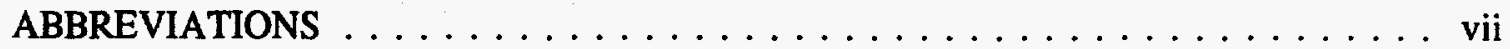

EXECUTTVE SUMMARY $\ldots \ldots \ldots \ldots \ldots \ldots \ldots \ldots \ldots \ldots \ldots$

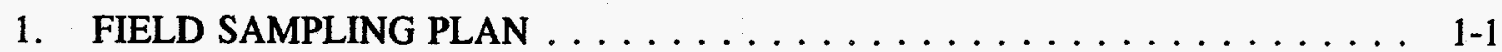

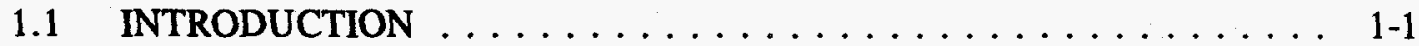

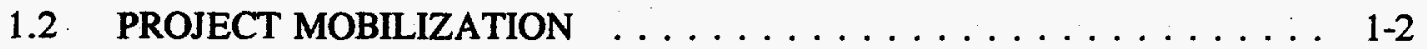

1.2.1 Readiness Review . . . . . . . . . . . . . . . . 1-2

1.2.2 Field Planning Meeting . . . . . . . . . . . . . . . . 1-3

1.2 .3 Use of the Field Operations Facility . . . . . . . . . . . . . . 1-3

1.3 DESCRIPTION AND HISTORY OF COREHOLE 8

GROUNDWATER CONTAMINANT PLUME . . . . . . . . . . . 1-3

1.4 COREHOLE 8 GROUNDWATER PLUME CHARACTERIZATION $\ldots .$.

1.4.1 Data Quality Objectives

for CH-8 Plume Characterization $\ldots \ldots \ldots \ldots \ldots \ldots \ldots$

1.4.2 Geoprobe Installation . . . . . . . . . . . . . . 1-5

1.4 .3 Geoprobe Water Sampling . . . . . . . . . . . . . 1-5

1.5 GROUNDWATER LEVEL MONITORING OBJECTIVES $\ldots \ldots \ldots \ldots$. . . .

1.5.1 Monitoring Locations and Frequencies . . . . . . . . . . . . 1-6

1.5.2 Manual Water Level Measurements . . . . . . . . . . . . . . . . . 1-8

1.6 GROUNDWATER QUALITY SAMPLING AND ANALYSIS

OBJECTIVES . . . . . . . . . . . . . . . . . . . . . . . . . 1-9

1.6.1 Data Quality Objectives for Groundwater Sampling . . . . . . . 1-9

1.6.2 Sampling Locations, Frequencies, and Analytes . . . . . . . . 1-11

1.6.3 Groundwater Level Measurements . . . . . . . . . . . . . . . . . 1-12

1.6.4 Monitoring Well Purging . . . . . . . . . . . . 1-17

1.6 .5 Groundwater Sampling . . . . . . . . . . . . . . 1-18

2. DATA MANAGEMENT FOR FIELD ACTIVITIES . . . . . . . . . . 2-1

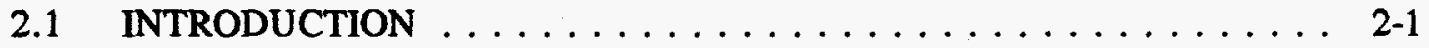

2.2 FIELD DOCUMENTATION $\ldots \ldots \ldots \ldots \ldots \ldots \ldots \ldots \ldots \ldots$

2.3 PROCEDURES FOR COLLECTING GROUNDWATER
LEVEL DATA $\ldots \ldots \ldots \ldots \ldots \ldots \ldots \ldots \ldots \ldots \ldots \ldots \ldots \ldots \ldots \ldots \ldots \ldots \ldots$

2.4 PROCEDURES FOR COLLECTING GROUNDWATER

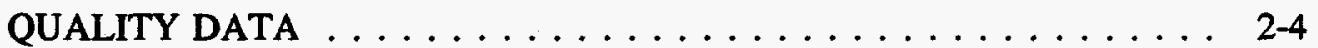

2.5 COMPLETING SAMPLE COLLECTION FORMS $\ldots \ldots \ldots \ldots \ldots \ldots$.

2.6 SAMPLE IDENTIFICATION AND LABELING $\ldots \ldots \ldots \ldots \ldots \ldots \ldots$

2.7 CHAIN OF CUSTODY . . . . . . . . . . . . . . $2-5$

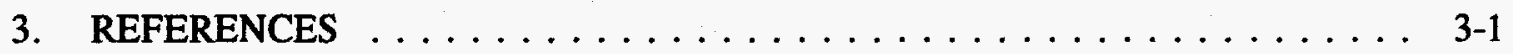


APPENDIX A: WAG 1 READINESS REVIEW CHECKLIST

APPENDIX B: WAG 1 STANDARD OPERATING PROCEDURE FOR GEOPROBE INSTALLATION AND GROUNDWATER SAMPLING

APPENDIX C: WAG 1 WELL DEVELOPMENT DATA

APPENDIX D: WAG 1 FIELD DOCUMENTATION FORMS

APPENDIX E: FIELD PROCEDURES 


\section{FIGURES}

1.1 Groundwater quality sampling and analysis activity flowchart $\ldots \ldots \ldots \ldots$ 1-16

\section{TABLES}

1.1 Groundwater level monitoring activities, purposes, and data levels . . . . . . . . 1-6

1.2 Frequencies of groundwater level monitoring at each WAG 1 location . . . . . . 1-7

1.3 Groundwater quality sampling and analyses activities and data levels . . . . . . . . . . . . . . . . . . . . . . 1-10

1.4 Sampling locations, frequencies, and analytes $\ldots \ldots \ldots \ldots \ldots \ldots \ldots \ldots$

1.5 Sample containers, preservation, and holding times for groundwater quality monitoring at WAG $1 \ldots \ldots \ldots \ldots \ldots \ldots \ldots$ 1-19

1.6 List of analytes, by location, for semiannual groundwater quality

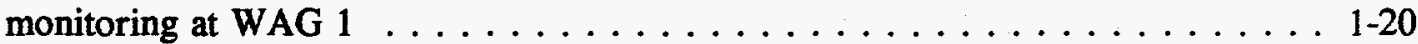

1.7 List of analytes, by location, for annual groundwater quality

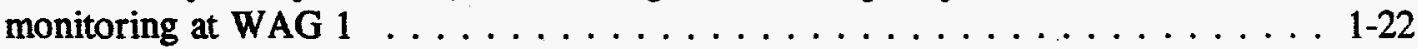

2.1 Types of WAG 1 field documentation and the information

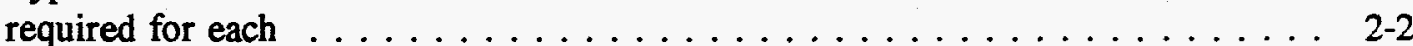





\section{ABBREVIATIONS}

$\begin{array}{ll}\text { ASTM } & \text { American Society for Testing and Materials } \\ \text { CH-8 } & \text { Corehole 8 } \\ \text { COC } & \text { chain of custody } \\ \text { DOE } & \text { U.S. Department of Energy } \\ \text { DQO } & \text { Data Quality Objective } \\ \text { Energy Systems } & \text { Martin Marietta Energy Systems, Inc. } \\ \text { EPA } & \text { U.S. Environmental Protection Agency } \\ \text { ESP } & \text { Environmental Surveillance Procedure } \\ \text { FID } & \text { flame ionization detector } \\ \text { FOF } & \text { Field Operations Facility } \\ \text { H\&S } & \text { health and safety } \\ \text { HP } & \text { Health Physics (or Physicist) } \\ \text { HSP } & \text { Health and Safety Plan } \\ \text { ID } & \text { identification } \\ \text { ORNL } & \text { Oak Ridge National Laboratory } \\ \text { OU } & \text { Operable Unit } \\ \text { PID } & \text { photoionization detector } \\ \text { PPE } & \text { personal protective equipment } \\ \text { QA } & \text { quality assurance } \\ \text { QAPP } & \text { Quality Assurance Program Plan } \\ \text { QC } & \text { quality control } \\ \text { SAP } & \text { Sampling and Analysis Plan } \\ \text { SHSO } & \text { Site Health and Safety Officer } \\ \text { STL } & \text { Sample Task Leader } \\ \text { WAG } & \text { Waste Area Grouping } \\ \text { WMP } & \text { waste management plan } \\ & \end{array}$



Waste Area Grouping (WAG) 1 at Oak Ridge National Laboratory (ORNL) includes all of the former ORNL radioisotope research, production, and maintenance facilities; former waste management areas; and some former administrative buildings. Site operations have contaminated groundwater, principally with radiological contamination. An extensive network of underground pipelines and utilities have contributed to the dispersal of contaminants to a known extent. In addition, karst geology, numerous spills, and pipeline leaks, together with the long and varied history of activities at specific facilities at ORNL, complicate contaminant migration-pathway analysis and source identification. To evaluate the extent of contamination, site characterization activity will include semiannual and annual groundwater sampling, as well as monthly water level measurements (both manual and continuous) at WAG 1. This sampling and analysis plan provides the methods and procedures to conduct site characterization for the Phase I Remedial Investigation of the WAG 1 Groundwater Operable Unit. 



\section{FIELD SAMPLING PLAN}

\subsection{INTRODUCTION}

Oak Ridge National Laboratory (ORNL), a facility owned by the U.S. Department of Energy (DOE) and operated by Martin Marietta Energy Systems, Inc. (Energy Systems), is located on DOE's Oak Ridge Reservation, about 7 miles south of the City of Oak Ridge, Tennessee. Waste Area Grouping (WAG) 1 at ORNL includes all of the former ORNL radioisotope research, production, and maintenance facilities; former waste management areas; and some former administrative buildings.

Site operations have contaminated WAG 1 groundwater, principally with radiological contamination. An extensive network of underground pipelines and utilities has contributed to the dispersal of contaminants to a known extent. In addition, karst geology, numerous spills, and pipeline leaks, together with the long and varied history of activities at specific ORNL facilities, complicate contaminant migration-pathway analysis and source identification (DOE 1994). To evaluate the extent of contamination, site characterization activity will include semiannual and annual groundwater sampling, as well as monthly water level measurements, at WAG 1.

Groundwater discharge to surface water bodies (White Oak Creek, First Creek, and Fifth Creek) may constitute a significant pathway for migration of contaminants from WAG 1 to potential off-site receptors. Investigations of groundwater flow and quality at WAG 1 conducted during Phase I of the WAG 1, Groundwater Operable Unit (OU), Remedial Investigation have shown that the flow regime is complex and that there are contaminants in the groundwater (Energy Systems 1992a). The purpose of this plan is to describe the activities for the investigation of WAG 1 hydrogeology during the Groundwater OU site characterization, to further define groundwater flow and quality.

The groundwater investigation will focus on collecting sufficient supplemental characterization data to support assessment of risk and remedial alternatives. The general objectives of the WAG 1 groundwater investigation are

- to characterize movement of groundwater through and away from WAG 1 ,

- to characterize groundwater quality in WAG 1 ,

- to investigate the interaction between surface water and groundwater and the degree of interaction among water-bearing zones,

- to identify sources of WAG 1 groundwater contamination,

- to assess the potential impact of contaminants from WAG 1 sources on potential receptors, and

- to evaluate remedial alternatives. 
This field sampling plan focuses on three activities that will support these objectives: groundwater plume characterization of Corehole $8(\mathrm{CH}-8)$, groundwater level monitoring of selected wells and piezometers, and groundwater sampling of selected wells, piezometers, sumps, manholes, and any new, proposed well/sampling locations.

This project is not mandated by the Comprehensive Environmental Response, Compensation, and Liability Act; therefore, no formalized meetings for data quality objective (DQO) development were held. Internally, DQOs were generated by the project team based on the end uses of the data to be collected.

\subsection{PROJECT MOBILIZATION}

Mobilization activities are initiated after Notice to Proceed has been granted. Various activities will be completed as part of mobilization, including the procurement of subcontractor services, procurement of equipment and supplies necessary to complete the investigation, initiation of a system for tracking and reporting the budget, project staffing, setup of a field support facility, health and safety training and ORNL-specific training, readiness review, the field planning meeting, procurement of excavation permits, and preparation of any other projectspecific documentation. Additional detail for some of these key activities is provided in the following subsections.

\subsubsection{Readiness Review}

Before implementing the field program, the Quality Assurance Project Plan, Waste Management Plan (WMP), Sampling and Analysis Plan (SAP), Health and Safety Plan (HSP), and Data Management Plan will be reviewed to identify all field activities and materials required to complete the site characterization. The review also will include identification of any spare parts required to calibrate and maintain equipment in the field. Appendix A presents a readiness review checklist showing all items and activities required to complete the program. All instruments and equipment will be checked for function and operation, and will be repaired or made ready for the field before entry into the field. In addition to these listed items, the readiness review checklist includes information on

- task deliverables,

- required approvals and permits,

- procurement of mobile laboratory and drilling subcontractor,

- personnel availability,

- training and indoctrination,

- field equipment,

- sampling equipment,

- $\quad$ site facilities and equipment, and

- health and safety (H\&S) equipment.

The readiness review checklist will be prepared and submitted to appropriate Energy Systems and DOE personnel for review before fieldwork is initiated. The readiness review will be completed no later than 1 week before the scheduled start of the investigation. An Energy 
Systems Environmental Restoration Division pre-job review also will occur before the start of fieldwork; CDM Federal will participate fully in this review.

\subsubsection{Field Planning Meeting}

The Field Task Manager will ensure that a field planning meeting occurs before work begins at the site so that all involved personnel will be informed of the requirements of project fieldwork. Additional field planning meetings will be held whenever new personnel join the field team or if the scope of work changes significantly. These meetings will encompass thorough discussions of

- objectives and scope of the fieldwork,

- project- and site-specific H\&S,

- equipment and training needs,

- field operations procedures,

- required quality control (QC) measures, and

- documents governing on-site fieldwork [see the Quality Assurance Program Plan (QAPP)].

Each meeting will have a written agenda, which will be reviewed by the Quality Assurance (QA) Specialist before the meeting. This same agenda will be issued to any field personnel joining the field team after the initial field planning meeting. When appropriate, examinations will be given at the conclusion of training modules to assess the effectiveness of training. Each attendee must sign an attendance sheet, and copies of the agenda and attendance sheet will be maintained on-site and in the project files. Depending on conditions and schedules, this meeting may take place at the field office or at another convenient location. If necessary, the agenda may be mailed or transmitted by facsimile to field personnel and discussed over the telephone before their arrival at the site.

\subsubsection{Use of the Field Operations Facility}

CDM Federal will have two trailers located at the Field Operations Facility (FOF) as its base of operations during field activities. One trailer will serve as an office, and the other will be used for storage of field equipment and supplies to ensure that they are readily available to the field crews.

\subsection{DESCRIPTION AND HISTORY OF COREHOLE 8 GROUNDWATER CONTAMINANT PLUME}

The CH-8 contaminant plume was identified in early 1992 as an apparent narrow, westwardmigrating, strike-parallel plume that discharges off WAG 1 to First Creek. Gross beta contamination levels in CH-8 are among the highest measured in WAG 1 , and ${ }^{90} \mathrm{Sr}$ contributes the majority of the beta activity. Analytical data indicate that part of the plume seeps into a storm sewer near the northeast corner of Building 2013 and discharges to First Creek via outfall 341. The plume also seeps into an abandoned storm-sewer line that parallels First Creek and discharges via outfall 342 (Energy Systems 1992b). 


\section{Site Conceptual Model}

The site conceptual model aids in understanding the suspected sources of contamination, contaminants of concern, migration pathways, and potential receptors. Data currently available from the $\mathrm{CH}-8$ area indicate groundwater contamination in the $\mathrm{CH}-8$ area to be among the highest measured in WAG 1 ; ${ }^{90} \mathrm{Sr}$ contributes the majority of the beta activity. Surface water in the area is comparatively uncontaminated, with the exception of the discharge point to First Creek. The lateral extent of the flow pathway is undetermined, but will be delineated by installing well point fences, via Geoprobe Systems technology, perpendicular to strike.

\subsection{COREHOLE 8 GROUNDWATER PLUME CHRACTERIZATION}

\subsubsection{Data Quality Objectives for CH-8 Groundwater Plume Characterization}

\section{Defining the Problem}

During $\mathrm{CH}-8$ plume characterization, the lateral extent of the plume along strike is the question to be determined.

\section{Identifying the Decision}

The decision to be made is whether to intercept the $\mathrm{CH}-8$ plume along strike.

\section{Identifying Inputs}

Inputs to the decision-making process are obtained by delineating the lateral extent and nature of contamination by installing 15 well points, via Geoprobe, in one or two fences and collecting groundwater grab samples. These data will supplement data already available, satisfy data gaps, aid the data users in determining migration pathways, and determine what remedial actions are appropriate.

\section{Defining the Study Boundaries}

The boundaries of the study will encompass the spatial area immediately west of CH-8 to nominal depths of bedrock refusal or first encountered groundwater; study depth should not exceed $20 \mathrm{ft}$.

\section{Developing a Decision Rule}

The following statement helps to define the decision rule formulated for the $\mathrm{CH}-8$ plume characterization: If the sampling event determines that gross beta activity in the stratigraphic vicinity of the $\mathrm{CH}-8$ migration stratum exists at $100 \mathrm{pCi} / \mathrm{L}$ or more, and the gross beta activity consists mostly of ${ }^{90} \mathrm{Sr}$, then the $\mathrm{CH}-8$ plume is defined, and further action (e.g., removal action) may be pursued.

\footnotetext{
'Geoprobe is a registered trademark of Geoprobe Systems, Inc., Selina, Kansas.
} 
Specifying the Limits of Decision Errors

To limit errors in the decision-making process, the data will be validated to quantify the results and rule out any error in laboratory analysis.

Optimizing the Design for Obtaining Data

A judgmental sampling approach has been designed to confirm the presence of, and to verify migratory pathways of, the contaminants of concern. Definitive data will be collected and validated.

\subsubsection{Geoprobe Installation}

The characterization of the $\mathrm{CH}-8$ plume will be accomplished by the installation and sampling of temporary well points via Geoprobe Systems technology. Fifteen Geoprobes will be installed in either one or two fences perpendicular to the plume to help characterize the lateral extent of the plume. The Geoprobe System is a hydraulic, truck-mounted system that supplies both static force and hydraulically powered percussion hammers for intrusive sampling of soil and groundwater. Geoprobes will be pushed to bedrock refusal or to groundwater, whichever is encountered first, and groundwater grab samples will be collected and analyzed according to the WAG 1 Standard Operating Procedure for Geoprobe installation and groundwater sampling (Appendix B).

\subsubsection{Geoprobe Water Sampling}

The proposed groundwater sampling activities will consist of collecting approximately 15 groundwater grab samples from Geoprobe borings, and associated QC samples, for gross alpha, gross beta, and ${ }^{90} \mathrm{Sr}$ analysis.

After the Geoprobe borings have reached refusal, an attempt will be made to collect groundwater samples. An expandable well point at the bottom of the rod string will allow groundwater to flow into the rod after the rod is pulled back. A mini-bailer, peristaltic pump, and/or a hand sampling pump will be used to collect the groundwater samples. Groundwater samples will be collected in 4-L Cubitainers ${ }^{m}$. A detailed description of the Geoprobe groundwater sampling method is located in Appendix B.

\subsection{GROUNDWATER LEVEL MONITORING OBJECTIVES}

The purpose of this section is to provide field workers with information on conducting activities that are unique and essential to accomplishing the task of groundwater level monitoring. The objective of this task is to obtain information to assess groundwater flow direction, hydraulic gradients, seasonal high and low water-table conditions, groundwater and pipeline trench interactions, and the relationship between groundwater and surface water flow regimes. Some information that is important to field workers is contained in other project-level documents. To avoid duplication of this information (which includes project-level QA/QC and H\&S protocols) other documents have been referenced as appropriate. All documents will be made available to the field workers before the initiation of field activities. Once field activities have begun, the 
field workers will carry the SAP and the QAPP to the field. The other reference documents will be available at the field office. Copies of these reference documents will be available to the field workers to carry into the field for direct reference as the need arises.

Field workers should keep these objectives in mind when conducting the activities described in this SAP. An understanding of, and a constant adherence to, the objectives of this task will ensure the collection of data in quantities and at the quality levels necessary to meet the objectives. The activities identified in Table 1.1 will be conducted to meet these objectives for groundwater level monitoring.

Table 1.1. Groundwater level monitoring activities, purposes, and data levels

\begin{tabular}{|c|c|c|c|}
\hline \multicolumn{2}{|c|}{$\begin{array}{c}\text { Groundwater level monitoring } \\
\text { activity }\end{array}$} & \multirow{2}{*}{ Activity purpose and elements } & \multirow{2}{*}{$\begin{array}{c}\text { EPA data levels } \\
\begin{array}{c}\text { Health and } \\
\text { Safety }\end{array}\end{array}$} \\
\hline 1. & $\begin{array}{l}\text { Health and safety } \\
\text { monitoring of site and } \\
\text { uncapped well }\end{array}$ & & \\
\hline 2. & $\begin{array}{l}\text { Groundwater level } \\
\text { measurements }\end{array}$ & $\begin{array}{l}\text { Assess seasonal fluctuations of the water table } \\
\text { surface during dry and wet conditions }\end{array}$ & Definitive \\
\hline 3. & $\begin{array}{l}\text { Equipment } \\
\text { decontamination }\end{array}$ & Eliminate cross-contamination between wells & $\mathrm{N} / \mathbf{A}^{a}$ \\
\hline 4. & Waste management & $\begin{array}{l}\text { Properly document and manage personal } \\
\text { protective equipment and decontamination fluid }\end{array}$ & N/A \\
\hline 5. & $\begin{array}{l}\text { Data collection and } \\
\text { management }\end{array}$ & $\begin{array}{l}\text { Properly record information in logbooks and } \\
\text { field forms, and properly download data from } \\
\text { electronic field instruments }\end{array}$ & N/A \\
\hline
\end{tabular}

- N/A = not applicable

Groundwater levels will be collected from selected wells and piezometers. The levels will be obtained using manual methods. Data from this activity will be collected on the appropriate form (see Sect. 2) and in field logbooks.

\subsubsection{Monitoring Locations and Frequencies}

Fifty-two existing groundwater monitoring wells and/or piezometers, and any new wells to be installed in 1995, will be monitored using manual methods. The locations of these wells are provided in Table 1.2, together with other site features that are relevant to the specific activity of groundwater level monitoring. 
Table 1.2. Frequencies of groundwater level monitoring at each WAG 1 location

\begin{tabular}{ccl|ccl}
\hline Location & Area & Frequency & Location & Area $^{a}$ & Frequency \\
\hline 812 & CH-8 & Monthly & 543 & 2500 & Monthly \\
560 & CH-8 & Monthly & 544 & 2500 & Monthly \\
555 & 2000 & Monthly & 577 & 2500 & Monthly \\
582 & $3001 / 3019$ & Monthly & 554 & 2500 & Monthly \\
573 & $3001 / 3019$ & Monthly & 542 & 2500 & Monthly \\
581 & $3001 / 3019$ & Monthly & 548 & 2500 & Monthly \\
603 & ORR & Monthly & 553 & 2519 & Monthly \\
607 & ORR & Monthly & 563 & 2533 sump & Monthly \\
588 & ORR & Monthly & 592 & 3500 & Monthly \\
611 & Fifth Creek & Monthly & 601 & 3500 & Monthly \\
616 & ISO & Monthly & 604 & 3500 & Monthly \\
608 & ISO & Monthly & 599 & 3500 & Monthly \\
591 & 3026 & Monthly & 600 & 3500 & Monthly \\
584 & 3026 & Monthly & 627 & 4500 & Monthly \\
590 & 3026 & Monthly & 626 & 4500 & Monthly \\
820 & SWSA 2 & Monthly & 537 & 1500 & Monthly \\
622 & SWSA 2 & Monthly & 1102 & IMP & Monthly \\
631 & SWSA 2 & Monthly & 882 & IMP & Monthly \\
634 & SWSA 2 & Monthly & 876 & IMP & Monthly \\
814 & NW & Monthly & 1103 & IMP & Monthly \\
547 & NW & Monthly & 579 & IMP & Monthly \\
545 & NW & Monthly & 874 & IMP & Monthly \\
815 & N & Monthly & 578 & STF & Monthly \\
557 & N & Monthly & 827 & SWSA 1 & Monthly \\
540 & First Creek & Monthly & 829 & SWSA 1 & Monthly \\
810 & Unit F & Monthly & 721 & SW & Monthly \\
\hline
\end{tabular}

- Abbreviations used in this table:

$\mathrm{CH}-8=$ Corehole 8

IMP $=$ Impoundments Area

ISO $=$ Isotopes Area

$\mathrm{N} \quad=$ Area north of WAG 1 boundary

$\mathrm{NW}=$ Area northwest of WAG 1 boundary

ORR = Oak Ridge Research Reactor (3042)

STF = South Tank Farm

SW $=$ Area southwest of WAG 1 boundary

SWSA $=$ Solid Waste Storage Area 


\subsubsection{Manual Water Level Measurements}

\subsubsection{Measurement guidelines}

Manual water level measurements will be obtained on a monthly basis from each of the 52 wells shown in Table 1.2. All monthly measurements must be completed in a 2 -day period. To obtain groundwater level measurements, the following equipment is required:

- personal protective equipment (PPE),

- water level indicator,

- field logbook, and

- WAG 1-Manual Water Level Measurements Form (GW-03).

The water levels will be measured to the nearest $0.01 \mathrm{ft}$ using a water level indicator according to Environmental Surveillance Procedure (ESP) 302-1. The following guidelines shall be adhered to when obtaining water level measurements.

- Don PPE as specified by the Site Health and Safety Officer (SHSO) and/or Site Health Physicist (HP).

- Remove the cap from the well.

- Have H\&S Department personnel check the atmosphere in the well casing and in the breathing zone with a photoionization detector (PID) or flame ionization detector (FID).

- If the breathing zone atmosphere is not hazardous according to the HSP, lower the water level indicator probe into the well casing. If the breathing zone is determined to be hazardous, then the site will be abandoned, the water level will not be measured, and a WAG 1-Monitoring Variance Request Form (MV-01) will be completed.

- When the alarm sounds and/or the indicator light on the side of the water level indicator reel illuminates, stop lowering the probe.

- Read the depth to water at the well casing survey mark and record it on the WAG 1-Manual Water Level Measurements Form (GW-03) and in the field logbook.

- Remove the water level indicator from the well.

\subsubsection{Decontamination}

The water level indicator must be decontaminated according to ESP-901 at the monitoring location before subsequent use. The following guidelines shall be adhered to when decontaminating the water level indicator.

- Wipe the probe and the used portion of the water level indicator line with a paper towel moistened with tap water and laboratory detergent. 
- Rinse the probe and the washed portion of the line with American Society for Testing and Materials (ASTM) Type II water.

- Allow the probe and line to air dry, or wipe them dry with a paper towel.

- Handle investigation-derived waste according to the WMP.

\subsection{GROUNDWATER QUALITY SAMPLING AND ANALYSIS OBJECTIVES}

The purpose of this section is to provide field workers with information on conducting activities that are unique and essential to accomplishing the task of groundwater quality sampling. The objective of this task is to investigate the types and range of concentrations of contaminants in the groundwater. Some information that is important to field workers is contained in other project-level documents. To avoid duplication of this information (such as project-level QA/QC and $H \& S$ protocols) other documents have been referenced as appropriate. All documents will be made available to the field workers before the initiation of field activities. Once field activities have begun, the field workers will carry the SAP and the QAPP to the field. The other reference documents will be available at the field office. Copies of these reference documents will be available to the field workers to carry into the field for direct reference as the need arises.

Field workers should keep these objectives in mind when conducting the activities described in this section. An understanding of, and a constant adherence to, the objectives of this task will ensure the collection of data in quantities and at the quality level necessary to meet the objectives. The activities identified in Table 1.3 will be conducted to meet groundwater quality monitoring objectives.

Groundwater grab samples will be collected from selected monitoring wells or locations. The samples will be obtained from the discharge of dedicated bladder pumps, a bailer, a peristaltic pump, and/or a hand sampling pump, depending on the specific characteristics of each well or location. The discharge will be collected directly into the sample containers. Data from these activities will be collected on the appropriate forms (see Sect. 2) and in field logbooks. After the samples have been collected, they will be packaged and shipped to a laboratory for analysis.

\subsubsection{Data Quality Objectives for Groundwater Sampling}

\section{Defining the Problem}

Multiple localized areas of WAG 1 exhibit groundwater contamination. The available data are insufficient to determine the extent of this contamination, to describe likely migration pathways, or to describe changing conditions. Baseline monitoring data are not being collected in support of planned remedial actions for other OUs in WAG 1.

\section{Identifying the Decision}

The decisions to be made for WAG 1 groundwater are (1) whether localized areas of contamination exist that are currently or potentially developing into release locations that would 
Table 1.3. Groundwater quality sampling and analyses activities and data levels

Groundwater quality sampling and analysis activity

Activity purpose and elements

Ensure worker health and safety

1. Health and Safety monitoring of site and wells

2. Groundwater level measurements

3. Monitoring well purging (indicator parameters)

4. Groundwater sample collection and analysis

5. Equipment decontamination

6. Waste management

7. Data collection and management
Assess seasonal fluctuations of the water table surface during dry and wet conditions

Purge well for sample collection

$\bullet$ Confirm contaminants of concern

- Perform groundwater geochemistry characterization

- Estimate flow directions and rates

- Perform risk calculations

- Evaluate remedial alternatives

Eliminate cross-contamination between wells

Properly document and manage personal protective equipment, purge water, and decontamination fluids

- Properly record information in logbooks and field forms

- Properly download data for data validation
EPA data levels

Health and Safety

Definitive

Screening

Definitive

Definitive

Not applicable

Not applicable

Not applicable 
require prioritized action (e.g., a removal action), and (2) how groundwater contamination levels in the vicinity of planned remedial action OUs would be affected by those remediation efforts.

\section{Identifying Inputs}

Inputs to the decision-making process include groundwater elevation and quality data.

\section{Defining the Study Boundary}

The study area is limited to the spatial boundaries of WAG 1, and to a maximum depth of $50 \mathrm{ft}$. The study is further delineated by its scheduled temporal and seasonal limits.

\section{Developing a Decision Rule}

The following statements help to define the decision rule for WAG 1 groundwater.

- If results from two seasonally consecutive sampling events exhibit a nominal order-ofmagnitude change above similar seasonal historical results, and the location is remote from an operational remedial action, then changing conditions may be concluded, and further action (e.g., a removal action) should be pursued.

- If results from two seasonally consecutive sampling events exhibit a nominal order-ofmagnitude change below similar seasonal historical results, and the location is remote from an operational remedial action, then changing conditions may be concluded, and monitoring should be continued.

- If results from two seasonally consecutive sampling events exhibit a nominal order-ofmagnitude change below similar seasonal historical results, and the location is sufficiently near an operational remedial action, then positive impact on groundwater by the remedial action may be concluded, and monitoring should be continued.

- If results from two seasonally consecutive sampling events exhibit a nominal order-ofmagnitude change above similar seasonal historical results, and the location is sufficiently near an operational remedial action, then negative impact on groundwater by the remedial action may be concluded, monitoring should be continued, and further action (e.g., a removal action) should be pursued.

- If results from two seasonally consecutive sampling events are within the variability band of all historical events from the same season, then static conditions may be concluded, and a reduction in monitoring frequency should be considered.

\subsubsection{Sampling Locations, Frequencies, and Analytes}

Forty-four groundwater monitoring wells/piezometers will be sampled for various analytes on a semiannual or annual frequency. The locations of all 44 wells, together with other site features that are relevant to groundwater sampling, are shown on the WAG 1 Sample Location map (which will be available at the FOF). 
Table 1.4 provides the location, area, parameters to be sampled for at each location, and sampling frequency for the $\mathbf{4 4}$ wells/piezometers to be sampled. Corresponding notes are provided for each location that explain why it is being sampled as part of this activity.

Preservation methods, holding times, storage conditions, and container materials will be determined according to ESP-701. The cleaning and decontaminating of sampling containers and sampling devices will be determined according to ESP-900.

\subsubsection{Groundwater Level Measurements}

A flowchart of the tasks to be conducted as part of this activity is displayed in Fig. 1.1. This flowchart graphically depicts the sequence in which the tasks will be conducted, the decision points associated with conducting the tasks, and when information will be recorded on the forms for data collection and management.

Groundwater levels will be measured in each monitoring well before the well is purged. The objective for obtaining water level measurements is to determine the appropriate quantity of water to be purged from the well before sampling. To obtain groundwater level measurements, the following equipment is required:

- surgical gloves and other appropriate PPE as specified by the SHSO and/or Site HP,

- PID or FID,

- water level indicator,

- field logbook, and

- WAG 1-Well Purging and Sampling Form (GWQ-01).

The water levels will be measured to the nearest $0.01 \mathrm{ft}$ using a water level indicator in accordance with ESP 302-1. The following guidelines will be adhered to when obtaining water level measurements.

- Don PPE as required.

- Remove the cap from the well and allow it to vent for 3 to $5 \mathrm{~min}$.

- Check ambient air with a PID or FID; note reading.

- Check the atmosphere at the top of the well casing and the breathing zone with a PID or FID according to guidance in the HSP.

- If contaminant levels in breathing zone atmosphere are not above ambient levels, lower the water level indicator probe into the well casing. If contaminant levels in breathing zone atmosphere are above ambient levels, the SHSO will contact the Industrial Hygiene Department and work will stop at that location. 


\begin{tabular}{|c|c|c|c|c|}
\hline Location ${ }^{a, b}$ & Area $^{a}$ & Parameters, ${ }^{a, c}$ & $\begin{array}{l}\text { Frequency } \\
\text { (per year) }\end{array}$ & Notes $^{a}$ \\
\hline 830 & 2500 & Tritium & 2 & ILW leak \\
\hline 553 & 2519 & Metals, BTEX, TPH & 2 & Diesel UST, high metals concentrations \\
\hline 2531 sump & 2533 sump & Alpha, beta, tritium & 2 & 2533 sump plume monitoring \\
\hline 2533 sump & 2533 sump & Alpha, beta, tritium & 2 & 2533 sump plume; LLW leak \\
\hline 567 & 2533 sump & Alpha, beta, tritium & 1 & 2533 sump plume monitoring \\
\hline 564 & 2533 sump & Alpha, beta, tritium & 2 & 2533 sump plume monitoring \\
\hline 566 & 2533 sump & Alpha, beta, tritium & 2 & 2533 sump plume monitoring \\
\hline SB132 & $3001 / 3019$ & Alpha, beta, tritium, isotopics & 2 & LLW leak; CH-8 source investigation \\
\hline 584 & 3026 & Alpha, beta, tritium & 2 & LLW leaks; high alpha and beta levels \\
\hline 590 & 3026 & Alpha, beta, tritium & 2 & Leaks/spills from 3024,3026 , WC-4 \\
\hline 601 & 3500 & Alpha, beta, tritium, mercury & 2 & Elevated rad; mercury from 3503 \\
\hline 599 & 3500 & VOCs & 2 & Elevated VOCs \\
\hline 593 & 3525 & Alpha, beta & 1 & Monitor elevated alpha and beta \\
\hline 824 & WOC & Mercury & 2 & Mercury from 4501 and/or 4508 \\
\hline $\mathrm{CH}-8: 2$ and $3^{d}$ & CH-8 & Alpha, beta, tritium, isotopics & 2 & $\mathrm{CH}-8$ plume investigation \\
\hline 812 & $\mathrm{CH}-8$ & Alpha, beta, tritium, isotopics & 2 & $\mathrm{CH}-8$ plume monitoring \\
\hline 535 & CH-8 & Alpha, beta, tritium, isotopics & 2 & CH-8 plume underflow of First Creek \\
\hline 539 & $\mathrm{CH}-8$ & Alpha, beta, tritium, isotopics & 2 & CH-8 plume monitoring \\
\hline 874 & IMP & Alpha, beta, tritium & 2 & Rad monitoring downgradient of impoundments \\
\hline 875 & IMP & Alpha, beta, tritium & 2 & Rad monitoring downgradient of impoundments \\
\hline
\end{tabular}




\begin{tabular}{|c|c|c|c|c|}
\hline Location $^{a, b}$ & Area $^{a}$ & Parameters $^{a_{1} c}$ & $\begin{array}{l}\text { Frequency } \\
\text { (per year) }\end{array}$ & Notes $^{a}$ \\
\hline 885 & IMP & Alpha, beta, tritium & 2 & Rad monitoring downgradient of impoundments \\
\hline 876 & IMP & Alpha, beta, tritium & 2 & Rad monitoring downgradient of impoundments \\
\hline 1102 & IMP & Alpha, beta, tritium & 2 & Rad monitoring downgradient of impoundments \\
\hline 1103 & IMP & Alpha, beta, tritium & 2 & Rad monitoring downgradient of impoundments \\
\hline 1104 & IMP & Alpha, beta, tritium & 2 & Rad monitoring downgradient of impoundments \\
\hline SB189 & IMP & Alpha, beta, tritium, isotopics & 1 & Confirm high beta and ${ }^{63} \mathrm{Ni}$ \\
\hline 598 & ISO & Alpha, beta, tritium, isotopics, VOCs & 2 & Monitor elevated rad and VOCs; confirm ${ }^{63} \mathrm{Ni}$ \\
\hline 3033 sump & ISO & Alpha, beta, tritium, isotopics & 2 & Source investigation \\
\hline MH114 & ISO & Alpha, beta, tritium, isotopics, BTEX, TPH & 2 & Source investigation \\
\hline MH233 & ISO & Alpha, beta, tritium, isotopics, BTEX, TPH & 2 & Source investigation \\
\hline Stockdale CH33 & ISO & Alpha, beta, tritium, isotopics & 2 & Source investigation; underflow of Fifth Creek \\
\hline 549 & NW & Alpha, beta, tritium, isotopics, metals, VOCs & 1 & Monitor elevated rad, metals, and VOCs \\
\hline 538 & NW & Alpha, beta, tritium, metals, VOCs & 1 & Monitor elevated rad, metals, and VOCs \\
\hline 547 & NW & Alpha, beta, tritium, metals, VOCs & 1 & Monitor elevated rad, metals, and VOCs \\
\hline 3042 sump & ORR & Alpha, beta, tritium, isotopics, BTEX, TPH & 2 & $\begin{array}{l}\text { Confirm groundwater rad contamination; source } \\
\text { investigation }\end{array}$ \\
\hline 571 & SWSA 1 & Alpha, beta, tritium, isotopics & 2 & Monitor possible contamination migration \\
\hline 622 & SWSA 2 & Alpha, beta, tritium & 2 & Monitor possible contamination migration \\
\hline 4501 sumps (4) & 4501 & Mercury & 2 & Monitor mercury contamination \\
\hline
\end{tabular}


Table 1.4 (continued)

\begin{tabular}{lllll}
\hline Location $^{a, b}$ & Area $^{a}$ & Parameters $^{a, c}$ & $\begin{array}{c}\text { Frequency } \\
\text { per year) }^{\text {p }}\end{array}$ & Notes $^{a}$ \\
\hline 559 & 3108 & BTEX, TPH, alpha, beta, tritium & 2 & Petroleum UST; monitor rad \\
555 & 2026 & BTEX, TPH, alpha, beta, tritium & 2 & Petroleum UST; monitor rad \\
581 & 3002 & BTEX, TPH, alpha, beta, tritium & 2 & Petroleum UST; monitor rad \\
583 & NTF & BTEX, TPH, alpha, beta, tritium & 2 & Petroleum UST; monitor rad \\
600 & 3598 & BTEX, TPH, alpha, beta, tritium & 2 & Petroleum UST; monitor rad \\
614 & 3027 & BTEX, TPH, alpha, beta, tritium & 2 & Petroleum UST; monitor rad \\
\hline
\end{tabular}

"Abbreviations used in this table:

BTEX = Benzene, toluene, ethylbenzene, $x y l e n e s$

ILW = Intermediate-level waste

IMP $=$ Impoundments Area

ISO = Isotopes Area

LLW = Low-level waste

NTF $=$ North Tank Farm

$\mathrm{NW}=$ Area northwest of WAG 1 boundary
$\mathrm{ORR}=$ Oak Ridge Research Reactor (3042)

SWSA $=$ Solid Waste Storage Area

TPH $=$ Total petroleum hydrocarbons
UST $=$ Underground storage tank
VOC $=$ Volatile organic compound
SB $=$ Soil boring
CH-8 $=$ Corehole 8
MH $=$ Manhole
Rad $=$ Radioactivity

- This list is complete except for new, proposed sampling/well locations that may be included at a future date.

- Total suspended solids will be sampled for at every location.

\& $\mathrm{CH}-8$ will be monitored in intervals and sampled in accordance with Westbay specifications. 

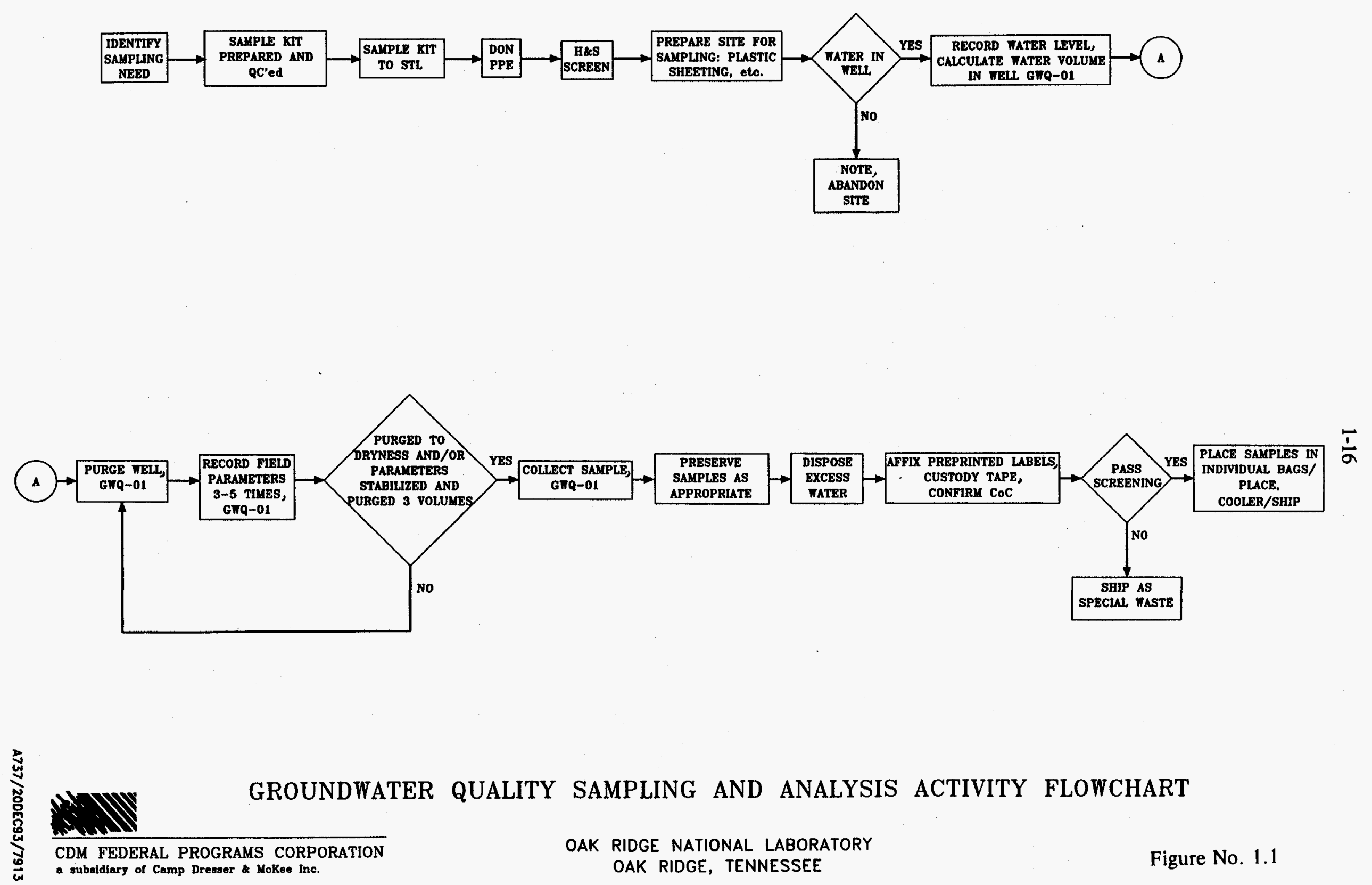

R QUALITY SAMPLING AND ANALYSIS ACTIVITY FLOWCHART

CDM FEDERAL PROGRAMS CORPORATION

OAK RIDGE NATIONAL LABORATORY

OAK RIDGE, TENNESSEE

Figure No. 1.1 
- When the alarm sounds and/or the indicator light on the side of the water level indicator reel illuminates, stop lowering the probe.

- Read the depth to water at the well casing survey mark and record it on the WAG 1-Well Purging and Sampling Form (GWQ-01) and in the field logbook.

- Remove the water level indicator from the well, wiping the tape clean as it is retrieved.

The water level indicator must be decontaminated at the site according to ESP-901 before subsequent use. The following guidelines shall be adhered to when decontaminating the water level indicator.

- Wipe the probe and the used portion of the water level indicator line with a paper towel moistened with distilled water and laboratory detergent.

- Rinse the probe and the washed portion of the line with distilled water.

- Allow the probe and line to air dry, or wipe dry with a paper towel.

\subsubsection{Monitoring Well Purging}

Groundwater monitoring wells will be purged and field parameters (i.e., pH, temperature, turbidity, and conductivity) will be measured before obtaining samples. The objective for obtaining the field parameters and purging the monitoring wells is to ensure that fresh formation water is present in the wells during sampling.

Monitoring wells will be purged according to ESP 302-2. Measurements of the field parameters will be obtained in each well before sample collection according to ESP 307-2, ESP 307-1, and ESP-307-8. To purge the wells and measure the field parameters, the following equipment is required:

- surgical gloves and other appropriate PPE,

- displacement bladder pump or alternate method (e.g., peristaltic pump, bailer, etc.),

- 26-L Carboy,

- 32-gal trash can,

- large plastic trash bag(s),

- 55-gal drum(s),

- HORIBA Water Quality Checker (or equivalent),

- field logbook, and

- WAG 1-Well Purging and Sampling Form (GWQ-01).

The total volume of water to be purged, which is dependent upon the total depth of the well and the water level, will be determined according to ESP 302-2. The following guidelines shall be adhered to when determining the total volume of water to be purged from the wells.

- Subtract the water level from the total depth of the well to obtain the height of the water column. 
- Multiply the height of the water column by the appropriate gal/ft multiplier on the WAG 1-Well Purging and Sampling Form (GWQ-01) to obtain the volume (in gal) of water present in the well casing.

- Multiply the volume of water present in the well casing by three well volumes to obtain the total volume of water to be purged from the well.

While purging the well, measurements of $\mathrm{pH}$, temperature, turbidity, and conductivity will be obtained using a HORIBA Water Quality Checker or equivalent. Well development data is provided in Appendix C. The field parameter measurements will be obtained according to the following guidelines. Before obtaining the parameter measurements, the HORIBA Water Quality Checker (or equivalent instrument) will be calibrated according to manufacturer specifications.

- Measure field parameters ( $\mathrm{pH}$, temperature, turbidity, and conductivity) while the water is being purged from the well, and record after each purge volume.

- Immerse the appropriate parameter probe into a sample of the well purge water.

- Obtain the parameter value from the readout of the field measurement instrument.

- Record the obtained parameter value on the WAG 1-Well Purging and Sampling Form (GWQ-01) and in the field logbook.

\subsubsection{Groundwater Sampling}

Groundwater samples will be collected as grab samples from each of the selected monitoring wells. A list of sample containers, preservatives, and holding times for groundwater quality monitoring in WAG 1 is provided in Table 1.5. Analytes to be sampled for at each location during the semiannual and annual sampling events are listed in Tables 1.6 and 1.7, respectively. While sampling the well, measurements of $\mathrm{pH}$, temperature, turbidity, and conductivity will be taken with a HORIBA Water Quality Checker (or equivalent). These parameters will be measured again at the conclusion of sampling. To collect groundwater samples, the following equipment is required:

- $\quad$ surgical gloves and other appropriate PPE;

- plastic sheeting;

- sample containers, prewashed;

- sample labels;

- HORIBA Water Quality Checker (or equivalent);

- bar coding equipment;

- displacement bladder pump or alternate method (e.g., peristaltic pump, bailer, etc.);

- sample containment cooler;

- ice;

- WAG 1-Well Purging and Sampling Form (GWQ-01);

- sample preservatives;

- sample bags;

- field logbook;

- chain-of-custody form (see Appendix D); 


\begin{tabular}{|c|c|c|c|c|c|}
\hline Parameter ${ }^{a}$ & Analytical methods & Container type ${ }^{a}$ & Container volume & Preservative & Maximum holding time \\
\hline Tritium & EPA 900 & $\mathbf{P}$ & $250 \mathrm{~mL}$ & $4^{\circ} \mathrm{C}$ & 180 days \\
\hline Gross alpha & SW 846/9310 & Q & $4 \mathrm{~L}$ & $\mathrm{HNO}_{3}, \mathrm{pH}<2$ & 180 days \\
\hline Gross beta & SW 846/9310 & $Q$ & $4 \mathrm{~L}$ & $\mathrm{HNO}_{3}, \mathrm{pH}<2$ & 180 days \\
\hline Isotopes $^{b}$ & EPA 900/HASL-300 & $\mathbf{Q}$ & $4 \mathrm{~L}$ & $\mathrm{HNO}_{3}, \mathrm{pH}<2$ & 180 days \\
\hline BTEX & SW 8020 & G vial, T-lined & $40 \mathrm{~mL}$ & $\mathrm{HCl}, \mathrm{pH}<2,4^{\circ} \mathrm{C}$ & 14 days \\
\hline TCL VOCs & CLP & G vial, $T$-lined & $40 \mathrm{~mL}$ & $\mathrm{HCl}, \mathrm{pH}<2,4^{\circ} \mathrm{C}$ & 14 days \\
\hline TPH & SW & G vial, $\mathbf{T}$-lined & $1 \mathrm{~L}$ & $4^{\circ} \mathrm{C}$ & 28 days \\
\hline Metals & CLP & $\mathbf{P}$ & $1 \mathrm{~L}$ & $\mathrm{HNO}_{3}, \mathrm{pH}<2$ & 6 months \\
\hline Mercury & CLP & $\mathbf{P}$ & $250 \mathrm{~mL}$ & $\mathrm{HNO}_{3}, \mathrm{pH}<2$ & 28 days \\
\hline TSS & EPA 160.2 & $\mathbf{P}$ & $1 \mathrm{~L}$ & $4^{\circ} \mathrm{C}$ & 7 days \\
\hline
\end{tabular}

- Abbreviations used in this table:

BTEX = Benzene, toluene, ethylene, and xylenes

CLP = Contract Laboratory Program

EPA $=$ U.S. Environmental Protection Agency

$\mathbf{G}=$ Glass

HASL = Health and Safety Laboratory

$\mathbf{P}=$ High-density polyethylene

$Q=$ Cubitainer

SW = Solid Waste

$\mathbf{T}=$ Teflon

TCL $=$ Target Compound List

TPH $=$ Total petroleum hydrocarbons

TSS $=$ Total suspended solids

VOC $=$ volatile organic compound

b Isotopes = ${ }^{90} \mathrm{Sr},{ }^{137} \mathrm{Cs},{ }^{147} \mathrm{Pm},{ }^{226} \mathrm{Ra},{ }^{228} \mathrm{Ra},{ }^{99} \mathrm{Tc},{ }^{234} \mathrm{U},{ }^{235} \mathrm{U},{ }^{236} \mathrm{U},{ }^{238} \mathrm{U},{ }^{226} \mathrm{Th},{ }^{232} \mathrm{Th},{ }^{63} \mathrm{Ni}$, and ${ }^{60} \mathrm{Co}$ 
Table 1.6. List of analytes, by location, for semiannual groundwater quality monitoring at WAG 1

\begin{tabular}{|c|c|c|c|c|c|c|c|c|c|c|c|}
\hline Location & $\begin{array}{l}\text { CLP } \\
\text { VOCs }\end{array}$ & Isotopes & BTEX $^{a}$ & $\begin{array}{c}\text { CLP } \\
\text { metals }^{a}\end{array}$ & $\begin{array}{l}\text { Gross } \\
\text { alpha }\end{array}$ & $\begin{array}{c}\text { Gross } \\
\text { beta }\end{array}$ & ${ }^{3} \mathrm{H}$ & $\mathrm{TPH}^{a}$ & Mercury & TSS $^{a}$ & $\begin{array}{l}\text { Field quality } \\
\text { control samples }\end{array}$ \\
\hline 830 & & & & & & & $\mathbf{X}$ & & & $\mathbf{X}$ & Trip blank \\
\hline 553 & & & $\mathbf{x}$ & $\mathbf{X}$ & & & & $\mathrm{X}$ & & $\mathbf{X}$ & Trip blank \\
\hline 2531 sump & & & & & $\mathbf{X}$ & $\mathbf{X}$ & $\mathbf{x}$ & & & $\mathbf{X}$ & Trip blank \\
\hline 2533 sump & & & & & $\mathbf{X}$ & $\mathbf{X}$ & $\mathbf{x}$ & & & $\mathbf{X}$ & Trip blank \\
\hline 564 & & & & & $\mathbf{X}$ & $\mathbf{X}$ & $\mathbf{x}$ & & & $\mathbf{X}$ & Trip blank \\
\hline 566 & & & & & $\mathbf{X}$ & $\mathbf{X}$ & $\mathbf{x}$ & & & $\mathbf{X}$ & Trip blank \\
\hline SB132 & & $\mathbf{x}$ & & & $\mathbf{X}$ & $\mathrm{X}$ & $\mathbf{x}$ & & & $\mathbf{X}$ & Trip blank \\
\hline 584 & & & & & $\mathbf{X}$ & $\mathbf{x}$ & $\mathbf{x}$ & & & $\mathbf{X}$ & Trip blank \\
\hline 590 & & & & & $\mathbf{x}$ & $\mathbf{X}$ & $\mathrm{X}$ & & & $\mathbf{X}$ & Trip blank, duplicate \\
\hline 601 & & & & & $\mathbf{X}$ & $\mathbf{X}$ & $\mathbf{x}$ & & $\mathbf{X}$ & $\mathbf{X}$ & Trip blank, spike(s) \\
\hline 599 & $\mathbf{x}$ & & & & & & & & & $\mathrm{X}$ & Trip blank \\
\hline 824 & & & & & & & & & $\mathbf{X}$ & $\mathbf{X}$ & Trip blank \\
\hline CH-8 & & $\mathrm{X}$ & & & $\mathbf{X}$ & $\mathbf{x}$ & $\mathbf{X}$ & & & $\mathbf{X}$ & Trip blank \\
\hline 812 & & $\mathbf{X}$ & & & $\mathbf{x}$ & $\mathrm{X}$ & $\mathbf{x}$ & & & $\mathrm{X}$ & Trip blank \\
\hline 535 & & $\mathbf{X}$ & & & $\mathbf{X}$ & $\mathbf{x}$ & $\mathbf{x}$ & & & $\mathrm{X}$ & Trip blank \\
\hline 539 & & $\mathrm{X}$ & & & $\mathbf{X}$ & $\mathrm{X}$ & $\mathbf{X}$ & & & $\mathrm{X}$ & Trip blank, duplicate \\
\hline 874 & & & & & $\mathbf{x}$ & $\mathbf{x}$ & $\mathbf{x}$ & & & $\mathrm{X}$ & Trip blank \\
\hline 875 & & & & & $\mathrm{X}$ & $\mathbf{x}$ & $\mathrm{X}$ & & & $\mathrm{X}$ & Trip blank \\
\hline 885 & & & & & $\mathbf{X}$ & $\mathrm{X}$ & $\mathrm{x}$ & & & $\mathrm{X}$ & Trip blank \\
\hline 876 & & & & & $\mathbf{x}$ & $\mathbf{x}$ & $\mathbf{X}$ & & & $\mathrm{X}$ & Trip blank \\
\hline 1102 & & & & & $\mathrm{X}$ & $\mathrm{x}$ & $\mathrm{x}$ & & & $\mathrm{X}$ & Trip blank \\
\hline 1103 & & & & & $\mathrm{X}$ & $\mathrm{X}$ & $\mathrm{x}$ & & & $\mathrm{X}$ & Trip blank \\
\hline
\end{tabular}


Table 1.6 (continued)

\begin{tabular}{|c|c|c|c|c|c|c|c|c|c|c|c|}
\hline Location & $\begin{array}{c}\text { CLP } \\
\text { VOCs }^{n}\end{array}$ & Isotopes & BTEX $^{a}$ & $\begin{array}{c}\text { CLP } \\
\text { metals }\end{array}$ & $\begin{array}{l}\text { Gross } \\
\text { alpha }\end{array}$ & $\begin{array}{l}\text { Gross } \\
\text { beta }\end{array}$ & ${ }^{3} \mathrm{H}$ & TPH $^{a}$ & Mercury & TSS $^{a}$ & $\begin{array}{l}\text { Field quality } \\
\text { control samples }\end{array}$ \\
\hline 1104 & & & & & $\mathbf{x}$ & $\mathbf{x}$ & $\mathbf{x}$ & & & $\mathbf{x}$ & Trip blank \\
\hline 3033 sump & & $\mathbf{x}$ & & & $\mathrm{x}$ & $\mathrm{X}$ & $\mathrm{x}$ & & & $\mathrm{x}$ & Trip blank \\
\hline MH114 & & $\mathrm{x}$ & $\mathrm{x}$ & & $\mathbf{x}$ & $\mathbf{x}$ & $\mathbf{x}$ & $\mathbf{x}$ & & $\mathbf{x}$ & Trip blank, duplicate \\
\hline 3042 sump & & $\mathbf{X}$ & $\mathbf{X}$ & & $\mathrm{X}$ & $\mathrm{X}$ & $\mathbf{X}$ & $\mathrm{X}$ & & $\mathbf{x}$ & Trip blank, spike(s) \\
\hline 571 & & $\mathrm{X}$ & & & $\mathrm{x}$ & $\mathbf{x}$ & $\mathbf{X}$ & & & $\mathrm{X}$ & Trip blank \\
\hline 622 & & & & & $\mathbf{x}$ & $\mathrm{X}$ & $\mathbf{X}$ & & & $\mathrm{x}$ & Trip blank \\
\hline 4501 sump & & & & & & & & & $\mathrm{X}$ & $\mathrm{x}$ & Trip blank \\
\hline 583 & & & $\mathbf{x}$ & & $\mathrm{X}$ & $\mathrm{X}$ & $\mathbf{X}$ & $\mathrm{x}$ & & $\mathrm{X}$ & Trip blank \\
\hline 600 & & & $\mathrm{x}$ & & $\mathbf{x}$ & $\mathrm{x}$ & $\mathrm{x}$ & $\mathrm{x}$ & & $\mathrm{x}$ & Trip blank, duplicate \\
\hline 614 & & & $\mathrm{x}$ & & $\mathbf{x}$ & $\mathbf{X}$ & $\mathbf{X}$ & $\mathbf{X}$ & & $\mathrm{X}$ & Trip blank \\
\hline
\end{tabular}

${ }^{a}$ Abbreviations used in this table: BTEX $=$ Benzene, toulene, ethylene, and xylenes

$$
\begin{aligned}
& \text { CLP }=\text { Contract Laboratory Program } \\
& \mathrm{TPH}=\text { Total petroleum hydrocarbons } \\
& \text { TSS }=\text { Total suspended solids } \\
& \text { VOC }=\text { Volatile organic compound }
\end{aligned}
$$

${ }^{b}$ Equipment rinseates will be collected at a frequency of $10 \%$. 


\begin{tabular}{|c|c|c|c|c|c|c|c|c|}
\hline Location $^{a}$ & $\begin{array}{c}\text { CLP } \\
\text { VOCs }^{b}\end{array}$ & Isotopes & CLP metals ${ }^{b}$ & Gross alpha & Gross beta & ${ }^{3} \mathrm{H}$ & TSS $^{b}$ & $\begin{array}{c}\text { Field quality } \\
\text { control samples }\end{array}$ \\
\hline 567 & & & & $\mathrm{X}$ & $X$ & $\mathbf{X}$ & $X$ & $\begin{array}{l}\text { Trip blank, } \\
\text { duplicate }\end{array}$ \\
\hline 593 & & & & $\mathbf{X}$ & $\mathbf{X}$ & $\mathbf{X}$ & $\mathbf{X}$ & $\begin{array}{l}\text { Trip blank, } \\
\text { spike }\end{array}$ \\
\hline SB189 & & $\mathbf{X}$ & & $\mathbf{X}$ & $\mathbf{x}$ & $\mathbf{x}$ & $\mathrm{X}$ & Trip blank \\
\hline 549 & $\mathbf{X}$ & $\mathbf{X}$ & $\mathbf{X}$ & $\mathrm{X}$ & $\mathbf{X}$ & $\mathbf{x}$ & $\mathrm{X}$ & Trip blank \\
\hline 538 & $\mathbf{X}$ & & $\mathrm{X}$ & $\mathbf{X}$ & $\mathbf{X}$ & $\mathrm{X}$ & $\mathrm{X}$ & Trip blank \\
\hline 547 & $\mathbf{X}$ & & $\mathbf{X}$ & $\mathbf{X}$ & $\mathbf{X}$ & $\mathbf{x}$ & $\mathbf{X}$ & Trip blank \\
\hline
\end{tabular}

a This list is complete except for new, proposed sampling/well locations that may be included at a future date

b Abbreviations used in this table: $\quad$ CLP $=$ Contract Laboratory Program

TSS $=$ Total suspended solids

VOC $=$ Volatile organic compound

c One equipment rinseate is to be collected. 
- custody seals; and

- in-line $0.45-\mu \mathrm{m}$ filters.

Groundwater samples will be collected in accordance with the appropriate ESPs (i.e., ESP 302-3 and ESP 302-5) based on well-specific characteristics (that is, wells will be sampled using a bladder pump, a bailer, a peristaltic pump, etc).

The following guidelines should be followed when collecting groundwater samples.

- Don PPE as required by the SHSO before beginning work.

- Collect groundwater samples in the sample container directly from the sampling device.

- Measure field parameters ( $\mathrm{pH}$, temperature, conductivity, and turbidity) periodically during sample collection.

- Complete the well purging and sampling summary form and sample labels in the field while working. Samples will be labeled in accordance with WAG 6-FOP 9 (included in Appendix E).

- Measure field parameters ( $\mathrm{pH}$, temperature, conductivity, and turbidity) at completion of sample collection.

- Filter the samples to be analyzed for gross alpha, total radioactive strontium, gamma radiation, and tritium in the field if possible. If the samples are not filtered in the field, they will be filtered in the laboratory.

- Add the appropriate preservatives to the samples if the sample containers are not prepreserved (see Table 1.5).

- Place the samples in an insulated cooler containing ice, and transport them to the appropriate location for packaging and shipping.

- Complete chain-of-custody forms and submit the samples to the appropriate analytical chemistry laboratory for analysis.

In some cases, the volume of groundwater in a well may not be sufficient to obtain the desired number of samples. In these cases, sample collection priority will be as listed from left to right in Tables 1.6 and 1.7. 


\section{DATA MANAGEMENT FOR FIELD ACTIVITIES}

\subsection{INTRODUCTION}

Careful data management is essential to achieving the objectives of the WAG 1, Groundwater $\mathrm{OU}$, site characterization. To ensure that data are managed properly, the project team will implement a system of field and laboratory documentation designed to help ensure accurate and complete data recording. The system, described in this section, employs bar coded forms used in sequence to manually record groundwater sampling and monitoring data. These forms and other field documentation will provide data and information of the appropriate quality to meet project DQOs.

\subsection{FIELD DOCUMENTATION}

Field documentation shall consist of

- one master site logbook (to be maintained at field headquarters),

- an equipment maintenance and calibration logbook,

- an activity-specific field logbook,

- a telephone logbook,

- project- and activity-specific field forms (see Appendix D), and

- bar code labels.

All documentation must be completed in waterproof black ink, and corrections must be marked through with a single line, dated, and initialed. Handwritten documents must be legible. Table 2.1 displays where, and what kind of, information must be recorded.

\section{Field Documentation Forms}

Field documentation forms will be the primary documentation of all field activities. The following forms are to be used for the specific activities addressed in this SAP:

- WAG 1-Manual Water Level Measurements Form (GW-03),

- WAG 1-Well Purging and Sampling Form (GWQ-01),

- WAG 1-Record of Repair Form (RF-01),

- WAG 1-Monitoring Variance Request Form (MV-01),

- WAG 1-Weekly Activity Schedule (WAS-01),

- WAG 1-Field Collection Task Map (FCTM-01),

- WAG 1-Field Activity Sheet (FAS-01), and

- WAG 1-Chain-of-Custody Form (COC-01).

These forms are located in Appendix D.

The data management team will create "Blank Form Books" filled with previously bar coded forms to be used by the field teams. Each type of form will be stored in a separate binder, and each form will have a sequentially numbered bar code preattached to its bottom right corner. A 
Table 2.1. Types of WAG 1 field documentation and the information required for each

Field documentation Information

Site Logbook

Equipment

Maintenance and

Calibration Logbook

Field Logbooks

Telephone Logbook

Vehicle Logbook
- A list of all field logbooks;

- daily temperature, weather conditions, and names and titles of personnel present;

- name, title, organization, and purpose of site visitors;

- outline of daily field activities;

- problems, their final resolution, and anticipated impact on the field investigation;

- field changes or variances.

- a record of samples collected and shipped; and

- a record of equipment decontamination.

- Equipment name, serial number, and identification (ID) number;

- date of each calibration event;

- identity of person performing calibration; and

- calibration settings and values.

- Date and time task started; weather conditions; and names, titles, and organizations of personnel performing the task;

- a description of site activities in specific detail;

- a description, in detail, of any field test(s) (and results);

- a description of environmental and QC samples collected;

- a list of the time, equipment type and serial or ID number, and procedure followed for decontamination activities;

- a list of equipment failures or breakdowns; and

- a description of calibration activities in the field.

- Date of call,

- time of call,

- whether incoming or outgoing,

- participating parties, and

- subject and pertinent information.

- Daily mileage $\log$ and

- maintenance check records. 
copy of the appropriate form will be inserted on the outside cover of the "Blank Form Book," and the binder will bear the form number. The form bar code label will be entered into the bar code reader for scanning by the Sample Task Leader when the data on the form are uploaded to the data base. If that form is not used after being taken to the field, the Sample Task Leader will return the blank form to the notebook for use on another day.

The form bar code label will be attached to the bottom right corner of the form and also entered into the field logbook. Any information pertinent to the current field activity or field condition that is not requested on the field documentation form should be entered in the "Comments" section of the form and also in the field logbook. Any charts, oversize pages, and other printed material (e.g., runoff hydrographs, sample times) pertinent to current field activities will be securely attached to the corresponding field documentation form. The form number of the corresponding field documentation form must be written somewhere on the attached material and contained in the notebook. When the Sample Task Leader returns to the FOF at the end of the day, the forms will be given to the Field Task Manager to review. The Field Task Manager will review the forms and forward them to the Data Manager for entry into the data base.

The form bar code numbers must be used in sequence for record keeping purposes. The form bar code numbers will serve as identifiers for location of the forms in the files. Each day, the completed forms will be forwarded to the Field Task Manager for review. The Field Task Manager will give all completed forms and the data diskette downloaded from the bar code reader to the Data Manager on a daily basis. The electronic-data-downloading diskettes will be downloaded from the monitoring equipment and will be forwarded to the Data Manager by the Field Task Manager on a monthly basis (and more frequently if necessary).

\subsection{PROCEDURES FOR COLLECTING GROUNDWATER LEVEL DATA}

Field data collected during WAG 1 groundwater level monitoring will consist of manually measured water levels. Most of the data will be entered into the WAG 1 data base using bar code equipment. However, field documentation forms also will be completed by the sampling team. These forms will be compared with the data base at a later time to ensure that all the information previously entered into the bar code reader is correct. The following paragraphs describe procedures for completion of groundwater level monitoring (GW) forms.

\section{GW-03: WAG 1-Manual Water Level Measurements Form}

Before leaving the FOF, the Sample Task Leader will obtain from the GW-03 "Blank Form Book" the necessary number of forms to be used that day. New forms must be started each day. Upon arrival at the site, the Sample Task Leader will scan the project task code from a menu card, his badge number, the field logbook number, the form bar code label, and the equipment bar code identification (ID). The bar code reader will then enter a loop and ask for monitoring location to be scanned and depth to water to be manually entered. The "Comments" field is optional and will not be captured in the reader. If the Sample Task Leader wants any information concerning the event to be tracked in the data base, he or she will note that information in the "Comments" field of the form. The Data Manager will manually enter the information once the form has been submitted and the field data have been added to the data base. 


\subsection{PROCEDURES FOR COLLECTING GROUNDWATER QUALITY DATA}

The WAG 1 groundwater quality sampling team will be using a bar code reader in the field to record most of the information that will be tracked in the WAG 1 project data base. However, field documentation forms will be used by the project team to track and confirm necessary information.

\section{GWQ-01: WAG 1-Well Purging and Sampling Form}

Before leaving the FOF, the Sample Task Leader will obtain one form from the GWQ-01 "Blank Form Book" for each monitoring location to be visited that day. Upon arrival at the site, the Sample Task Leader will scan the monitoring location, the sample team's badges (by role), the field logbook number, the form bar code label, and the equipment bar code ID of the HORIBA (or equivalent) instrument installed at that location.

The bar code reader will then prompt the Sample Task Leader to enter the field measurements of temperature, $\mathrm{pH}$, conductivity, and dissolved oxygen. The Sample Task Leader will then manually enter the "Total depth of well" and "Depth to water from reference point." The bar code reader will calculate the height of the water column. The bar code reader will prompt the Sample Task Leader to enter the diameter of the well (i.e., 2 in., 4 in., or 6 in.). The bar code reader will then display the calculated fields citing "Height of water column," "Water column height," "total purge gal," and "casing volume." The Sample Task Leader will note all calculations displayed on the reader in the appropriate fields on the GWQ-01 form. The "Purge Sampling Method" will default to "pump." The reader will prompt the Sample Task Leader to enter "Final Purge Volume." The Sample Task Leader will then scan the bar code sample ID and the sample type and analytes from a menu card.

The "Comments" field is optional and will not be captured by the reader. If the Sample Task Leader wants any information concerning the event to be tracked in the data base, he or she will note that information in the "Comments" field of the form. The Data Manager will manually enter the information once the form has been submitted and the field data have been added to the data base.

\subsection{COMPLETING SAMPLE COLLECTION FORMS (WAS-01: WAG 1-Weekly Activity Schedule; FCTM-01: WAG 1-Field Collection Task Map; FAS-01: WAG 1-Field Activity Sheet)}

All sampling events will be scheduled by the Field Task Manager on a WAG $1-$ Weekly Activity Schedule (WAS-01). The Field Task Manager will provide the Data Manager with a copy of Form WAS-01 in order to have the WAG 1-Field Collection Task Map (FCTM-01) printed. The Sample Team Leader will use Form FCTM-01 to assemble the sample kits and record the sample numbers used.

Once the kits are assembled, the Sample Task Leader will initiate the sampling event by notifying the Data Manager to print the WAG 1-Field Activity Sheet (FAS-01). Form FAS-01 will be used in the field by the sampling team to record all sample collection. Any incorrect or additional information will be noted on the form by the Sample Task Leader. The form then will 
be returned to the Field Task Manager, who will review the form and forward it to the Data Manager for update of the data base.

\subsection{SAMPLE IDENTIFICATION AND LABELING}

Labeling of all samples shall be performed in accordance with ORNL WAG 6-FOP 9. The following information must be recorded on the sample label:

- site name,

- unique sample ID number,

- date and time of sample collection,

- matrix,

- name of sampler,

- sample preservation,

- types of analyses to be conducted, and

- cleaning lot number.

All labels must be waterproof and preprinted or completed in permanent ink. A bar code label also will be attached, then scanned for entry into the data base. An example sample label is included in Appendix D. Preprinted sample labels will be provided to the Sample Task Leader in advance of scheduled sampling.

\subsection{CHAIN OF CUSTODY}

Preprinted chain-of-custody forms will be provided after the scheduled sampling. Sample possession must be traceable and shall be maintained in accordance with ESP-500, "Manual Chain-of-Custody Procedures." To track sample possession, an official, documented chain-ofcustody form shall be maintained for each sample. A sample is in custody if one or more of the following criteria are met:

- it is in the possession of a sampling team member,

- it is in a sampling team member's view after being in possession, or

- it is in a designated secure area.

\section{COC-01: WAG 1-Chain-of-Custody Form}

When the samples are ready for shipment, the Sample Task Leader will note on Form FAS-01 which samples are to be shipped, and WAG 1-Chain-of-Custody Form (COC-01) (see Appendix D) will be printed by the Data Manager and signed by the Field Task Manager. Form COC-01 will accompany the samples to the analytical laboratory. A copy of the form will be retained in the project files.

The following information will be recorded on the completed Form COC-01:

- project name,

- signature of sampler, 
- sampling station,

- unique sample number,

- date and time of collection,

- grab or composite designation,

- matrix (i.e., groundwater),

- preservatives, and

- signatures of individual involved in sample transfer.

Chain-of-custody forms will be placed in a plastic cover and taped inside the shipping container used for sample transport from the field to the laboratory. When samples are relinquished to a shipping company for transport, the tracking number from the shipping bill/receipt will be recorded on the chain-of-custody form and in the field logbook. Individuals receiving samples will sign, date, and note the time of receipt on the chain-of-custody form. 


\section{REFERENCES}

DOE (U.S. Department of Energy) 1994. Site Characterization Plan for Groundwater in Waste Area Grouping 1 at Oak Ridge National Laboratory, Oak Ridge, Tennessee. DOE/OR/011194\&D2. Prepared by Martin Marietta Energy Systems, Inc, Oak Ridge National Laboratory, Oak Ridge, Tennessee, July.

Energy Systems (Martin Marietta Energy Systems, Inc.) 1992a. Site Characterization Summary Report for Waste Area Grouping 1. ORNL/ER-131/V4, Oak Ridge National Laboratory, Oak Ridge, Tennessee, June.

Energy Systems (Martin Marietta Energy Systems, Inc.) 1992b. WAG 1 Groundwater, Surface Water, and Sediment: Technical Memorandum 01-06. ORNL/ER/Sub-87/99053/57, Oak Ridge National Laboratory, Oak Ridge, Tennessee, June. 
APPENDIX A

WAG 1 READINESS REVIEW CHECKLIST 


\section{CDM Federal Programs Corporation READINESS REVIEW CHECKLIST}

\section{Initial Preparedness/Documentation}

A. Have all the appropriate doucments for the project been finalized and approved?

$\begin{array}{llll}S A P & \text { yes } & \text { no } & \text { Date approved } \\ D M P & \text { yes } & \text { no } & \text { Date approved } \\ \text { QAPP } & \text { yes } & \text { no } & \text { Date approved } \\ \text { HSP } & \text { yes_ no } & \text { Date approved } \\ \text { Others } & \text { yes_ } & \text { no_ } & \text { Date approved }\end{array}$

B. Have copies of the approved documents been submitted to subcontractors' Project Management, assigned field personnel, and Analytical Laboratory personnel?

$\begin{array}{lll}S A P & \text { yes } & \text { no } \\ D M P & \text { yes } & \text { no } \\ \text { QAPP } & \text { yes } & \text { no } \\ \text { HSP } & \text { yes } & \text { no } \\ \text { Others } & \text { yes } & \text { no }\end{array}$

C. Are applicable forms available and current with contract specifications? See Form List at the end of this checklist.

$$
\text { yes__ no }
$$

II. Personnel and Training

A. Have an appropriate number of personnel having the appropriate training been assigned to this project? (Attach a roster of personnel and brief description of qualifications.)

$$
\text { yes___ no }
$$

\begin{tabular}{|c|c|c|}
\hline CPR/First Aid Training & yes & no \\
\hline OSHA-40 hour & yes & no \\
\hline Field Procedures & yes & no \\
\hline$H \& S$ & yes & no \\
\hline Rad Worker II Training & yes & no \\
\hline ORNL Site Safety Orientation & yes & no \\
\hline ORNL General Employee Training (GET) & yes & no \\
\hline Defensive Driving on Non-Paved Surfaces & yes & no \\
\hline ORNL Contractor Security Briefing & yes & no \\
\hline
\end{tabular}

B. Is there documentation of training in the appropriate areas? 


\section{CDM Federal Programs Corporation READINESS REVIEW CHECKLIST}

C. Has the Health and Safety Officer been identified?

$$
\text { yes__ no }
$$

Name

D. Has the chain of command from field operations to management been defined and communicated to all personnel?

$$
\text { yes__ no }
$$

E. Are there backup personnel properly trained and available?

$$
\text { yes }
$$$$
\text { no }
$$

F. Have field personnel been trained in DOE Order 5000.3A?

$$
\text { yes__ no }
$$

\section{Mobilization Preparedness}

\section{Site Logistics}

A. Is the ORNL security organization aware of the project, the scope of activities to be accomplished, and the estimated duration of the project?

$$
\text { yes__ no }
$$

B. Have all drilling permits/clearances been granted or a schedule established for obtaining them?

$$
\text { yes__ no }
$$

C. Have the appropriate ORNL commands/facilities been informed of the activities and potential interfaces in their work areas?

$$
\text { yes__ no }
$$

D. Have arrangements been made for the disposal of drill cuttings, refuse, contaminated materials, and decontamination water?

$$
\text { yes__ no }
$$

E. Have arrangements been made for the location of field laboratories (e.g., telephone, electricity) and storage facilities?

$$
\text { yes }
$$

no 


\section{CDM Federal Programs Corporation READINESS REVIEW CHECKLIST}

\section{Laboratory Logistics}

A. Has a contract-approved laboratory been selected and made aware of the data quality objectives and the anticipated schedule of project activities? (Indicate name and address of primary laboratory.)

yes no

Name

Address

B. Has the selected laboratory been notified of when sampling will begin, the projected volume of samples, the types of samples, and when samples should start arriving for analysis?

yes__ no

C. Has a secondary, backup laboratory been selected and approved in case of emergency situations? (Indicate name and address of backup laboratory.)

yes no

Name

Address

D. Has notification been made to the selected sample transportation company? Have arrangements been made to ensure that appropriate chain-of-custody and quality control requirements can be achieved? (Indicate name and address of transportation company.)

yes__ no

E. Are an appropriate number of the correct type(s) of sample containers available for the anticipated work? (Attach a list of the types and numbers of containers available for this project.)

$$
\text { yes }
$$

no

\section{Materials and Equipment}

A. Have the necessary instruments/measurement equipment and associated calibration devices been assembled on-site to conduct the specified tests and analyses for this job? (Use the equipment list at the end of this checklist.)

$$
\text { yes }
$$

no 


\section{CDM Federal Programs Corporation READINESS REVIEW CHECKIIST}

B. Have all necessary materials and equipment been assembled to correctly collect, identify, preserve, and transport the types and number of samples to be taken for this job? (Use the equipment list at the end of this checklist.)

$$
\text { yes__ no }
$$

C. Have all the necessary types of personal protection and decontamination equipment been assembled and made ready for this job? (Use the equipment list at the end of this checklist.)

$$
\text { yes__ no }
$$

V. Quality Assurance

A. Is the CDM Federal Quality Assurance Program being implemented?

Comments:

yes

no

B. Have arrangements been made to have QA audits and surveillances?

Comments:

yes

no

C. Is there a system in place to identify, report, and evaluate any conditions adverse to quality?

Comments:

yes__ no 


\section{CDM Federal Programs Corporation EQUIPMENT CHECKLIST}

\section{Drilling/Sampling Equipment}
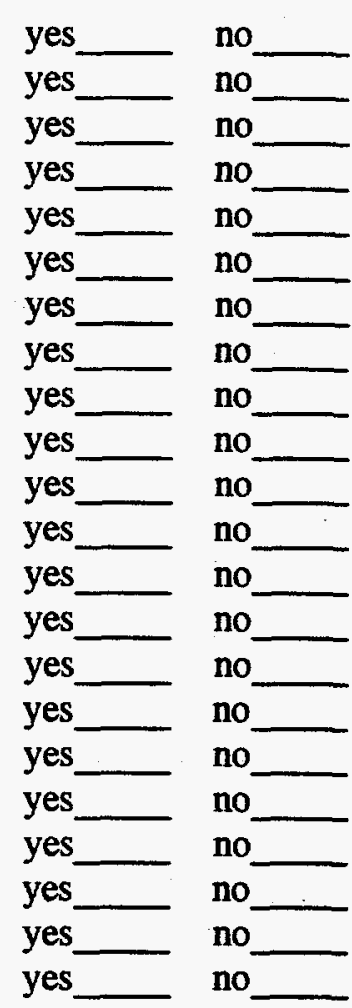

Barrier tape

Pocket tape measure (in tenths)

Munsell Soil Color Chart

USCS field soil classification guide

NIST traceable thermometer with armor case, specify range:

Garden sprayer, ss, 2 gal

Garden sprayer, ss, 4 gal

ASTM Type II water

Isopropanol (pesticide grade or better)

Liquinox or Alconox

Squirt bottles, Teflon or nalgene

$\mathrm{HCl}$ preservative

$\mathrm{HNO}_{3}$ preservative

$\mathrm{H}_{2} \mathrm{SO}_{4}$ preservative

$\mathrm{NaOH}$ preservative

Bucket, ss, 15 qt.

Coolers (ice chests)

Aluminum foil, heavy duty

Spatulas, ss

Stainless steel bowls, specify sizes:

Stainless steel pans, specify sizes:

Stainless steel spoons

\section{Health and Safety Equipment}

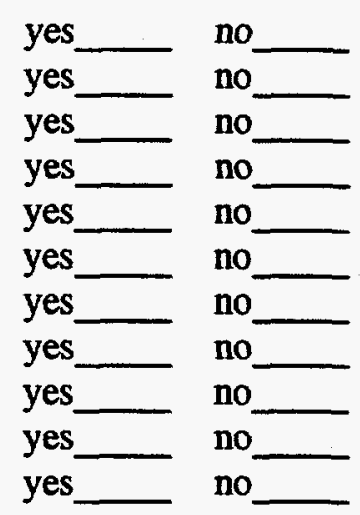

Beta/gamma meter

Alpha meter

OVA

OVA calibration gas (methane or hexane)

OVM

OVM calibration gas (isobutylene, $100 \mathrm{ppm}$ )

APR cartridges (MSA, Ultratwin), specify type

Disposable lens cleaning station

Eye wash station (specify type)

First-aid kit

\section{Personal Protective Equipment}

Coveralls, specify sizes:

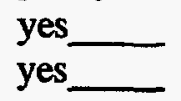

no

no

Cotton

Tyvek 


\section{CDM Federal Programs Corporation EQUIPMENT CHECKLIST}

Gloves, specify sizes:

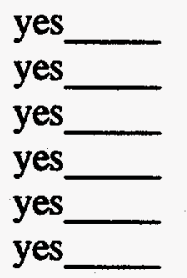

\begin{tabular}{ll}
\hline no & Cotton undergloves \\
no__ & Cotton work gloves \\
no & Latex, disposable \\
no__ & Leather work gloves \\
no__ & Nitrile \\
no__ & Other
\end{tabular}

yes no

Hard hats

Overboots, specify sizes:

yes

yes

no

no

Safety glasses (ANSI Z-87)

Shipping supplies

yes

yes

yes

yes no

no

no

no

no

FedEx labels, pouches, letters, boxes, etc.

Ziplock bags, specify size:

Blue Ice packs or ice

Sample shipping SOP

General supplies

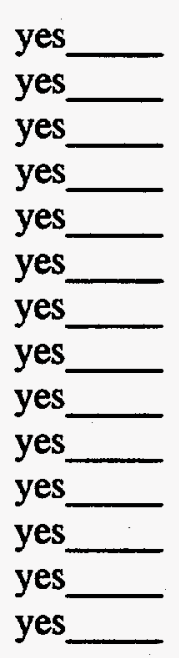

no

no

no

no

no

no

no

no

no

no

no

no

no

no

Tape
Clipboards, protective

Field logbooks (water resistant)

Fire extinguisher

Folding chairs

Folding table

Garbage bags

Kimwipes

Fiberglass measuring tape, specify length:

Office supplies (paper, scotch tape, pens, pencils, etc.)

Pin flags

Polyethylene sheeting

Sharpie markers (ultra-fine, fine, and bold)

Stakes, wooden

Surveying ribbon
yes
yes
no
Duct
yes
no
Acetate
no
Strapping 


\section{CDM Federal Programs Corporation EQUIPMENT CHECKLIST}

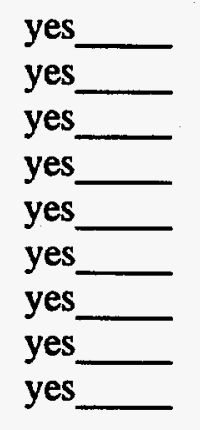

no

no

no

no

no

no

no.

no

no

Field Change Request

Nonconformance Report

Employee Meeting Record

Chain-of-custody

Maintenance and Calibration Form

Example Equipment Calibration Log

Boring Log

Container Log Sheet

CDM Federal Injury Report 


\section{APPENDIX B}

WAG 1 STANDARD OPERATING PROCEDURE FOR GEOPROBE INSTALLATION AND

GROUNDWATER SAMPLING 


\section{WAG 1 STANDARD OPERATING PROCEDURE FOR GEOPROBE INSTALLATION AND GROUNDWATER SAMPLING}

\section{OBJECTIVE}

The objective of this procedure is to provide direction for installing a groundwater sampling point using the Geoprobe ${ }^{\circledast}$ system to collect groundwater grab samples.

\section{BACKGROUND}

\subsection{DEFINITIONS}

Geoprobe System: A commercial groundwater sampling system in which a hydraulic device is used to advance a hollow-stem probe through soil for the purpose of collecting a groundwater sample.

Expandable drive point: A stainless steel well point (i.e., Geoprobe) attached to the leading rod of the Geoprobe unit that is left at the bottom of the boring when rods are removed.

\subsection{DISCUSSION}

The Geoprobe unit uses an expandable drive point to retrieve groundwater samples at its working depth. The Geoprobe unit remains completely sealed by a drive point or an expandable point at the end of the sample tube while it is pushed or driven to the desired sampling depth.

At the depth of interest, the Geoprobe unit rods will be pulled up approximately $2 \mathrm{ft}$, allowing the expandable drive point to remain at the bottom of the boring and thereby creating $2 \mathrm{ft}$ of open borehole for the collection of groundwater grab samples.

\section{RESPONSIBILITIES}

Site Manager: The Site Manager is responsible for ensuring that the Geoprobe sampling points are completed in accordance with the project requirements.

- Geoprobe is a registered trademark of Geoprobe Systems, Inc., Selina, Kansas. 
Field Task Manager: The Field Task Manager is responsible for ensuring that the field team installs the Geoprobe sampling points in accordance with the project requirements.

\section{REQUIRED EQUIPMENT}

The following tools are required to install and to sample using the Geoprobe system.

- Extension rods

- Extension rod couplers

- Expandable drive points

- Hand sampling pump

- Polyethylene tubing
- Extension rod handle

- Threaded drive point

- Peristaltic pump

- Mini-bailer

- Cubitainer ${ }^{\mathrm{rm}}$

\section{PROCEDURES}

\subsection{ASSEMBLY}

After decontaminating parts thoroughly, assemble the Geoprobe sampling system. All parts must fit tightly. Damage could occur during probing if threaded assemblage is not tight.

\subsection{GEOPROBE INSTALLATION}

Attach assembled expandable drive point on Geoprobe rod. Place the drive cap on top of the probe rod. A 12-in. probe rod is recommended to start the well point. Replace the 12-in. rod with a 36-in. rod as soon as the sampler is driven below the surface.

Drive the well point with the attached probe rods to the top of the desired interval, which will be bedrock/refusal or first encountered groundwater, using the hydraulically-powered Geoprobe unit.

After bedrock/refusal has been located, pull the probe rods approximately $2 \mathrm{ft}$ up to create a small gap for water to enter the leading rod.

IMPORTANT: Some soil conditions may warrant using a retractable or solid drive point to preprobe the hole to the desired sampling depth. Do not drive the sampler into bedrock or any other impenetrable layer. 


\subsection{SAMPLING}

A mini-bailer, a Waterra ${ }^{\text {Tt }}$ pump, or a peristaltic pump will be used to collect a groundwater grab sample. The groundwater sample will be transferred into a 4-L Cubitainer ${ }^{\text {Th }}$ for laboratory analysis. To collect sufficient sample volume for groundwater analysis, this procedure may need to be repeated over a 24 -hour period.

\subsection{DECONTAMINATION}

Disassemble and remove all parts. Decontaminate equipment according to ESP-802.

\section{REFERENCE}

Geoprobe Systems, Inc., September 1991. "The Geoprobe Groundwater Sampling System." Selina, Kansas, September. 
APPENDIX C

WAG 1 WELL DEVELOPMENT DATA 

HYG103 DATA NUMi

\begin{tabular}{|c|c|c|c|c|c|c|c|c|}
\hline IELL & $\begin{array}{l}\text { STA } \\
\text { DATE }\end{array}$ & $\begin{array}{l}\text { STARI } \\
\text { TIME }\end{array}$ & $\begin{array}{l}\text { END } \\
\text { TIME }\end{array}$ & $\begin{array}{c}\text { LAST } \\
\text { VOLUME }\end{array}$ & $\begin{array}{l}\text { LASI } \\
\text { COND }\end{array}$ & $\begin{array}{r}\text { LAST } \\
\text { PH }\end{array}$ & $\begin{array}{l}\text { IURB ID } \\
\text { ITr }\end{array}$ & TEMP \\
\hline $\begin{array}{l}\mathbf{5 3 3} \\
\mathbf{5 3 6} \\
\mathbf{5 3 6} \\
\mathbf{5 3 8} \\
\mathbf{5 3 8} \\
\mathbf{5 3 9} \\
\mathbf{5 4 0} \\
\mathbf{5 4 1} \\
\mathbf{5 4 1} \\
\mathbf{5 4 3} \\
\mathbf{5 4 3} \\
\mathbf{5 4 5} \\
\mathbf{5 4 6} \\
\mathbf{5 4 6} \\
\mathbf{5 4 7} \\
\mathbf{5 4 7} \\
\mathbf{5 4 8} \\
\mathbf{5 4 8} \\
\mathbf{5 4 9} \\
\mathbf{5 4 9} \\
\mathbf{5 5 0} \\
\mathbf{5 5 3} \\
\mathbf{5 5 3} \\
\mathbf{5 5 4} \\
\mathbf{5 5 4} \\
\mathbf{5 5 4} \\
\mathbf{5 5 8} \\
\mathbf{5 6 1} \\
\mathbf{5 6 3} \\
\mathbf{5 6 3} \\
\mathbf{5 6 4} \\
\mathbf{5 6 4} \\
\mathbf{5 6 6} \\
\mathbf{5 6 6} \\
\mathbf{5 7 1} \\
\mathbf{5 7 1} \\
\mathbf{5 7 2} \\
\mathbf{5 7 2} \\
\mathbf{5 7 9} \\
\mathbf{5 8 3} \\
\mathbf{5 8 7} \\
\mathbf{5 8 9} \\
\mathbf{5 9 9} \\
\mathbf{5 9 7} \\
\mathbf{5 9 8} \\
\mathbf{5 9 8} \\
\mathbf{5 9 9}\end{array}$ & 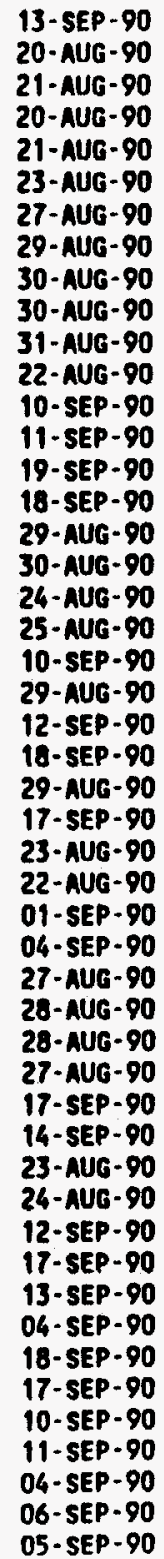 & $\begin{array}{r}1050 \\
850 \\
812 \\
1110 \\
817 \\
1008 \\
905 \\
915 \\
805 \\
1040 \\
815 \\
920 \\
1031 \\
817 \\
858 \\
1437 \\
920 \\
758 \\
1015 \\
800 \\
928 \\
1253 \\
807 \\
748 \\
1350 \\
947 \\
945 \\
820 \\
800 \\
1100 \\
1020 \\
950 \\
1450 \\
745 \\
950 \\
1530 \\
1106 \\
945 \\
1240 \\
901 \\
935 \\
805 \\
1320 \\
930 \\
820 \\
1432 \\
900 \\
1030 \\
\end{array}$ & $\begin{array}{r}1645 \\
1609 \\
855 \\
1535 \\
1240 \\
1527 \\
1500 \\
1555 \\
945 \\
1505 \\
815 \\
1413 \\
1515 \\
1403 \\
957 \\
1514 \\
1435 \\
758 \\
1450 \\
1530 \\
1336 \\
1253 \\
855 \\
818 \\
1410 \\
1440 \\
1330 \\
1520 \\
800 \\
1420 \\
1356 \\
1530 \\
1600 \\
1050 \\
1445 \\
1613 \\
1510 \\
1350 \\
1415 \\
1541 \\
1319 \\
1400 \\
1320 \\
1600 \\
1505 \\
1449 \\
1454 \\
1550\end{array}$ & $\begin{array}{r}16.00 \\
39.00 \\
47.00 \\
5.00 \\
37.00 \\
10.50 \\
30.00 \\
53.00 \\
35.00 \\
50.00 \\
45.00 \\
2.00 \\
8.00 \\
1.00 \\
6.00 \\
8.00 \\
23.00 \\
70.00 \\
1.50 \\
12.00 \\
1.00 \\
8.00 \\
\\
\\
6.00 \\
2.50 \\
6.00 \\
40.00 \\
50.00 \\
.50 \\
46.00 \\
25.00 \\
17.00 \\
5.50 \\
.60 \\
20.00 \\
18.00 \\
1.00 \\
12.00 \\
20.00 \\
12.00\end{array}$ & $\begin{array}{r}697.00 \\
725.70 \\
446.00 \\
508.00 \\
477.00 \\
699.00 \\
905.40 \\
897.60 \\
1222.00 \\
1198.00 \\
630.00 \\
591.00 \\
568.00 \\
500.00 \\
440.00 \\
928.00 \\
530.90 \\
524.20 \\
711.00 \\
451.00 \\
618.00 \\
493.00 \\
410.00 \\
592.00 \\
520.60 \\
427.50 \\
\end{array}$ & $\begin{array}{l}7.21 \\
6.90 \\
7.23 \\
7.01 \\
7.64 \\
7.34 \\
7.20 \\
7.20 \\
6.74 \\
6.46 \\
7.85 \\
7.37 \\
7.41 \\
7.34 \\
7.30 \\
7.17 \\
7.00 \\
7.20 \\
7.16 \\
6.63 \\
6.79 \\
7.16 \\
7.37 \\
7.32 \\
7.90 \\
7.80 \\
7.40 \\
7.90 \\
7.60 \\
7.50 \\
7.03 \\
7.02 \\
7.20 \\
7.16 \\
7.00 \\
10.30 \\
7.22 \\
7.00 \\
7.74 \\
7.31 \\
7.90 \\
7.90 \\
6.92 \\
7.66 \\
7.40\end{array}$ & 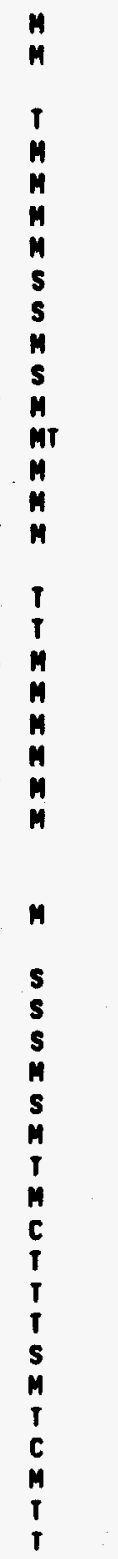 & $\begin{array}{r}19 \\
29.8 \\
19.2 \\
22.4 \\
26.8 \\
26.1 \\
28.6 \\
21.1 \\
35.4 \\
21.9 \\
21.8 \\
24.3 \\
20.2 \\
18.5 \\
18.6 \\
27.8 \\
21 \\
23.4 \\
30.5 \\
24.1 \\
22.1 \\
20.3 \\
26.8 \\
24.8 \\
29.4 \\
35.8 \\
26.9 \\
23.1 \\
29.1 \\
26.1 \\
17.3 \\
21.3 \\
32.1 \\
27 \\
27.5 \\
16.7 \\
22.6 \\
23.3 \\
23.4 \\
27.3 \\
31.5 \\
22.5 \\
23.4\end{array}$ \\
\hline
\end{tabular}


HYG103 DATA DUMF

\begin{tabular}{|c|c|c|c|c|c|c|c|c|}
\hline MELL & $\begin{array}{l}\text { START } \\
\text { DATE }\end{array}$ & $\begin{array}{c}\text { SIART } \\
\text { IIME }\end{array}$ & $\begin{array}{l}\text { END } \\
\text { TIME }\end{array}$ & $\begin{array}{r}\text { LAST } \\
\text { VOLUME }\end{array}$ & $\begin{array}{l}\text { LAST } \\
\text { COND }\end{array}$ & $\begin{array}{r}\text { LAST } \\
\text { PH } \\
0 . .\end{array}$ & $\begin{array}{l}\text { TURBID } \\
\text { IIY }\end{array}$ & TEMP \\
\hline $\begin{array}{l}601 \\
602 \\
602 \\
604 \\
604 \\
610 \\
610 \\
611 \\
611 \\
611 \\
612 \\
614 \\
615 \\
615 \\
616 \\
618 \\
618 \\
620 \\
620 \\
621 \\
622 \\
622 \\
623 \\
623 \\
626 \\
634 \\
634 \\
643 \\
1250 \\
1250 \\
1250 \\
1250 \\
1250 \\
1251 \\
1251 \\
1251 \\
1251 \\
1251 \\
1251 \\
1251 \\
1252 \\
1252 \\
1252 \\
1252 \\
1253\end{array}$ & 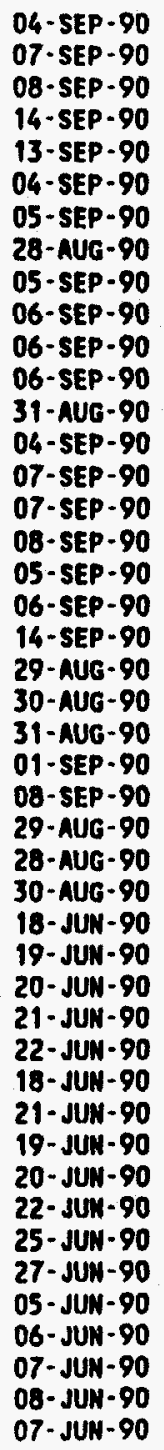 & $\begin{array}{r}935 \\
900 \\
756 \\
815 \\
940 \\
1020 \\
758 \\
1405 \\
1010 \\
748 \\
1030 \\
1036 \\
1020 \\
910 \\
915 \\
1200 \\
803 \\
1108 \\
750 \\
1238 \\
938 \\
1315 \\
940 \\
730 \\
830 \\
838 \\
1019 \\
825 \\
1045 \\
1250 \\
845 \\
800 \\
820 \\
1345 \\
940 \\
815 \\
955 \\
1030 \\
1000 \\
1000 \\
1300 \\
905 \\
850 \\
830 \\
1045\end{array}$ & $\begin{array}{r}1615 \\
1446 \\
1024 \\
1015 \\
1510 \\
1559 \\
805 \\
1545 \\
1555 \\
748 \\
1319 \\
1310 \\
1505 \\
910 \\
1400 \\
1600 \\
1124 \\
1615 \\
851 \\
1459 \\
1215 \\
1605 \\
1450 \\
730 \\
935 \\
1455 \\
1530 \\
855 \\
1235 \\
1250 \\
1430 \\
800 \\
820 \\
1440 \\
1400 \\
1445 \\
1330 \\
1500 \\
1500 \\
1500 \\
1415 \\
1445 \\
920 \\
850 \\
1355\end{array}$ & $\begin{array}{r}5.00 \\
\\
9.00 \\
6.50 \\
6.00 \\
6.50 \\
.66 \\
1.20 \\
.75 \\
.60 \\
.75 \\
2.00 \\
2.50 \\
1.20 \\
4.00 \\
5.00 \\
53.00 \\
61.00 \\
35.00 \\
1.00 \\
13.00 \\
7.00 \\
9.00 \\
.60 \\
\\
3.00 \\
18.00 \\
23.00 \\
33.00 \\
38.00 \\
44.00 \\
18.00 \\
275.00 \\
95.00 \\
195.00 \\
360.00 \\
495.00 \\
630.00 \\
5.00 \\
19.00 \\
24.00 \\
28.00 \\
82.00\end{array}$ & $\begin{array}{r}802.60 \\
698.00 \\
722.00 \\
464.60 \\
472.30 \\
601.00 \\
754.00 \\
\\
761.00 \\
478.20 \\
652.00 \\
738.00 \\
782.00 \\
851.00 \\
563.50 \\
605.30 \\
667.00 \\
326.00 \\
837.10 \\
788.20 \\
582.10 \\
671.00 \\
731.00 \\
1118.40 \\
600.00 \\
620.00 \\
520.00 \\
520.00 \\
685.00 \\
225.00 \\
190.00 \\
200.00 \\
205.00 \\
275.00 \\
248.00 \\
255.00 \\
600.00 \\
520.00 \\
480.00 \\
500.00 \\
405.00\end{array}$ & $\begin{array}{c}7.20 \\
7.49 \\
7.24 \\
7.60 \\
7.60 \\
6.99 \\
6.95 \\
6.93 \\
10.93 \\
7.60 \\
7.37 \\
7.13 \\
6.98 \\
6.73 \\
6.90 \\
6.90 \\
8.12 \\
9.35 \\
7.60 \\
7.60 \\
8.30 \\
7.24 \\
7.27 \\
6.46 \\
8.27 \\
7.86 \\
7.51 \\
7.81 \\
7.82 \\
8.12 \\
7.24 \\
7.49 \\
7.15 \\
7.55 \\
7.45 \\
7.54 \\
8.18 \\
7.94 \\
7.84 \\
7.84 \\
8.14\end{array}$ & $\begin{array}{l}M \\
M \\
T \\
M \\
M \\
M \\
I \\
S \\
S \\
S \\
M \\
S \\
I \\
T \\
1 \\
T \\
T \\
M \\
S \\
S \\
C \\
5 \\
S \\
S \\
M \\
S \\
M \\
S \\
S \\
C \\
S \\
S \\
S \\
C \\
C\end{array}$ & $\begin{array}{r}25.6 \\
22 \\
21.6 \\
24.6 \\
25.5 \\
24.5 \\
22.1 \\
19.3 \\
\\
28.7 \\
28 \\
24.6 \\
\\
30.2 \\
23.9 \\
21.9 \\
17.3 \\
19.3 \\
23 \\
27.2 \\
31.7 \\
23.6 \\
19.7 \\
20.1 \\
22.9 \\
23.5 \\
22.1 \\
19 \\
16.1 \\
16 \\
22.3 \\
18.7 \\
16.8 \\
20.2 \\
17.2 \\
15.8 \\
17.2 \\
19.2 \\
21.2 \\
16.5 \\
16.2 \\
16.2\end{array}$ \\
\hline
\end{tabular}

94 rows selected. 


\section{APPENDIX D}

WAG 1 FIELD DOCUMENTATION FORMS 

WAG 1 - MANUAL WATER LEVEL MEASUREMENTS FORM (GW-03)

STL Badge No.:

Weather:

\begin{tabular}{|c|c|c|c|c|c|c|c|}
\hline $\begin{array}{l}\text { Monitoring } \\
\text { Location }\end{array}$ & Time & $\begin{array}{l}\text { Depth to } \\
\text { Water }\end{array}$ & Comments & $\begin{array}{l}\text { Monitoring } \\
\text { Location }\end{array}$ & Time & $\begin{array}{l}\text { Depth to } \\
\text { Water }\end{array}$ & Comments \\
\hline & & & & & & & \\
\hline & & & & & & & \\
\hline & & & & & & & \\
\hline & & & & & & & \\
\hline & & & & & & & \\
\hline & & & & & & & . \\
\hline & & & & & & & \\
\hline & & & & & & & \\
\hline & & & & & & & \\
\hline & & & & & & & \\
\hline & & & & & & & \\
\hline & & & & & & & \\
\hline & & & & & & & \\
\hline & & & & & & & \\
\hline & & & & & & & \\
\hline & & & & & & & \\
\hline & & & & & & & \\
\hline & & & & & & & \\
\hline & & & & & & & \\
\hline & & & & & & & \\
\hline & & & & & & & \\
\hline & & & & & & & \\
\hline & & & & & & & \\
\hline & & & & & & & \\
\hline
\end{tabular}

Field Logbook Number:

Equipment Bar Code ID:

Date:

Form Bar Code Label

Sample Task Leader Signature/Date:

Data Entry Signature/Date:

Data Verification Signature/Date: 
Monitoring Location:

STL Badge No.:

Weather:

Comments:
Field Logbook Number:

Date:

\section{Total depth of well}

Depth to water from reference point

Height of water column

Water column height

$2^{n}-0.16$

(×) $4^{\prime \prime}-0.65 \mathrm{gal} / \mathrm{ft}(=)$ total purge gal

$6^{n}-1.47$

gal/casing volume $(X) 3$ casing volumes $(=)$

Purge Method

Sampling Method

Purge water containerized?

PURGE RATE (During Well Purging)

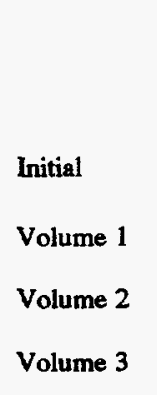

\begin{tabular}{|l|l|}
\hline Time & \multirow{2}{*}{. } \\
\hline & \\
\hline & \\
\hline & \\
\hline & \\
\hline
\end{tabular}

Time Sampled

HORIBA (Serial No.):

Temperature $\left({ }^{\circ} \mathrm{C}\right)$ :

\section{$\mathbf{Y} / \mathbf{N}$}

Procedure:

Procedure:

gpm

\section{Temperatare}

e)

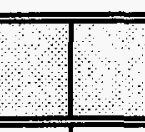

\section{pH}

(su)

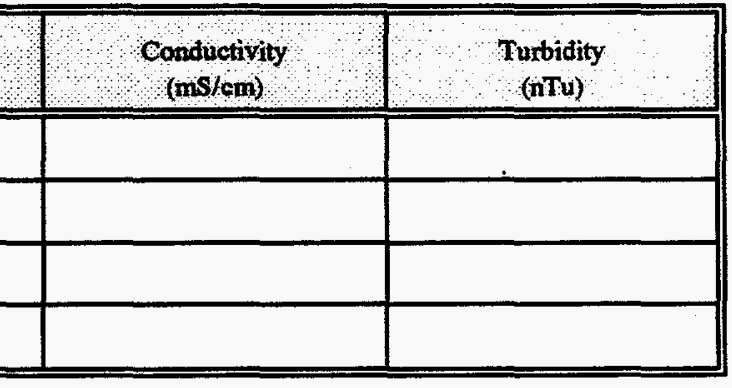

(during sampling)

Recalibration:

DO (mg/L):

Form Bar Code Label

Sample Task Leader Signature/Date:

Data Entry Signature/Date:

Data Verification Signature/Date: 
WAG 1 - RECORD OF REPAIR FORM (RF-01)

DATE:

EMPLOYEE BADGE NO.:

EQUIPMENT BAR CODE NO.:

EQUIPMENT STATUS: IN-USE (circle one)

AVAILABLE

TEMPORARILY

RETIRED

OUT-OF-SERVICE

Disposition of unit:

Comments:

Was damage discovered during routine site inspection? Yes No

If yes, list inspection form number or logbook number.

Nature of damage if known: Date found:

Was unit repairable in situ? Yes No

If yes, list repairs made and person making them.

Did in situ repairs include replacing any parts/accessories? Yes No

If yes, list and describe.

Was equipment sent to offsite vendor for repair? Yes No

If yes, list:

Vendor: Address:

Airbill No. (if shipped):

Work Order No:

Date Sent:

Initial:

Date returned: Received by:

Type of repair:

Was unit retumed in good working condition? Yes / No

If no, please describe:

Returned Equipment Status:

Form Bar Code Label

Sample Task Leader Signature/Date:

Data Entry Signature/Date:

Data Verification Signature/Date:

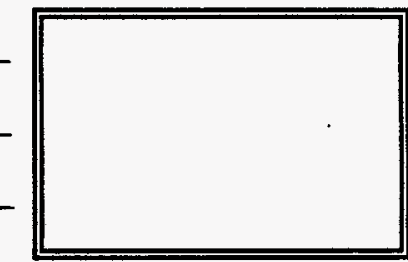




\section{WAG 1 - MONITORING VARIANCE REQUEST FORM (MV-01)}

(Once completed, insert this form into site notebook. If more than one site is affected, insert a copy of this form into all appropriate notebooks.)

Matrix:

ID of affected site(s):

Name and title of person making request:

Date:

Document very specifically the variance being requested. Be sure to identify all pertinent Data Quality Objectives that are affected by this variance:

Document the reasons for requesting the variance:

Document the time scale of the variance. Include dates at which this variance will start and end (if applicable):

Variance approval signature: STL:

Date:

FTM:

Date:

WAG 6 Project Manager:

Date:

Data entry signature/date:

Data verification signature/date: 
WAG 1 - WEEKLY ACTIVITY SCHEDULE (WAS-01)

FTM Badge No.:

Date $(\mathrm{mm} / \mathrm{dd} / \mathrm{yy})$ :

\begin{tabular}{|c|c|c|c|}
\hline \multicolumn{4}{|c|}{ Groundwater Quality } \\
\hline \multicolumn{4}{|l|}{ Activity Period: } \\
\hline \multirow{2}{*}{ Site IDs } & \multicolumn{3}{|c|}{ Surplus Bottles } \\
\hline & Quantity & Type & Volume \\
\hline & & & \\
\hline & & & \\
\hline & & & \\
\hline & & & \\
\hline & & & \\
\hline & & & \\
\hline & & & \\
\hline & & & \\
\hline & & & \\
\hline & & & \\
\hline & & & \\
\hline & & & \\
\hline & & & \\
\hline & & & \\
\hline & & & \\
\hline & & & \\
\hline & & & \\
\hline & & & \\
\hline & & & \\
\hline & & & \\
\hline & & & \\
\hline
\end{tabular}

FTM Signature/Date:

Data Entry Signature/Date:

Data Verification Signature/Date: 
WAG 1 - FIELD COLLECTION TASK MAP (FCTM-01)

Field Matrix:

Task:

Sampling Date:
Kit Identifier:

Kit Preparation Date:

Field Activity Sheet Number:

Field Logbook Number:

\begin{tabular}{|c|c|c|c|c|c|c|c|c|c|c|}
\hline \multirow{2}{*}{$\begin{array}{l}\text { Monitoring } \\
\text { Location }\end{array}$} & \multirow{2}{*}{$\begin{array}{l}\text { Sample } \\
\text { ID }\end{array}$} & \multirow{2}{*}{$\begin{array}{c}\text { Collection } \\
\text { Device }\end{array}$} & \multirow{2}{*}{$\begin{array}{l}\text { Collection } \\
\text { FOP }\end{array}$} & \multicolumn{3}{|c|}{ Sample Container } & \multirow[b]{2}{*}{ Process } & \multirow[b]{2}{*}{ Preservative } & \multirow{2}{*}{$\begin{array}{l}\text { Analysis } \\
\text { Group }\end{array}$} & \multirow{2}{*}{$\begin{array}{c}\text { Sample } \\
\text { Type }\end{array}$} \\
\hline & & & & Size & Type & $\begin{array}{l}\text { Clean } \\
\text { Lot }\end{array}$ & & & & \\
\hline & & & & & & & & & & \\
\hline & & & & & & & & & & \\
\hline & & & & & & & & & & \\
\hline & & & & & & & & & & \\
\hline & & & & & & & & & & \\
\hline & & & & & & & & & & \\
\hline & & & & & & & & & & \\
\hline & & & & & & & & & & \\
\hline & & & & & & & & & & \\
\hline
\end{tabular}

Completed By:

Date: 
WAG 1 - FIELD ACTIVITY SHEET (FAS-01)

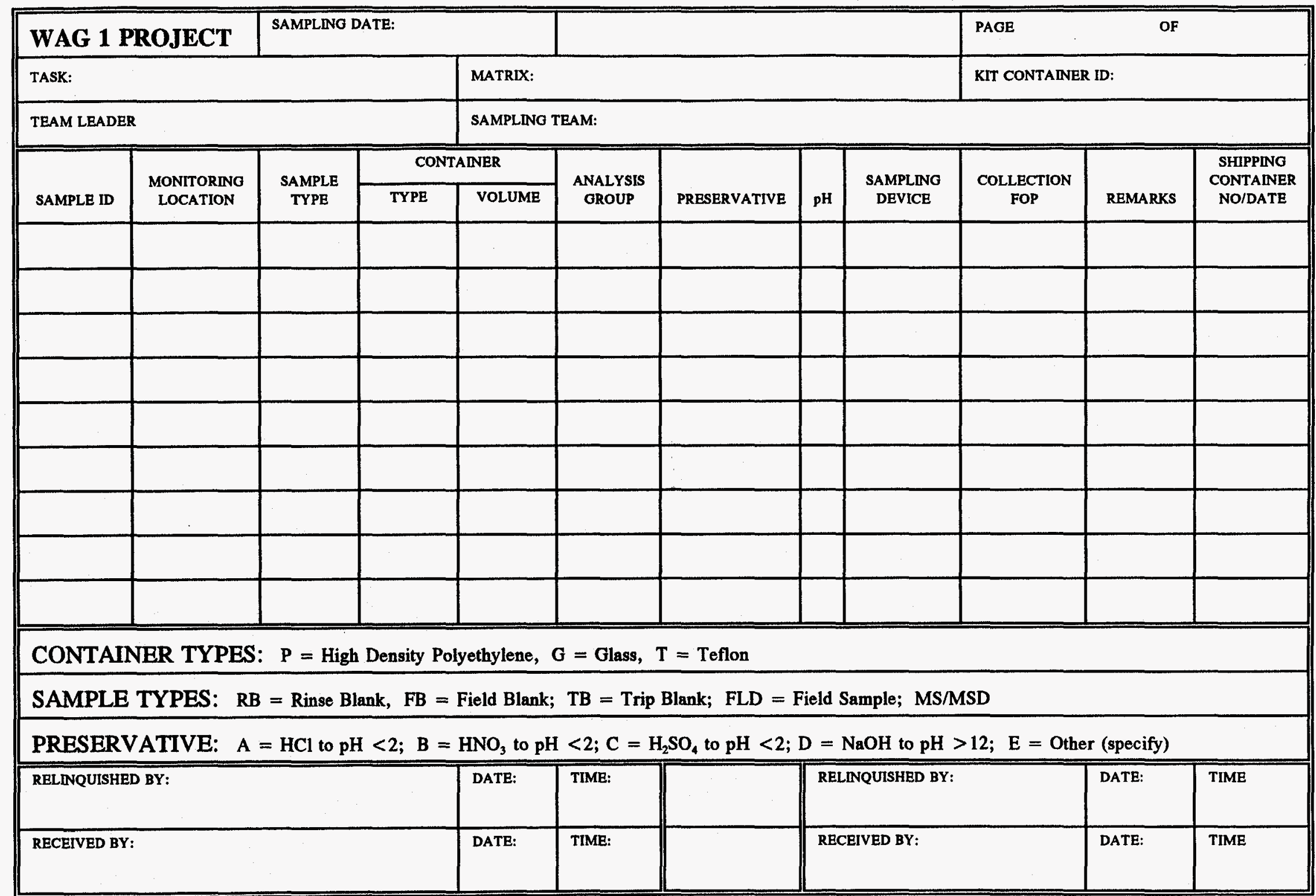


WAG 1 - CHAIN OF CUSTODY (COC-01)

\begin{tabular}{|c|c|c|c|c|c|c|c|c|c|c|}
\hline \multirow{2}{*}{$\begin{array}{l}\text { Sample } \\
\text { ID }\end{array}$} & \multirow{2}{*}{$\begin{array}{l}\text { Sample } \\
\text { Location }\end{array}$} & \multirow{2}{*}{$\begin{array}{l}\text { Sample } \\
\text { Date }\end{array}$} & \multirow{2}{*}{$\begin{array}{l}\text { Sample } \\
\text { Time }\end{array}$} & \multirow{2}{*}{$\begin{array}{l}\text { Sample } \\
\text { Type }\end{array}$} & \multicolumn{2}{|c|}{ Container } & \multirow[t]{2}{*}{ Preservative } & \multirow{2}{*}{$\begin{array}{l}\text { Requested } \\
\text { Analysis }\end{array}$} & \multirow{2}{*}{$\begin{array}{l}\text { Transferred } \\
\text { from } \\
\text { FAS No. }\end{array}$} & \multirow[t]{2}{*}{ Remarks } \\
\hline & & & & & Type & Volume & & & & \\
\hline & & & & & & & & & & \\
\hline & & & & & & & & & & \\
\hline & & & & & & & & & & \\
\hline & & & & & & & & & & \\
\hline & & & & & & & & & & \\
\hline & & & & & & & & & & \\
\hline & & & & & & & & & & \\
\hline & & & & & & & & & & \\
\hline \multicolumn{11}{|c|}{ Sample Types: RB $=$ Rinse Blank, FB $=$ Field Blank, TB $=$ Trip Blank, FLD $=$ Field Sample, MS $/$ MSD } \\
\hline \multicolumn{11}{|c|}{ Container Types: $\mathbf{P}=$ High Density Polyethylene, $\mathbf{G}=$ Glass, $T=$ Teflon } \\
\hline \multicolumn{11}{|c|}{ Preservative: } \\
\hline \multicolumn{3}{|c|}{ Laboratory: } & \multicolumn{3}{|c|}{ Date Submitted to Lab: } & \multicolumn{2}{|l|}{ SDG ID: } & \multicolumn{2}{|c|}{ Cooler Temperature: } & ${ }^{\circ} \mathrm{C}$ \\
\hline \multicolumn{3}{|c|}{ Relinquished By: } & Date: & Time: & & \multicolumn{3}{|c|}{ Received By: } & Date: & Time: \\
\hline \multicolumn{3}{|c|}{ Relinquished by: } & Date: & Time: & & \multicolumn{3}{|c|}{ Received By: } & Date: & Time: \\
\hline \multicolumn{3}{|c|}{ Relinquished by: } & Date: & Time: & & \multicolumn{3}{|c|}{ Received By: } & Date: & Time: \\
\hline \multicolumn{3}{|c|}{ Sample Disposed by: } & & Date: & & Time: & & Airbill No.: & & \\
\hline
\end{tabular}


D-11

\begin{tabular}{|c|c|c|}
\hline & \multicolumn{2}{|c|}{$\begin{array}{l}\text { CDM FEDERAL PROGRAMS CORPORATION } \\
\text { a maidinry of Camp Dreacer \& MeKee Inc. }\end{array}$} \\
\hline $\begin{array}{l}\text { Sample Bar Code ID: } \\
\text { Sample Date: } \\
\text { Sample Time: } \\
\text { Monitoring Location: } \\
\text { Sample Type: }\end{array}$ & $\begin{array}{l}\text { D Grab } \\
\text { D Composite } \\
\text { D Oher }\end{array}$ & $\begin{array}{l}\text { Project Number: } \\
\text { Analysis: } \\
\text { Collected By: } \\
\text { Q Sedimone } \\
\text { O Water } \\
\text { D Other }\end{array}$ \\
\hline Presarvative: & $\begin{array}{l}0 \mathrm{HCl} \\
0 \mathrm{HNO}, \\
0 \mathrm{HzO}_{2}\end{array}$ & $\begin{array}{l}0 \text { lee } \\
0 \text { NaOH } \\
0 \text { Oher }\end{array}$ \\
\hline $\begin{array}{l}\text { Holding Time: } \\
\text { Cleaning Lot : }\end{array}$ & - s & FAS: \\
\hline
\end{tabular}

Sample Label 
APPENDIX E

FIELD PROCEDURES 

Method Number: ESP 302-1

Revision Number: 0

Date: August 29, 1988

Page: 1 of 7

\author{
MARTIN MARIETTA ENERGY SYSTEYS, INC \\ ENVIRONIENTAL SURVEIIIANCE PROCEDURES
}

SUBJECT: GROUNDWATER SAMPIIHG PROCEDURES: WATER LEVEL MEASUREMENTS USING WA':ER IEVEL INDICATOR

I. Scope/Applications

This procedure outlines methods of obtaining water level measurements in completed wells. The use of conducting probe and a weighted steel or fiberglass tape are described.

II. Reference

A. A Compendium of Superfund Field operations Methods, EPA/540/P-87/001, U.S. Environmental Protection Agency, Washington, D.C., 1987.

B. Engineering support Branch standard Operating Procedures and Quality Assurance Manua?, U.S. Environmental Protection Agency, Region IV Environmental Service Division, Georgia, April 1, 1986.

C. The Environmental survey Manual - DOE/EH-0053, U.S. Department of Energy, August 1987.

D. RCRA Groundwater Monitoring Technical Enforcement Guidance Document, OSWER-9950.1, Sept. 1986.

III. Summary of Method

The electronic water level indicator (such as an M-Scope) is an instrument with conducting probes. The probe is lowered by means of an electrical cord from the top of the well casing to the water level. When the probe intersects the water a circuit is completed activating either a light, alarm or meter. The depth to water level is determined by reading the measured and marked increments on the lowering cord. 
Method Number: ESP 302-1

Revision Number: 0

Date: August 29, 1988

Page: 2 of 7

YLARTIN YARIETTA ENERGY SYSTEMS, INC

ENVIRONMENTAL SURVEILIANCE PROCEDURES

The steel or fiberglass tape is marked in measured increments. It is lowered through the well, and hits the water surface making a noise. The distance from the top of the well casing is then read to determine water level.

IV. comments

Groundwater with dilute ionic content may not conduct enough current between the electrodes of the $\$$-scope to activate the instrument.

Measuring tapes with a "plopper" usually have a limit of about $100 \mathrm{ft}$. The weight will be stainless steel or an inert material approved in the sampling and analysis plan.

All measuring devices will be calibrated with an approved standard.

Note: This procedure is complete when the manufacturers' calibration and maintenance instructions are attached for the instruments to be used.

v. Reouired Equipment and Apparatus

A. Electronic water level indicator: These instruments are conducting probes used to collect water level data.

B. Tape Neasure with "plopper"

vI. Safe iy

It is Energy systems policy to maintain an effective program for control of employee exposure to chemical, radiological, and physical stress which is consistent with the requirements of Martin Marietta Corporation, DOE, and OSHA established standards and requirements. All Field personnel will be provided with appropriate protective clothing and safety equipment. 
Method Number: ESP 302-1

Revision Number: 0

Date: August 29, 1988

Page: 3 of 7

MARTIN MARIETTA ENERGY SYSTEYS, INC

ENVIRONRENTAL SURVEILIANCE PROCEDURES

As - minimum, field personnel are required to wear steel capped safety shoes and safety glasses while performing this urocedure. Refer to a site specific health and safety plan for detailed health and safety procedures. This plan should be reviewed prior to beginning work.

VII. Procedures

A. Unlock and open well; note condition of well and don clean gloves.

B. Record sampling station number, date, time, weather conditions, and any other well-specific pertinent information.

c. Locate reference mark at top of well casing.

1. If reference mark is not present, make one on highest side of casing.

2. Make a scratch on the outside edge of the well casing with a file or suitable instrument, being careful that cuttings do not fall in well casing.

3. If reference mark is not present, alert management.

D. Collect water level measurements with electronic water level indicator.

1. Check bittery on cleared electronic water level indicator and on alarm.

2. Lower electronic water level indicator probe into well making sure the cord or the probe does not scrape the sides of the well casing.

3. When the alarm sounds and/or the red light illuminates, stop lowering the probe.

4. Pull up on the probe until alarm no longer sounds. 
Method Number: ESP 302-1

Revision Number: 0

Date: August 29, 1988

Page: 4 of 7

MARTIN YARIETTA ENERGY SYSTEMS, INC

ENVIRONRIENTAL SURVEILIANCE PROCEDURES

5. Lower probe again slowly. stop at the instant the alarm sounds and/or the light comes on and stays on.

6. Hold cord to side of casing where reference mark is etched.

7. Mark cord with thumb were it touches reference mark.

8. Use measuring device to determine distance from last marked increment to marked point on cord. The total depth is the distance from top of casing to the water level.

9. Record measurement to $0.01 \mathrm{ft}$. as Depth to Water (DTW) in field logbook.

10. Repeat steps 3-8, two to three times for consistency. Measurement should remain constant.

11. Pull M-scope from well.

12. Close and lock well cap.

E. Collection of water level measurements with steel or fiberglass tape.

1. Inspect tape and determine any measurement correction regnired for missing tape or applied length for "plopp.ri".

2. Lower measuring tape through well.

3. Iisten for the sound of the plopper" hitting the water.

4. Raise and lower the tape several times listening for precise point of contact, until confident the tape is just touching the surface of the water within the well casing. 
Method Number: ESP 302-1

Revision Number: 0

Date: August 29, 1988

Page: 5 of 7

MARTIN YARIETTA ENERGY SYSTEYS, INC

ENVIRONRENTAI SURVEILTANCE PROCEDURES

5. Read the tape to $0.01 \mathrm{ft}$. and record measurement in field logbook.

6. Repeat steps 2-5 above, measurements should remain constant within $0.01 \mathrm{ft}$.

7. Pull tape from well and decontaminate as specified in sampling and analytical plan, or refer to ESP900 .

8. Close and lock well cap.

9. Record information in logbook in accordance with ESP-500.

VIII. contamination control

Sampling tools, instruments and equipment will be protected from sources of contamination prior to use and decontaminated after use as specified in ESP-900. Liguids and materials from decontamination operations will be handled in accordance with ESP-1000. Sample containers will also be protected from sources of contamination. Sampling personnel will wear chemical resistant gloves when handing any samples. Gloves will be decontaminated or disposed between samples.

IX. $\quad$ OA $\angle O C$

In addition to adhering to the specific requirements of this sampling protocol and any supflementary sice specific procedures, the minimum QA/QC requirements for this sampling activity are the following.

\section{A. Control of Deviations}

When feasible, any departure from specified requirements will be justified and authorized prior to deviating from the requirements. Deviations will be sufficiently documented to allow repetition of the activity as actually performed. 
Method Number: ESP 302-1 Revision Number: 0

Date: August 29, 1988

Page: 6 of 7

\author{
MARTIN MARIETTA ENERGY SYSTEYS, INC \\ ENVIROMEENTAL SURVEILIANCE PROCEDURES
}

B. ec samples

The number and types of $Q C$ measurements and samples including duplicate measurements and samples, field blanks, equipment blanks and trip blanks will be collected or prepared as specified in the governing plans and procedures.

c. Verification

Verification activities are required of the above practices including surveillance and periodic record audits. These activities will be documented and become part of the completed project records.

Approved by:

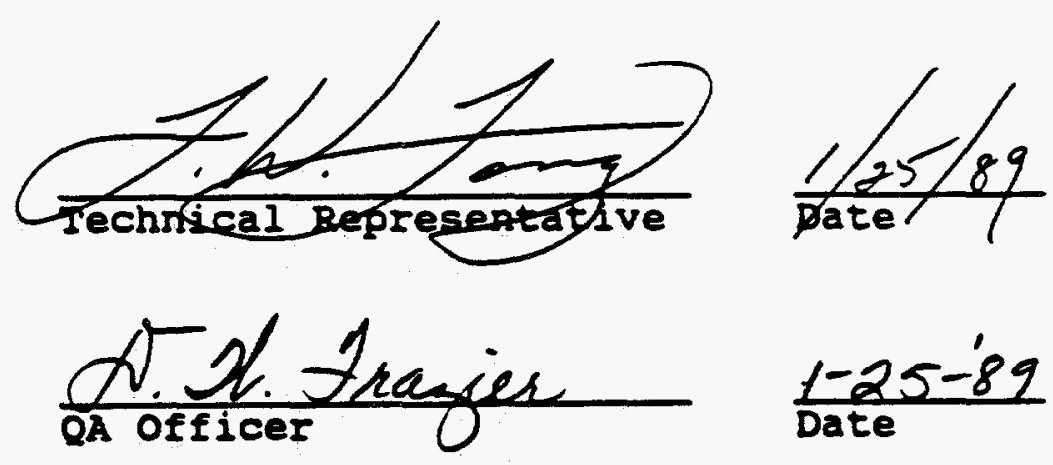


Yethod Number: ESP 302-1

Revision Number: 0

Date: August 29, 1988

Page: 7 of 7

MARTIN MARIETTA ENERGY SYSTEMS, INC

ENVIRONRENTAL SURVEILIANCE PROCEDURES

\begin{abstract}
ATPACFrTHIT I
SUBJECT: GROUNDWATER SAKPLING PROCEDURES: WATER LEVEL ILESURMIENTS USING WATER IEVEL INDICATOR
\end{abstract}

\title{
Field Checklist
}

Conducting probe $i . e ., K$-scope

steel or fiberglass tape measure with "plopper"

Keys to unlock wells

Logbook

Black Indelible Pen

Appropriate Containers

for Waste and Equipment

Gloves

safety shoes

Safety Glasses or Monogoggles

Health and safety Plan

Decontamination Equipment*

Sampling and Analysis Plan

Plastic sheeting

Manufacturer's Calibration and Instrument Manual

- See Section ESP-900 for decontamination procedures and equipment requirement. 
Method Number: ESP 302-2

Revision Number: 1

Date: January 31, 1990

Page: 1 of 7

MARTIN MARIETTA ENERGY SYSTEMS, INC.

ENVIRONMENTAL SURVEILLANCE PROCEDURES

SUBJECT: GROUNDWATER SAMPLING PROCEDURES: GUIDELINES FOR WELL PURGING

I. Scope and Application

The procedure covers the purging of water from a well prior to sampling so that the sample is representative of the formation groundwater. The device used (bailer or pump) depends upon aquifer properties, individual well construction and data quality objectives.

II. References

A. A Compendium of Superfund Field Operations Methods, EPA/540/P-87/001, U.S. Environmental Protection Agency, Washington, D.C., 1987.

B. Engineering Support Branch Standard Operating Procedures and Quality Assurance Manual, U.S. Environmental Protection Agency, Region IV, Athens, Georgia, April 1, 1986.

C. Sampling for Hazardous Materials, U.S. Environmental Protection Agency, Nov. 1984.

D. RCRA Groundwater Monitoring Technical Enforcement Guidance Document, OSWER-9950.1, Sept. 1986.

III. Summary of Method

Well construction information is gathered prior to beginning purging. Water level is measured to calculate the volume of water present in the well. Purging is completed using a calculated number of volumes and/or field measurements to determine the end point. 
Method Number: ESP 302-2

Revision Number: 1

Date: January 31, 1990

Page: 2 of 7

MARTIN MARIETTA ENERGY SYSTEMS, INC.

\section{ENVIRONMENTAL SURVEILLANCE PROCEDURES}

\section{Comments}

Rate of purging should be regulated to minimize agitation of the ground water. If using a bailer to purge the well, lower and raise it slowly so as not to agitate the water in the well. Water will be removed from top of water column.

Note: This procedure is complete when the manufacturers' calibration and maintenance instructions are attached.

V. Required Equipment and Apparatus
A. Bailer or pump as required by sampling and analysis plan.
B. Water level measurement equipment (See ESP 302-1)
C. Measuring tape
D. $\mathrm{pH} /$ Conductivity/Temperature measuring device

VI. Safety

It is Energy Systems' policy to maintain an effective program for control of employee exposure to chemical, radiological, and physical stress which is consistent with the requirements of Martin Marietta Corporation, DOE, and OSHA established standards and requirements. All Field personnel will be provided with appropriate protective clothing and safety equipment.

As a minimum, field personnel are required to wear steel capped safety shoes and safety glasses while performing this procedure. Refer to a site specific health and safety plan for detailed health and safety procedures. This plan should be reviewed prior to beginning work.

\section{YU. Qujunthos}


Method Number: ESP 302-2

Revision Number: 1

Date: January 31, 1990

Page: 3 of 7

MARTIN MARIETTA ENERGY SYSTEMS, INC.

ENVIRONMENTAL SURVEILLANCE PROCEDURES

VII. Procedures

A. Obtain the following information about well to be sampled.

- Well location

o Diameter(s) of well

- Depth of well

- Sereen interval(s)

- Information on waste management

B. Determine method to be used to purge well (i.e., pump or bailer).

C. Calibrate instruments according to manufacturer's instrument calibration and maintenance manual.

D. Locate well and record well number, site, date and well condition in logbook.

E. Unlock and open well after placing plastic sheeting on ground.

F. Collect water level measurements according to ESP 302-1.

G. Use known well depth information to determine the height of water column in well. Record all information in field log book.

H. Measure initial $\mathrm{pH} /$ specific conductance/temperature to evaluate water quality. 
Method Number: ESP 302-2

Revision Number: 1

Date: January 31, 1990

Page: 4 of 7

\section{MARTIN MARIETTA ENERGY SYSTEMS, INC. ENVIRONMENTAL SURVEILLANCE PROCEDURES}

I. Purge well of required volumes after calculating volume of water in well.

1. The formula for calculating the volume in gallons of water in the well casing or sections of telescoping well casing is as follows:

$\left(\pi r^{2} h\right) 7.481=$ gallons; where $\pi=3.142$

$r=$ radius of the well pipe in feet

$h=$ linear feet of water in well

7.481 = gallons per cubic foot of water

2. Calculation of the volume of water in typical well casings may be done as follows:

a. $2^{n}$ dia. well:

$0.1632 \mathrm{gal} / \mathrm{ft} x$ (linear $\mathrm{ft}$ of water) $=\mathrm{gal}$

b. $4^{\text {" dia. well: }}$

$0.6528 \mathrm{gal} / \mathrm{ft} \mathrm{x}$ (linear $\mathrm{ft}$ of water $)=$ gal.

c. $6^{\text {" dia. well: }}$

$1.4688 \mathrm{gal} / \mathrm{ft} \times$ (linear $\mathrm{ft}$ of water) $=\mathrm{gal}$.

J. The well purging end point will be determined with the use of field measurement such as $\mathrm{pH}$, specific conductance and/or temperature. Refer to proper ESP for each instrument used.

1. Purge one well volume, then begin measuring field parameters once during each well volume.

2. Purge a total of 3-5 well volumes (or more as specified in the sampling and analysis plan). Stop purging when field parameters have stabilized over two consecutive well volumes or the well is dry. 
Method Number: ESP 302-

Revision Number: 1

Date: January 31, 1990

Page: 5 of 7

MARTIN MARIETTA ENERGY SYSTEMS, INC.

ENVIRONMENTAL SURVEILLANCE PROCEDURES

3. Field parameters are considered stabilized when $\mathrm{pH}$ measurements agree within 0.5 units, temperature measurements agree within $1^{\circ} \mathrm{C}$ and specific conductance measurements are within 10 percent (i.e., 100 units for readings over 1000 umhos/cm).

4. If readings do not stabilize after five well volumes (or the number specified in the sampling and analysis plan) obtain additional guidance.

K. Purge 3-5 well volumes or to dryness only if sufficient water is not present to yield required purge volumes.

L. Record all purge times and rates of well evacuation in field log book.

M. When all necessary procedures are complete lock well, clean area and dispose of refuse, in accordance with guidelines set in ESP- 600 .

VIII. Contamination Control

Sampling tools, instruments and equipment will be protected from sources of contamination prior to use and decontaminated after use as specified in ESP900. Liquids and materials from decontamination operations will be handled in accordance with ESP-1000. Sampling personnel will wear chemical resistant gloves when handling any samples. Gloves will be decontaminated or disposed between samples.

IX. OA/OC

In addition to adhering to the specific requirements of this sampling protocol and any supplementary site specific procedures, the minimum QA/QC requirements for this sampling activity are the following. 
Method Number: ESP 302-2

Revision Number. 1

Date: January 31, 1990

Page: 6 of 7

MARTIN MARIETTA ENERGY SYSTEMS, INC.

ENVIRONMENTAL SURVEILLANCE PROCEDURES

\section{A. Control of Deviations}

When feasible, any departure from specified requirements will be justified and authorized prior to deviating from the requirements. Deviations will be sufficiently documented to allow repetition of the activity as actually performed.

\section{B. QC Samples}

The number and types of QC measurements and samples including duplicate measurements and samples, field blanks, equipment blanks and trip blanks will be collected or prepared as specified in the governing plans and procedures.

\section{Verification}

Verification activities are required of the above practices including surveillance and periodic record audits. These activities will be documented and become part of the completed project records.

Approved by:
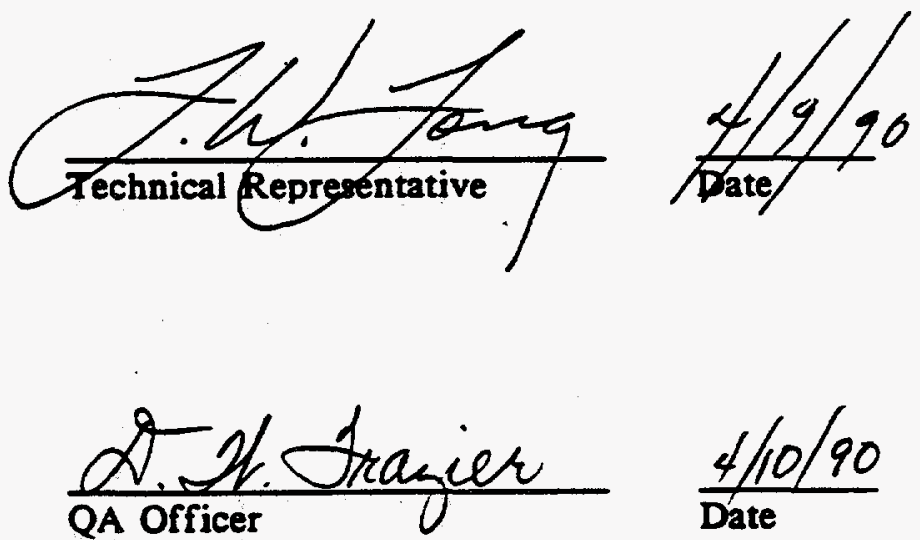
Method Number: ESP 302-

Revision Number: 1

Date: January 31, 1990

Page: 7 of 7

MARTIN MARIETTA ENERGY SYSTEMS, INC.

ENVIRONMENTAL SURVEILLANCE PROCEDURES

\section{ATTACHMENT I}

SUBJECT: GROUNDWATER SAMPLING PROCEDURES: GUIDELINES FOR WELL PURGING

Field Checklist

Bailer or Pump

Water Level Measurement

Equipment

Tape Measure

Logbook

$\mathrm{pH}$, Conductivity and

Temperature Measuring Devices

Sample Containers with Lids

Safety Glasses or Monogoggles

Gloves

Safety Shoes

Appropriate Containers for

Waste and Equipment

Black Indelible Pen

Sampling and Analysis Plan

Health and Safety Plan

Manufacturer's Instrument

Calibration and Maintenance Manual

Decontamination Equipment*

Plastic Sheeting

*See Section ESP-900 for decontamination procedures. 
Method Number: ESP 302-3

Revision Number : 0

Date: August 29, 1988

Page: 1 of 7

MARTIN MARIETTA ENERGY SYSTEMS, INC.

ENVIRONRENTAL SURVEILIANCE PROCEDURES

SUBJECT: GROUNDWATER SAMPLING PROCEDURES: USING A BAILFR

I. Scope and Apolication

This procedure describes the use of a bailer (hollow, cylindrical tube) for collecting groundwater samples. Groundwater samples may be used to obtain physical, chemical, or radiological data.

II. References

A. A Compendium of superfund Field operations Methods, EPA/540/P-87/001, U.S. Environmental Protection Agency, Washington, D.C., 1987.

B. Data ouality objectives for Remedial ActivitiesDevelopment Process, EPA/540/G-87/003, U.S. Environmental Protection Agency, Washington, D.C., 1987.

c. Test Methods for Evaluatina Solid Waste, SW-846, Volume II, Field Methods, Second Edition, U.S. Environmental Protection Agency, Washington, D.C., 1982.

D. Encineering Support Branch standard operating procedures and Ouality Assurance Manual, U.S. Environmental Protection Agency, Region IV, Athens, Georgia, April 1, 1986.

III. Sumnary of Method

A bailer is lowered by cord into the groundwater where it fills. The bailer is withdrawn, and its contents are drained into the appropriate containers. See Figure 1.

IV. Comments

A. Only bottom loading stainless steel or Teflon bailers will be used. 
Method Number: ESP 302-3

Revision Number : 0

Date: August 29, 1988

Rage: 2 of 7

MARTIN MARIETTA ENERGY SYSTEMS, INC.

ENVIRONMENTAL SURVEILLANCE PROCEDURES

B. Bailers are economical and convenient enough that a separate bailer may be dedicated to each well to minimize cross contamination. Dedicated bailers are stored in the well casing (typically above the water level) and are either used to purge the well or thrice rinsed with purged well water before the sample is taken.

c. Only unused, cleaned or dedicated cord will be used.

D. A reel upon which the cord may be wound is helpful in lowering and raising the bailer. It also reduces chance of contamination.

E. If purging is reguired refer to sampling and analysis plan and refer to ESP 302-2.

F. Bailers constructed with adhesive joints may not be used.

V. Required Equipment and Apparatus

A. Bailer - Constructed of stainless steel or Teflon and will be bottom loading. The sampling and analysis plan will typically specify appropriate size of bailer.

B. Cord - Compatible with analytes (i.e., stainless steel, Teflon, nylon, polyethylene). Materials are typically specified in the Sampling and Analysis plan. Braided cord will not be reused or decontaminated, but may be dedicated.

VI. Safety

It is Energy systems policy to maintain an effective program for control of employee exposure to chemical, radiological, and physical stress which is consistent with 7. 
Method Number: ESP 302-3

Revision Number : 0

Date: August 29, 1988

Page: 3 of 7

\section{MARTIN MARIETTA ENERGY SYSTEMS, INC.}

\section{ENVIRONRENTAL SURVEIIIANCE PROCEDURES}

the requirements of Martin Marietta Corporation, DOE, and OSHA established standards and requirements. All field personnel will be provided witi appropriate protective clothing and safety equipment.

As a minimum, field personnel are required to wear steel capped safety shoes, gloves and safety glasses while performing this procedure. Refer to a site specific health and safety plan for detailed health and safety procedures. This plan should be reviewed prior to beginning work.

VII. Procedures

A. Place plastic sheeting near well and work area.

B. Unlock and remove well cap, note condition of well and don clean gloves.

C. Record sampling station number, sample I.D., date, time, weather conditions, and any other well specific, pertinent information (i.e., water level, presence of product).

D. Remove clean bailer from protective covering or dedicated bailer from well casing, attach cord if necessary, allowing enough length for bailer to reach bottom of well.

E. Lower bailer slowly to the interval from which the sample is to be collected.

F. Allow bailer to fill with a minimum of surface disturbance in order to prevent sample water aeration.

G. Raise bailer to surface, feeding cord into container, reel or onto clean plastic sheeting. Do not allow bailer cord to contact ground. 
Method Number: ESP 302-3

Reyision Number : 0

Date: August 29, 1988

Page: 4 of 7

\begin{abstract}
YARTIN MARIETTA ENERGY SYSTEMS, INC.
\end{abstract}
ENVIROMLENTAL SURVEILIANCE PROCEDURES

H. Remove the cap from the sample bottle, and tilt the bottle slightly.

I. Pour the sample slowly down the inside of the sample bottle. Avoid splashing of the sample. Assure that any suspended matter in the sample is transferred quantitatively to the sample bottle.

J. Leave adequate air space in the bottle to allow for expansion, except for VOA flasks.

K. Label the bottle carefully, and clearly in accordance with ESP-500. Enter all information accurately, and check to be sure it is legible.

I. Samples will be placed in containers defined according to the needs, and then, when appropriate, packed with ice in coolers as soon as practical. Packaging, labeling, and preparation for shipment procedures will follow procedures as specified in ESP-800.

M. Complete field logbook and chain-of-custody forms in accordance with ESP -400 and ESP-500.

N. Replace bailer if dedicated, replace well cap and lock.

VIII. Sontamination control

Sampling tools, instruments and equipment will be protected frim sources of contamination prior to use and decontaminated after use as specified in ESP-900. Liquids and materials from decontamination operations will be handled in accordance with ESP-1000. Sample containers will also be protected from sources of contamination. sampling personnel will wear chemical resistant gloves when handling any samples. Gloves will be decontaminated or disposed between samples. 
Method Number: ESP 302-3

Revision Number : 0

Date: August 29, 1988

Page: 5 of 7

\begin{abstract}
MARTIN MARIETTA ENERGY SYSTEMS, INC.
\end{abstract}
ENVIRONLENTAL SURVEIIIANCE PROCEDURES

IX. OA/OC

In addition to adhering to the specific requirements of this sampling protocol and any supplementary site specific procedures, the minimum $Q A / Q C$ requirements for this sampling activity are the following.

A. Control of Deviations

When feasible, any departure from specified requirements will be justified and authorized prior to deviating from the requirements. Deviations will be sufficiently documented to allow repetition of the activity as actually performed.

B. oc samples

The number and types of $Q C$ measurements and samples including duplicate measurements and samples, field blanks, equipment blanks and trip blanks will be collected or prepared as specified in the governing plans and procedures.

\title{
c. Verification
}

Verification activities are required of the above practices including surveillance and periodic record audits. These activities will be documented and become part of the completed project records.

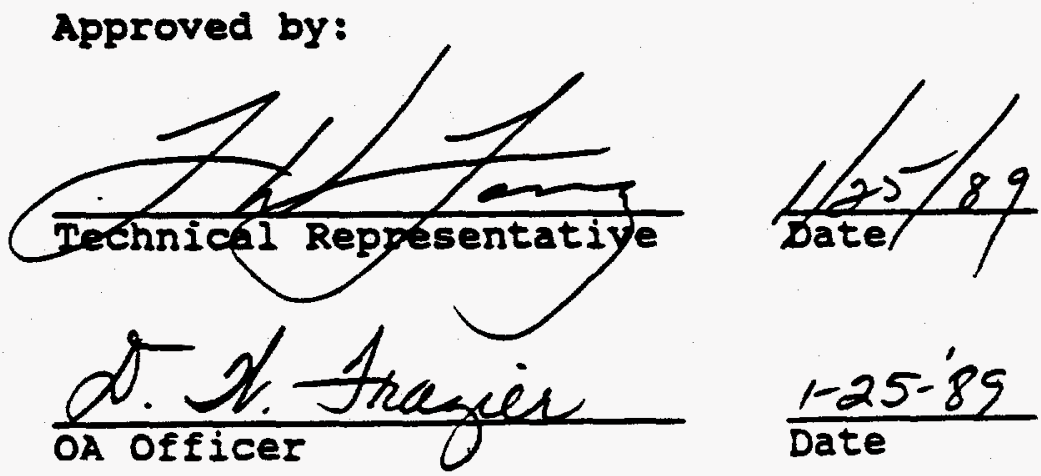


Method Number: ESP 302-3

Revision Number: 0

Date: August 29, 1988

Page: 6 of 7

MARTIN MARIETTA ENERGY SYSTEMS, INC.

ENVIRONMENTAL SURVEILIANCE PROCEDURES

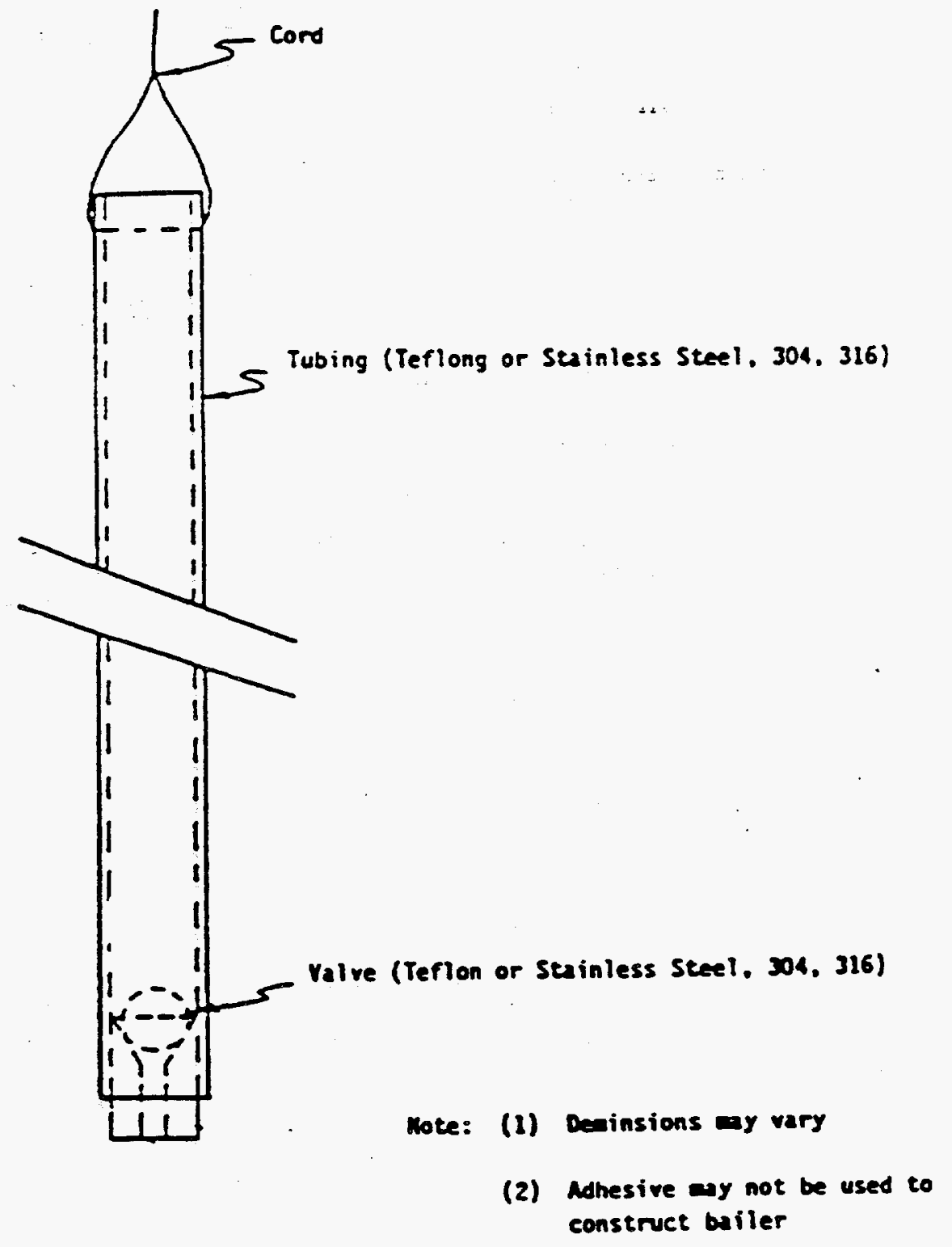

Figure 1

Typical Bottom Loading Bailer 
Method Number: ESP 302-3

Revision Number : 0

Date: August 29, 1988

Page: 7 of 7

MARTIN MARIETTA ENERGY SYSTEMS, INC.

ENVIRONIENTAL SURVEILIANCE PROCEDURES

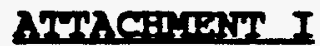

SUBJECT: GROUNDWATER SAMPLING PROCEDURES: USING A BAILER

Field Checklist

Bailer (Stainless steel
or Teflon and Bottor Loading)
Container, Reel or Plastic
Sheeting to collect Cord
Cord*
Iogbook
Sample containers with Lids
Safety Glasses or Monogoggles
Gloves
Safety shoes, if required
Ice/Cooler, as required
Custody seals, as required
Chain-of-custody Forms
Plastic sheeting

Black Indelible Pen

Labels

Sampling and Analysis Plan

Health and Safety Plan

Decontamination Equipment* *

Lab Wipes

Appropriate

Containers for Waste and Equipment

* Refer to Sampling and Analysis Plan for approved material.

* See Section ESP-900 for decontamination procedures and equipment requirements. 
Method Number: ESP 302-5

Revision Number: 0

Date: August 29, 1988

Page: 1 of 7

MARTIN MARIETTA ENERGY SYSTEMS, INC.

ENVIRONEENTAL SURVEILIANCE PROCEDURES

SUBJECT: GROUNDWATER SAMPIE PROCEDURES: USING A BLADDER PUMP

I. Scope and Apolication

This procedure discusses collection of groundwater samples using the bladder pump. The water samples may be used to obtain physical, chemical, or radiological data.

II. References

A. A Compendium of superfund Field operations Methods, EPA/540/P-87/001, U.S. Environmental Protection Agency, Washington, D.C., 1987.

B. Engineering support Branch standard operating Procedures and Quality Assurance Manual, U.S. Environmental Protection Agency, Region IV Environmental Service Division, Georgia, April 1, 1986.

C. RCRA Ground Water Monitoring Technical Enforcement Guidance Document, OSWER-9950.1, September 1986.

D. Test Methods for Evaluating Solid Waste, SW-846, Volume II, Field Methods, second Edition, U.S. Environmental Protection Agency, Washington, D.C., 1982.

III. Summary of Method

A bladder pump is either dedicated to a well, or clraned before use. The pump is placed in thit well pric: to sample collection. A compressed air source forces air through a control box which regulates timed intervals of air discharges into, and air escapes from, the bladder pump, along with air intake pressure. The bladder expands and contracts with air intake and escape, and thereby forces water to the head of the well where it is collected. 
Method Number: ESP 302-5

Revision Number: 0

Date: August 29, 1988

Page: 2 of 7

MARTIN MARIETTA ENERGY SYSTEMS, INC.

ENVIRONIENTAL SURVEILIANCE PROCEDURES

IV. comments

Because there is little aeration or agitation of the water, the bladder pump can be used to collect samples for volatile organic analysis.

Note: This procedure is complete when the manufacturers' calibration and maintenance instructions are attached.

v. Required Equipment and Apparatus

A. Bladder pump with Teflon bladder and stainless steel case.

B. Control Box

c. Compressed Gas Source

D. Electrical Source (if necessary)

E. Regulators

F. Air lines

VI. Safety

It is Energy systems' policy to maintain an effective program for control of employee exposure to chemical, radiological, and physical stress which is consistent with the requirements of Martin Marietta Corporation, DOE, and OSHA established standards and requirements. يli Field personnel will be provided with appropriate protective clothing and safety equipment.

As a minimum, field personnel are required to wear steel capped safety shoes and safety glasses while performing this procedure. Refer to a site specific health and safety plan for detailed health and safety procedures. This plan should be reviewed prior to beginning work. 
Method Number: ESP 302-5

Revision Number: 0

Date: August 29, 1988

Pace: 3 of 7

MARTIN MARIETTA ENERGY SYSTEMS, INC.

ENVIRONRENTAL SURVEILTANCE PROCEDURES

VII. Procedures

A. Locate well and record well number, site, date, and well condition in logbook.

B. Use plastic sheeting as necessary to prevent equipment from coming in contact with potentially contaminated surfaces.

C. Unlock and open well.

D. Collect water level measurements by method outlined in ESP 302-1, and record in logbook.

E. Attach air lines, sample lines and lifting lines to pump. Iifting lines should bear the weight of the pump with air and sample lines attached to lifting lines approximately every 10 feet with appropriate inert devices.

F. Lower pump in well to desired level, if pump is not dedicated.

G. Connect air lines from regulated compressed gas source to control box.

H. Connect battery, if required.

I. start air flow.

J. Adjust flow rate with throttle knob found on control box.

K. To control discharge and refill cycle rate of the bladder, use the discharge and refill control knobs located on control box.

I. Equal length discharge and refill cycles are generally desirable, but individual well conditions may dictate otherwise. 
Kethod Number: ESP 302-5

Revision Number: 0

Date: August 29, 1988

Page: 4 of 7

MARTIN MARIETTA ENERGY SYSTEMS, INC.

ENVIRONLENTAL SURVEILTANCE PROCEDURES

4. Then a bladder pump is used for purging, measure the amount of water discharged with a container of knowl. volume, and calculate purge time for the required purge volume. Refer to ESP 302-2.

N. Obtain and record required measurements of the well water, (i.e., specific conductance, temperature and other measurement as required by the sampling and Analysis Plan); refer to ESP 307 series.

o. Remove the cap from the sample bottle, and tilt the bottle slightly.

P. Pour the sample slowly down the inside of the sample bottle. Avoid splashing the sample. Assure that any suspended matter in the sample is transferred quantitatively to the sample bottle.

Q. Leave adequate air space in the bottle to allow for expansion, except for vOA vials which are filled to overflowing and capped.

R. Label the bottle carefully, and clearly in accordance with ESP-500. Enter all information accurately, and check to be sure it is legible.

s. Samples will be placed in containers defined according to the needs, and then, when appropriate, packed with ice in coolers as soon as practical. Packaging, labeling, and preparation for shipment procedures will follow procedures as specified in ESP-800.

T. Complete field logbook and chain-of-custody forms in accordance with ESP-400 and ESP-500.

U. If pump not dedicated, remove from well.

V. Replace well cap and lock. 
Method Number: ESP 302-5

Revision Number: 0

Date: August 29, 1988

Page: 5 of 7

MARTIN MARIETTA ENERGY SYSTEMS, INC.

ENVIRONIENTAL SURVEIILANCE PROCEDURES

VIII. Sontamination control

Sampling tools, instruments and equipment will be protected from sources of contamination prior to use and decontaminated after use as specified in ESP-900. Liquids and materials from decontamination operations will be handled in accordance with ESP-1000. Sample containers will also be protected from sources of contamination. sampling personnel will wear chemical resistant gloves when handling any samples. Gloves will be decontaminated or disposed between samples.

IX. $\quad Q A O C$

In addition to adhering to the specific requirements of this sampling protocol and any supplementary site specific procedures, the minimum $Q A / Q C$ requirements for this sampling activity are the following.

A. Control of Deviations

When feasible, any departure from specified requirements will be justified and authorized prior to deviating from the reguirements. Deviations will be sufficiently documented to allow repetition of the activity as actually performed.

B. Oc samoles

The number and types of $Q C$ measurements and samples including duplicate measurements and samples, field blanks, equipment blanks and trip blanks will be collected or prepared as specified in the governing plans and procedures. 
Method Number: ESP 302-5

Revision Number: 0

Date: August 29, 1988

Page: 6 of 7

\section{MARTIN MARIETTA ENERGY SYSTEMS, INC.}

ENVIRONRENTAL SURVEIIIANCE PROCEDURES

\section{c. Verification}

Verification activities are required of the above practices including surveillance and periodic record audits. These activities will be documented and become part of the completed project records.

Approved by:
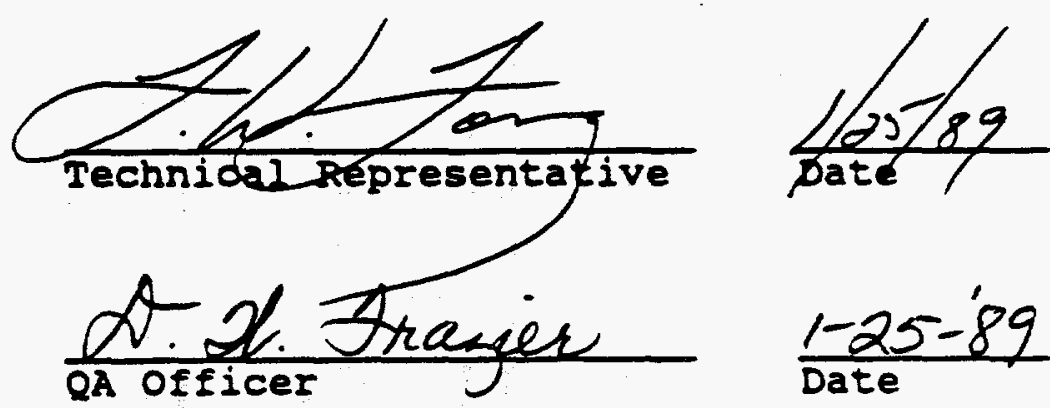
Kethod Number: ESP 302-5

Revision Number: 0

Date: August 29, 1988

Page: 7 of 7

IARTIN MARIEITA ENERGY SYSTEMS, INC.

ENVIRONYENTAL SURVEIITANCE PROCEDURES

ATMACDIETT I

SUBJECT: GROUNDWATER SAMPIE PROCEDIIRES: USING A BLADDER PUMP

\section{Field Checklist}

Bladder Pump with Teflon

Bladder and Stainless Steel

Case

Regulators

Control Box

Air Line

Compressed Gas source

Electrical source, if required

Iogbook

Sample containers with Lids

Safety Glasses or Monogoggles

Gloves

Safety Shoes

Ke! $s$ for Well Lock

Ice/cooler, as required

Custody seals, as required

Chain-of-Custody Forms

Chemical Preservatives,

as required
Black Indelible Pen

Labels

Sampling and

Aralysis Plan

Health and Safety Plan

Decontamination Equipment *

Lab Wipes

Appropriate Container for Waste and Equipment

Plastic sheet

Container (e.g., bucket) of known volume.

Manufacturer's Calibration and Instruction Manual

* See Section ESP-900 for decontamination procedures and equipment requirements. 
Method No: ESP-500

Revision: 1

Date: January 31, 1990

Page: 1 of 8

MARTIN MARIETTA ENERGY SYSTEM, INC.

ENVIRONMENTAL SURVEILLANCE PROCEDURES

\section{SUBJECT: MANUAL CHAIN OF CUSTODY PROCEDURES}

I. Scope and Apolication

This procedure applies to samples collected under Martin Marietta Energy Systems, Inc. (Energy Systems) environmental sampling activities. The goal is to ensure the integrity of the samples from collection to final disposition by documenting possession. The documentation will trace possession of samples from their collection through all transfers of custody until final disposition, including archiving where required.

II. References

A. Test Method for Evaluating Solid Waste, SW-846, Second Edition, U.S. Environmental Protection Agency, Washington, D.C., 1982.

B. RCRA Ground-Water Monitoring Technical Enforcement Guidance Document (TEGD), OSWER-9950.1, U.S. Environmental Protection Agency, Washington, D.C., 1986.

C. A Compendium of Superfund Field Operations Methods, EPA/540/P-87/001, U.S. Environmental Protection Agency, Washington, D.C., 1987.

D. Engineering Support Branch Standard Operating Procedures and Ouality Assurance Manual, U.S. Environmental Protection Agency, Athens, GA, 1986.

E. The Environmental Survey Manual, DOE/EH-0053, Appendix E, Field Sampling Protocols and Guidance, U.S. Department of Energy, 1987.

F. NEIC Manual for Groundwater/Subsurface Investigations at Hazardous Waste Sites, EPA-330/9-81/002, July 1981.

III. Summary of Method

Chain-of-custody is a procedure for tracking of samples. The components of Energy Systems chain-of-custody are: sample labels or tags, sample seais, field logbooks, chain-of-custody records, sample requests for analysis, and laboratory chain-of-custody sheets. Each document is filled out to transmit appropriate data and to track the sample. 
Method No: ESP-500

Revision: 1

Date: January 31,1990

Page: 2 of 8

MARTIN MARIETTA ENERGY SYSTEM, INC.

ENVIRONMENTAL SURVEILLANCE PROCEDURES

\section{Comments}

A. This procedure will be applied to field samples collected under Energy Systems field studies, including archival samples. Chain-of-custody procedures are not required for transfer of samples between sampling team members.

B. The project designation and sampling location may be eliminated from the label and documented in a logbook if necessary to protect sensitive data or transmit blind QC samples.

V. Equipment Required

A. Sample labels or tags

B. Sample seals

C. Field logbook

D. Chain-of-custody record

E. Sample request for analysis

F: Laboratory chain-of-custody sheet

VI. Safety

N/A.

VII. Procedure

A. Samoles Under Custody

Chain-of-custody requirements are necessary whenever a sample leaves the sampling team's custody. A sample is considered to be under a persons custody if any of the following conditions are met:

1. The sample is in the persons physical possession;

2. The sample is in line of sight of the person after he/she has taken possession;

3. The sample is secured by that person so any tampering can be detected;

4. A sample is secured by the person in possession, in an area which only authorized personnel can enter. 
Method No: ESP-500

Revision: 1

Date: January 31,1990

Page: 3 of 8

MARTIN MARIETTA ENERGY SYSTEM, INC.

\section{ENVIRONMENTAL SURVEILLANCE PROCEDURES}

\section{B. Sample Labels or Tags}

Sample labels will be affixed to all sample containers prior to or at the time of sampling. To the extent practicable, sample bottles will be labeled prior to filling. Sample labels will be waterproof paper or plastic with gummed backs or waterproof tags, as appropriate. Labels will be completed with black indelibie ink and will include the following information:

1. Unique field study or sampling activity name and/or number (see comment IV.B for exception);

2. Unique sample number;

3. Sample location or appropriate identification as identified in the sampling program;

4. Sampling date and time (see comment IV.B for exception);

5. Sample preservation used;

6. Media sample or sample type;

7. Analyses required.

8. Comments and special precautions as needed.

\section{Samole Seals}

Sample seals are used to detect tampering of samples, following sample collection prior to the time of analysis. The seal will be attached in such a way that it is necessary to break the seal in order to open the sample container. Here, "sample containers" may refer to either individual sample containers or a shipping container such as an ice chest. Seals will be affixed to the containers before they leave the custody of the sampling personnel.

Sample seals will be waterproof paper or plastic with gummed backs. All samples designated for shipment which leaves the sampler's custody will have a sample seal affixed which includes the following information: 
Method No: ESP-500

Revision: 1

Date: January 31, 1990

Page: 4 of 8

MARTIN MARIETTA ENERGY SYSTEM, INC.

ENVIRONMENTAL SURVEILLANCE PROCEDURES

1. Unique sample identification (same as VII.B.2, above);

2. Name(s) of collector(s);

3. Date and time of sampling (see comment IV.B for exception);

4. Sample location or identification (see comment IV.B for exception).

Alternately, evidence tape with collector's initials, date and time may be used.

D. Field Logbook

A field logbook entry will be made at the time the sample is taken; the entry will be completed at the time the sample is taken. The field logbook entry will include, but not limited to, the following information:

1. Unique field study or sampling activity name and number and sample number;

2. Volume of sample taken;

3. Name(s) of collector(s) and identification of others present;

4. Name and address of field contact, as appropriate;

5. Date and time of sample collection;

6. Sample depth or interval;

7. Suspected waste composition, including concentrations, as appropriate;

8. Analytical parameter(s) to be measured;

9. Type of process that produced waste (if known);

10. Sample media (e.8., water, wastewater, sludge, or soil);

11. Preservative; 
Method No: ESP-500

Revision: 1

Date: January 31,1990

Page: 5 of 8

MARTIN MARIETTA ENERGY SYSTEM, INC.

ENVIRONMENTAL SURVEILLANCE PROCEDURES

12. Location of sampling point (e.g., field or building coordinates of sample location, grid number, well number, etc.);

13. Producer of waste and address if different from location, as appropriate;

14. Designation of QC samples (e.g., blank, splits or duplicates);

15. Sampling methodology;

16. Observations during sampling (e.g., odors, colors and textures);

17. References, such as maps or photographs;

18. Chain-of-Custody control number and sample request documentation;

19. Sample distribution and how transported;

20. Initials of responsible observer;

21. Field observations and measurements.

E. Chain-of-Custody Records

The chain-of-custody record will be completed by the sampling personnel at the time of the sampling event. The record(s) will be signed as relinquished or received each time the sample changes possession, from collection to final deposition. The chain-of-custody record will include the following information.

1. Unique sample number(s);

2. Unique field study or sampling activity name and/or number (see comment IV.B for exception);

3. Date and time of sample collection (see comment IV.B for exception); 
Method No: ESP-500

Revision: 1

Date: January 31,1990

Page: 6 of 8

MARTIN MARIETTA ENERGY SYSTEM, INC.

\section{ENVIRONMENTAL SURVEILLANCE PROCEDURES}

4. Place and address of collection (see comment IV.B for exception);

5. Name(s) of sample team member(s);

6. Signature(s) of the collector(s) or field sample custodian;

7. Laboratory destination, if known;

8. Waste type, if known;

9. Container type;

10. Condition of sample on receipt;

11. Possible sample hazards;

12. Chain-of-custody control number;

13. A corresponding sample request for analysis sheet number or other identification;

14. Signature and date blocks for personnel relinquishing or receiving sample custody;

15. Inclusive dates of possession.

\section{F. Sample Request for Analysis Sheet}

A request for analysis sheet will be submitted to the lab for the collected samples. The request for analysis sheet or a copy of the chain-of-custody will provide the following information:

1. Unique sample number(s);

2. Laboratory sample number (may be assigned by lab personnel);

3. Unique field study or sampling activity name and number (see comment IV.B for exception);

4. Contact person and phone number to whom data is to be reported; 
Method No: ESP-500

Revision: 1

Date: January 31, 1990

Page: 7 of 8

MARTIN MARIETTA ENERGY SYSTEM, INC.

ENVIRONMENTAL SURVEILLANCE PROCEDURES

5. Date and time of sample collection (see comment IV.B for exception);

6. Sample type;

7. Type(s) of analysis requested;

8. Signature(s) of person receiving the sample;

9. Date and time of sample receipt;

10. Sample Destination.

G. Laboratory Chain-of-Custody Sheet

The laboratory chain-of-custody sheet will be completed by the laboratory personnel receiving custody of the field samples. The laboratory chain-ofcustody sheet may be a separate document or part of a multicopy form used for both field and laboratory activity.

The laboratory personnel will verify that information on the appropriate form is complete and accurate. He/she will verify that the sample was received with all pertinent information and that the integrity of the sampie(s) has been maintained. The laboratory chain-of-custody sheet will include the following information:

1. Unique field study or sampling activity name and/or number (see comment IV.B for exception);

2. Unique sample number;

3. Unique laboratory $\log$-in number;

4. Verification of the presence of all appropriate forms and their completion;

5. Inspection comments of the samples by the receiving sample custodian;

6. Time and date of receipt;

7. Signature(s) of receiving personnel; 
Method No: ESP-500

Revision: 1

Date: January 31, 1990

Page: 8 of 8

MARTIN MARIETTA ENERGY SYSTEM, INC.

\section{ENVIRONMENTAL SURVEILLANCE PROCEDURES}

8. Signature blocks for relinquishing and receiving sample possession within the laboratory or laboratories;

9. Date and time for relinquishing and receiving;

10. Sample allocation;

11. Final sample disposition.

VIII. Contamination Control

N/A.

IX. $\mathrm{OA} / \mathrm{OC}$

A. Verification

Verification activities are required of the above practices including surveillance and periodic record audits. These activities will be documented and become part of the completed project records.

B. Documentation

A bound field notebook will be maintained by the sampling team to provide daily records of significant events, observations, records, and measurements. All entries will be made in black, indelible ink, signed, and dated. Subsequent corrections will be made by a single line drawn through the original entry, entry of the corrected information, and initialing and dating by the individual making the correction.

Copies of completed chain-of-custody records and laboratory request for analysis sheets will be retained and become part of the completed project records.
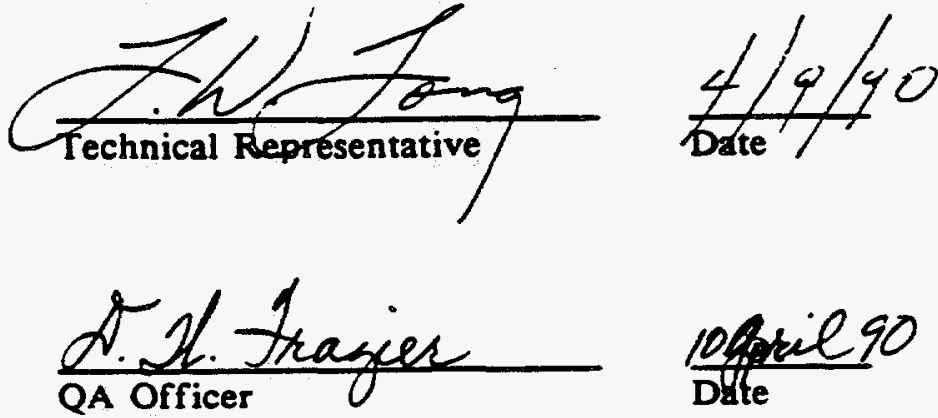
Method No.: ESP-701

Revision No.: 0

Date: August 26, 1988

Page: 1 of 4

MARTIN MARIETTA ENERGY SYSTEMS, INC.

ENVIRONMENTAL SURVEILLANCE PROCEDURES

\section{SUBJECT: SAMPLE PRESERVATION AND CONTAINER MATERIALS}

\section{Scope and Application}

This procedure provides guidance on preservation methods, holding times, storage conditions and container materials.

\section{References}

A. Environmental Survey Manual, DOE/EH-0053, U.S. Department of Energy, Washington, D.C., 1987.

B. Engineering Support Branch Standard Operating Procedures and Quality Assurance Manual, U.S. Environmental Protection Agency, Athens, GA, 1986.

C. A Compendium of Superfund Field Operations Methods, EPA/540/P87/001, U.S. Environmental Protection Agency, Washington D.C., 1987.

D. Data Oual ity Objectives for Remedial Response Activities, EPA/540/G87/003, U.S. Environmental Protection Agency, Washington, D.C., 1987.

E. Handbook for Sampling and Sample Preservation of Water and Wastewater, EPA-600/4-82-029, U.S. Environmental Protection Agency, EMSL-Cincinnati, 1982.

F. Guidelines Establishing Test Procedures for the Analysis of Pollutants Under the Clean Water Act, Federal Register, Volume 44, 40 CER Part 136.

\section{Summary of Method}

Methods of preservation are relatively limited and are generally intended to extend holding times by: 1) retarding biological action; 2) retarding hydrolysis of chemical compounds and complexes; and 3) reducing volatility of constituents.

Preservation methods are generally limited to chemical addition, $\mathrm{pH}$ control, refrigeration, freezing and protection from light. Combinations of these methods are often used for the preservation of the sample. 
Method No.: ESP-701

Revision No.: 0

Date: August 25, 1988

Page: 2 of 4

MARTIN MARIETTA ENERGY SYSTEMS, INC.

ENVIRONMENTAL SURVEILLANCE PROCEDURES

\section{A. Chemical Addition}

The most convenient preservative is a chemical which can be added to a sample bottle prior to sampling. When the sample is added, the preservative disperses immediately, stabilizing the parameter(s) of concern for long periods of time. when the preservative added interferes with other parameters being measured, additional samples for those parameters must be collected. For example, concentrated nitric acid added for the preservation of some of the metals would interfere with BOD, so an additional sample must be collected for BOD.

B. pH Control

$\mathrm{pH}$ control to preserve the sample is dependent upon chemical addition. As an example, to keep metal ions in a dissolved state, concentrated nitric acid is added to lower the $\mathrm{pH}$ to less than 2.

C. Freezing

Freezing is a method used for increasing the holding time and allowing collection of a single sample for all analyses. However, the residue solids components (filterable and nonfilterable) of the sample change with freezing and thawing. Therefore, return to equilibrium and then high speed homogenization is necessary before any analysis can be run. This method may be acceptable for certain analysis but not as a general preservation method.

D. Refrigeration

This is a common method used in field work and has no detrimental effect on sample composition. Although it c'ses not maintain integrity for all parameters, it does not iriterfers with any analytical methods.

\section{E. Protection from Light}

Some parameters are subject to change or degradation when exposed to light. Such samples are protected by the use of amber containers, black wrapping, or foil.

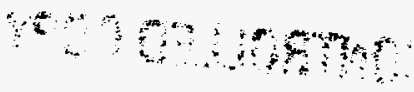


Method No.: ESP-701

Revision No.: 0

Date: August 25, 1988

Page: 3 of 4

MARTIN MARIETTA ENERGY SYSTEMS, INC.

ENVIRONMENTAL SURVEILLANCE PROCEDURES

\section{Comments}

Complete preservation of samples, either domestic sewage, industrial wastes, or natural waters, is a practical impossibility. Regardless of the nature of the sample, complete stability for every constituent can never be achieved. At best, preservation techniques can only retard the chemical and biological changes that take place in a sample after the sample is removed from the parent source. To maintain the integrity of the sample, appropriate selection of containers, pretreatment of containers if necessary and the holding times form the integral part of the sample preservation program. For NPDES samples, the permit holder must use specific preservatives if the sample cannot be analyzed immediately after collection. See Reference $F$ for details.

V. Required Equipment and Apparatus

May include but are not 1 imited to the following.

Nitric acid, American Chemical Society (ACS) grade, $16 \mathrm{~N}$

Sodium hydroxide, ACS grade pellets

Sulfuric acid, ACS grade, $37 N$

Hydrochloric acid, ACS grade, $12 \mathrm{~N}$

Sodium thiosulfate, ACS grade, cystalline

Mercuric chloride, ACS grade, powder

\section{Safety}

Field work shall be performed using the methods as discussed in ESP-300.

Preservatives include acids and bases added to modify the $\mathrm{pH}$ of a sample. Sample collectors must take care to avoid tipping and overfilling sample jars containing preservatives too minimize potential skin contact.

\section{Procedures}

See Table 1 for recommended sample containers, sample preservation, and sample holding times. Sample volumes listed are for guidance purposes only and are dependent on the method of analysis and the QC protocol employed. The receiving laboratory should be contacted for their specific needs. 
Method No.: ESP-701

Revision No.: 0

Date: August 25, 1988

Page: 4 of 4

MARTIN MARIETTA ENERGY SYSTEMS, INC.

ENVIRONMENTAL SURVEILLANCE PROCEDURES

\section{VIII.Contamination Control}

Sample containers will be delivered to the site tightly capped and cleaned to minimize the need to expose the interior of the sample containers to ambient field conditions prior to obtaining a sample. Fresh reagants needed for preservation will be prepared as necessary.

IX. QA/OC

Reagant blanks : may be analyzed to ensure that preservatives meet specifications. 
TABLE $1^{1}$

RECOMMENDED SAMPLE CONTAINERS, SAMPLE PRESERVATION, AND SAMPLE HOLDING TIMES

Parameter

\section{Concentrated raste Samples}

\section{Organic compounds}

Metals and other

Inorganic Compounds

EP Toxicity

Flash point and/or

Heat Content

\section{Fish Samples}

Organic Compounds

Metals and other

Inorganic Compounds

\section{Container}

8-oz. widemouth glass

8-oz. widemouth glass

with Teflon liner

8-oz. widemouth glass

with Teflon liner

8-oz. widemouth glass

with Teflon liner

Wrap in alumimum foil

Place in plastic ziplock bag

\section{Liouid - Iow to Fedium Conoentration Samples}

Alkalinity

Acidity

Bacteriological 500-ml or 1-1iter poly-2 ethylene with polyethylene

or polyethylene lined closure

$500-\mathrm{ml}$ or $1-1$ iter poly-2 ethylene with polyethylene

or polyethylene lined closure

250-ml glass with glass

closure or plastic capable

of being autoclaved
Preservative

Holding

Time

$\begin{array}{ll}\begin{array}{l}\text { None } \\ \text { None }\end{array} & \text { ASAP } \\ \text { None } & \text { ASAP - NS } \\ \text { None } & \text { ASAP - NS }\end{array}$

Freeze

ASAP

Freeze

ASAP

$\mathrm{CoOl}, 4^{\circ} \mathrm{C}$

14 days

Cool, $4^{\circ} \mathrm{C}$

14 days

Cool, $4^{\circ} \mathrm{C}$

6 hrs. 
TABLE 1 (continued)

RECOMMENDED SAMPLE CONTAINERS, SAMPLE PRESERVATION, AND SAMPLE HOIDING TIMES

Parameter

Container

Iiquid - Iow to Yedium Oanaentration Samples (Oantinuad)

Static Bioassay

Biochemical oxygen

Demand (BOD)

chloride

Chlorine Residual

Color

Conductivity

Chromium, Hexavalent

Cyanide 1-gal. amber glass

(not solvent rinsed)

1/2-gal. polyethylene ${ }^{2}$

with polyethylene closure

500-ml or 1-1iter poly-2 ethylene with polyethylene or polyethylene lined closure

In-situ, beaker or bucket

500-ml or 1-1iter poly-2 ethylene with polyethylene

or polyethylene lined closure

500-ml or 1-1iter poly ${ }^{2}$ ethylene with polyethylene or polyethylene lined closure

1-liter polyethylene with polyethylene closure

1-1iter or $1 / 2$-gallon polyethylene with polyethylene or polyethylene lined closure
Preservative

Holding Time

\begin{tabular}{|c|c|}
\hline $\mathrm{CoOl}, 4^{\circ} \mathrm{C}$ & $48 \mathrm{hrs.}$ \\
\hline $\mathrm{CoOl}, 4^{\circ} \mathrm{C}$ & $48 \mathrm{hrs}$. \\
\hline None & 28 days \\
\hline None & $\begin{array}{l}\text { Analyze } \\
\text { Immediately }\end{array}$ \\
\hline $\mathrm{CoOl}, 4^{\circ} \mathrm{C}$ & 48 hrs. \\
\hline $\mathrm{CoOl}, 4^{\circ} \mathrm{C}$ & $\begin{array}{l}28 \text { days } \\
\text { (determine on } \\
\text { site if possible) }\end{array}$ \\
\hline $\mathrm{CoOl}, 4^{\circ} \mathrm{C}$ & 24 hrs. \\
\hline $\begin{array}{l}\text { Ascorbic Acid } 3,4 \\
\text { Sodium Hydroxide, } \\
\text { pH }>12 \\
\text { Cool, } 4^{\circ} \mathrm{C}\end{array}$ & 14 days \\
\hline
\end{tabular}


TABLE 1 (continued)

RECOMMENDED SAMPLE CONTAINERS, SAMPLE PRESERVATION, AND SAMPLE HOLDING TTMES

Parameter

Container

\section{Liquid - Iow to Fediun conoentration Samples (Oantinued)}

\section{Dissolved oxygen}

(Probe)

\section{Dissolved oxygen}

(Winkler)

EP Toxicity

Fluoride

Hardness

LAS

Metals

Metals, Dissolved
In-situ, beaker or bucket

300-ml glass, BOD bottle

1-gal. glass (amber) with Teflon liner

1-liter polyethylene or ${ }^{2}$ $1 / 2$-gal. polyethylene with polyethylene or polyethylene lined closure

500-ml or 1-liter polyethylene with polyethylene or polyethylene lined closure

500-ml or 1-1iter poly-2 ethylene with polyethylene or polyethylene lined closure

1-1iter polyethylene with polyethylene lined closure

1-liter polyethylene with polyethylene lined closure
Preservative

Holding

Time

None

Determine On Site

Fix on site, store in dark

Cool, $4^{\circ} \mathrm{C}$

8 hrs. (determine on site if possible)

ASAP - NS

None

28 days

50\% Nitric $^{3}$ Acid, $\mathrm{pH}<2$

6 months

$\mathrm{CoOl}, 4^{\circ} \mathrm{C}$

48 hrs.

508 Nitric $^{3}$

Acid, $\mathrm{pH}<2$

Filter-on-site ${ }^{3}$

50\% Nitrate

Acid, $\mathrm{pH}<2$
6 months

6 months 
TABLE 1 (continued)

RECOMMENDED SAMPLE CONTATNERS, SAMPIE PRESERVATION, AND SAMPLE HOLDTNG TTMES

Parameter

Container

Preservative

Holding

Time

\section{Iiquid - Ion to Madium cancentration Samples (Oontinued)}

Nutrients 4

Oil and grease

Organic Compounds -

Extractable and

Pesticide Scan

No resicual chlorine

Present

Residual Chlorine

Present

Organic Compounds Purgeable (VOA)

No Residual chlorine Present

No Residual chlorine Present 1-1iter polyethylene or 1/2-gal. polyethylene with polyethylene or polyethylene lined closure

\section{1-1iter widemouth glass} with Teflon liner

1-gal. amber glass or 2 1/2-gal. amber glass with Teflon liner

1-gal. amber glass or 2 1/2-gal. amber glass with Teflon liner

2 40-ml vials with

Teflon Lined Septum caps

2 40-ml vials with

Teflon lined septum caps

$$
\begin{aligned}
& 50 \% \text { sulfuric } \\
& \text { acid, pH }<2 \\
& \text { cool, } 4^{\circ} \mathrm{C}
\end{aligned}
$$

$$
\begin{aligned}
& 50 \% \text { sulfuric }{ }^{3} \\
& \text { Acid, pH }<2 \\
& \text { Cool, } 4^{\circ} \mathrm{C}
\end{aligned}
$$

28 days

28 days

$$
\operatorname{cool}, 4^{\circ} \mathrm{C}
$$

47 days $^{6}$

Add $3 \mathrm{ml} \mathrm{10 \%}$ sodium thiosulfate per gallon Cool, $4^{\circ} \mathrm{C}$

47 days $^{6}$

4 drops conc. hydrochloric acid, $\mathrm{CoO} 1,4^{\circ} \mathrm{C}$

$\mathrm{CoOl}, 4^{\circ} \mathrm{C}$
7 days

14 days

days 
TABLE 1 (continued)

RECOMMENDED SAMPLE CONTAINERS, SAMPIE PRESERVATION, AND SAMPLE HOLDING TTMES

Parameter

Container

\section{Iiquid - Ior to Yodiun Concentration Samples (Cantinued}

\section{Residual Chlorine \\ Present \\ Organic Compounds - Specified and Pesticides (Non- Priority Pollutants Such as Herbicides) \\ Organic Halides - Total (TOX)}

pH

Phenols

Phosphate-ortho

Phosphorus, Total

Solids, Settleable 240-ml vials with

Teflon lined septum caps

1-gal. glass (amber) or

2 1/2-gal. glass (amber)

with Teflon lined closures

250-ml amber glass with Teflon lined septum

closure

In-situ, breaker or bucket

1-1iter amber glass with Teflon lined closure

500-ml or 1-liter polyethylene with Polyethylene or polyethylene lined closure

500-ml or 1-1iter polyethylene with polyethylene or polyethylene lined closure

1/2-gal. polyethylene with polyethylene closure
Footnote 7

14 days

Footnote 8

47 days $^{8}$

Cool, $4^{\circ} \mathrm{C}$

ASAP - NS

None

Analyze Immediately

508 Sulfuric Acid, $\mathrm{pH}<2$ $\mathrm{CoOl}, 4^{\circ} \mathrm{C}$

Filter-on-site Cool, $4^{\circ} \mathrm{C}$

28 days

48 hrs.

Filter-on-site 50\% Sulfuric

Acid, $\mathrm{pH}<2$

Cool, $4^{\circ} \mathrm{C}$

Cool, $4^{\circ} \mathrm{C}$
28 days

48 hrs. 
TABLE 1 (continued)

RECOMMENDED SAMPLE CONTAINERS, SAMPLE PRESERVATION, AND SAMPLE HOLDING TIMES

Parameter

Container

Preservative

Holding

Time

\section{Iiquid - Iow to Mediun Canantration Samples (Cantinued)}

\section{Solids (Total and Suspended, etc.)}

sulfates

Sulfides

Temperature

Turbidity 500-ml or 1-1iter poly-2 ethylene with polyethylene or polyethylene lined closure

500-ml or 1-1iter poly-2 ethylene with polyethyllene or polyethylene

lined closure

500-ml of 1-1iter poly-3 ethylene with polyethy-

lene or polyethylene

lined closure

In-situ, beaker or bucket

500-ml or 1-1iter poly-2 ethylene with polyethyllene or polyethylene

lined closure
Cool, $4^{\circ} \mathrm{C}$

7 days

Cool, $4^{\circ} \mathrm{C}$

28 days

2 ml zinc Acetate ${ }^{2}$ conc. Sodium

Hydroxide to $\mathrm{pH}>9$ Cool, $4^{\circ} \mathrm{C}$

None

Determine on site

Cool, $4^{\circ} \mathrm{C}$

48 hrs. 
TABLE 1 (continued)

RECOMMENDED SAMPLE CONTAINERS, SAMPLE PRESERVATION, AND SAMPLE HOLDING TTMES

Parameter

Container

Preservative

Holding

Time

\section{Soil. Sediment or sludge samples - Iow to Modium Ooncentrations}

E. P. Toxicity

\author{
Metals \\ Nutrients, Including: \\ Nitrogen, Phos- \\ Phorus, Chemical \\ oxygen Demand \\ Organics - \\ Extractable \\ Organics - \\ Purgeable (VOA) \\ Other Inorganic \\ compounds - \\ Including cyanide
}

\author{
8-oz. widemouth glass \\ with Teflon Lined \\ closure
}

8-oz. widemouth glass

with Teflon Lined

clósures

500-ml polyethylene with polyethylene closure or

$8 \mathrm{oz}$. widemouth glass

with Teflon lined closures

8-oz. widemouth glass

with Teflon liner

4-oz. (120 ml) widemouth

glass with Teflon liner

500-ml polyethylene

with polyethylene

closure or $8-02$. wide-

mouth glass with Teflon

lined closure

$$
\text { cool, } 4^{\circ} \mathrm{C}
$$

ASAP - NS

Cool, $4^{\circ} \mathrm{C}$

6 months

$\mathrm{cool}, 4^{\circ} \mathrm{C}$

ASAP

$\mathrm{CoOl}, 4^{\circ} \mathrm{C}$

ASAP

Cool, $4^{\circ} \mathrm{C}$

ASAP

cool, $4^{\circ} \mathrm{C}$

ASAP 


\section{Footnotes:}

1. With the exception of onissions and typographical errors, the table is a direct quote from Appendix A of the ESBSOP and QA Manual.

2. Use indicated container for single parameter request, 1/2-gallon polyethylene container for multiple parameter requests except those including BOD, or 1-gallon polyethylene container for multiple parameter request which include BOD.

3. Must be preserved in the field at time of collection.

4. Use ascorbic acid only if the sample contains residual chlorine. Test a drop of sample with potassium iodide-starch test paper; a blue color indicates need for treatment. Add ascorbic acid, a few chrystals at a time, until a drop of sample produces no color on the indicator paper. Then add an additional $0.6 \mathrm{~g}$ of ascorbic acid for each liter of sample volume.

5. May include nitrogen series (ammia, total Kjeldahl nitrogen, nitrate-nitrite), total phosphorus, chemical oxygen demand and tota! nrganic carbon.

6. Samples must be extracted within seven days and extract must be analyzed within 40 days.

7. Collect the sample in a 4-OZ. Soil VOA container which has been pre-preserved with four drops of 10 percent sodium thiosulfate solution. Gently mix the sample and transfer to a $40 \mathrm{ml}$ VOA vial that has been prepreserved with four drops concentrated $\mathrm{HCl}$, cool to $4^{\circ} \mathrm{C}$.

8. See Organic compounds - Extractable. The receiving analytical laboratory should be consulted for any special organic compound analyses in order to check on special preservation requirements and/or extra sample volume. 
Yethod Number: ESP 307-1

Revision Number: 0

Date: August 29, 1988

Page: 1 of 5

MARTIN MARIETTA ENERGY SYSTEMS, INC.

ENVIRONMENTAL SURVEILIANCE PROCEDURES

SUBJECT: FIELD MEASUREMENTS PROCEDURES - TEMPERATURE

I. Scope and Application

This procedure is applicable to ground, surface, and saline waters as well as domestic and industrial waste.

II. References

A. A Compendium of superfund Field operations Methods, EPA/540/P-87/001, U.S. Environmental Protection Agency, Washington, D.C., 1987.

B. Data Quality Objectives for Remedial Activities Development Process, EPA/540/G-87/003, U.S. Environmental Protection Agency, Washington, D.C., 1987.

c. Engineerina support Branch standard operating Procedures and ouality Assurance Manual, U.S. Environmental Protection Agency, Region IV, Athens, Georgia, April 1, 1986.

D. Standard Methods for the Examination of Wastewater, 16th Edition, Method 212, 1985.

E. The Environmental survey Manual, Appendix E "Field Protocols and Guidance," Us Department of Energy, August 1987.

III. Summary of Method

Temperature measurements may be made with any calibrated high guality mercury-filled thermometer or thermistor with analog or digital read-out device. 
Method Number: ESP 307-1

Revision Number: 0

Date: August 29, 1988

Page: 2 of 5

MARTIN MARIETTA ENERGY SYSTEMS, INC.

ENVIRONMENTAL SURVEILIANCE PROCEDURES

IV. comments

For field operations using a glass thermometer, the thermometer will be transported in a protective case to prevent breakage. Thermometers or thermistors used with this procedure require calibration with a certified NBS thermometer.

v. Required Equipment and Apparatus

A. Thermometer - certified by NBS with its certificate and correction chart, for initial calibration and checks only.

B. Thermometer and Thermistor - the scale should be in Celsius and marked as appropriate to meet data quality objectives.

c. Measurement Device Carrying Case.

VI. Safety

It is Energy Systems' policy to maintain an effective program for control of employee exposure to chemical, radiological, and physical stress which is consistent with the requirements of Martin Marietta corporation, DOE, and OSHA established standards and requirements. All field personnel will be provided with appropriate protective clothing and safety equipment.

Refer to a site specific health and safety plan for detailed health and safety procedures. This plan should be reviewed prior to beginning work. 
Method Number: ESP 307-1

Revision Number: 0

Date: August 29,1988

Page: 3 of 5

MARTIN MARIETTA ENERGY SYSTEMS, INC.

ENVIRONMENTAL SURVEILIANCE PROCEDURES

VII. Procedure

A. Use only mercury-filled thermometer or thermistor that is in calibration.

B. Inspect thermometer before each field trip to ensure that there are neither cracks in the glass, nor air spaces or bubbles in the mercury.

c. Allow thermometer or thermistor enough time to equilibrate to outside temperature when removed from a field vehicle.

D. Insert thermometer or thermistor in-situ when possible, or in a grab sample. Swirl the thermometer or thermistor in the sample, and take the temperature reading when the mercury column or digital readout stabilizes: record temperature in field logbook to the nearest $0.5^{\circ} \mathrm{C}$ or $1.0^{\circ} \mathrm{C}$, depending on need.

VIII. contamination control

sampling tools, instruments and equipment will be protected from sources of contamination prior to use and decontaminated after use as specified in ESP-900. Iiquids and materials from decontamination operations will be handled in accordance with ESP-1000. Sample containers will also be protected from sources of contamination. sampling personnel shall wear chem.cil resistant gloves when handiing any samples. Gloves will be decontaminated or disposed between samples.

IX. OACOC

In addition to adhering to the specific requirements of this sampling protocol and any supplementary site specific procedures, the minimum QA/QC requirements for this sampling activity are the following. 
Method Number: ESP 307-1

Revision Number: 0

Date: August 29, 1988

Page: 4 of 5

MARTIN MARIETTA ENERGY SYSTEMS, INC.

ENVIRONMENTAI SURVEILIANCE PROCEDURES

\section{A. Control of Deviations}

When feasible, any departure from specified requirements will be justified and authorized prior to deviating from the requirements. Deviations shall be sufficiently documented to allow repetition of the activity as actually performed.

B. Calibration

Each temperature measurement device will be initially calibrated at three temperatures covering the range of the device against a National Bureau of standards (NBS) certified thermometer, and then cross-checked against a calibrated NBS certified thermometer at least semiannually.

c. oc samples

The number and types of $Q C$ measurements and samples including duplicate measurements and samples, field blanks, equipment blanks and trip blanks will be collected or prepared as specified in the governing plans and procedures.

D. Verification

Verification activities are required of the above practices including surveillance and periodic record audits. These activities will be documented and become part of the completed project records.

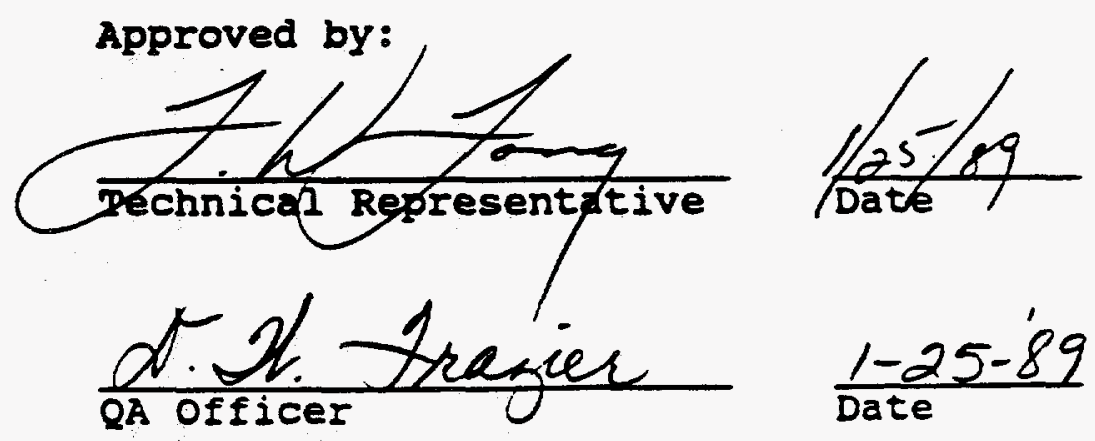


Method Number: ESP 307-1

Revision Number: 0

Date: August 29, 1988

Page: 5 of 5

MARTIN MARIETTA ENERGY SYSTEMS, INC.

ENVIRONMENTAL SURVEILIANCE PROCEDURES

\section{ATractirtant 1}

SUBJECT: FIELD MEASUREMENTS PROCEDURES - TEMPERATURE

Field Checklist

Thermometer or Thermistor

Logbook

Black Indelible Pen

Safety Glasses or Monogoggles

Gloves

Safety shoes

Manufacturer's Calibration and Instruction Manual

Sampling and Analysis Plan

Health and Safety Plan

Decontamination Equipment*

See section ESP-900 for decontamination procedures. 
Yethod Number: ESP $307-2$

Revision Number: 0

Date: August 29,1988

Page: 1 of 6

\begin{abstract}
MARTIN MARIETTA ENERGY SYSTEMS, INC.
\end{abstract}
ENVIRONIENTAL SURVEILIANCE PROCEDURES

SUBJECT: FIELD MEASUREMENTS PROCEDURES - $\mathrm{pH}$ (Hydrogen ION Concentration)

I. Scope and Application

This procedure is applicable to ground, surface, and saline waters, as well as domestic and industrial wastes.

II. References

A. A Compendium of Superfund Field operations Methods, EPA/540/P-87/001, U.S. Environmental Protection Agency, Washington, D.C., 1987.

B. Data ouality objectives for Remedial ActivitiesDevelopment Process, EPA/540/G-87/003, U.S. Environmental Protection Agency, Washington, D.C., 1987.

C. Engineering and support Branch standard operating Procedures and ouality Assurance Yanual, US-Environmental Protection Agency, Region IV, Athens, Georgia, April 1, 1986.

D. Standard Yethods for the Examination of Wastewater, 16th Edition, Method 423, 1985.

E. The Environmental Survey Manual, DOE/EH-0053, Appendix E. Field Sampling Protocols and Guidance, U.S. Department of Energy, August 1987.

III. Sum dary of Method

The pH of a sample is determined electrometrically using either a glass electrode in combination with a reference potential, or a combination electrode and a $\mathrm{pH}$ meter.

IV. comments

Coatings of oily material or particulate matter can impair electrode response. Remove these coatings by gentle wiping with a clean tissue followed by a distilled 
Method Number: ESP $307-2$

Revision Number: 0

Date: August 29, 1988

Page: 2 of 6

\section{MARTIN MARIETTA ENERGY SYSTEMS, INC.}

ENVIRONMENTAL SURVEILIANCE PROCEDURES

water rinse. Temperature effects on the electrometric measurement of $\mathrm{pH}$ are controlled by using instruments having temperature compensation or by calibrating the electrode meter system at the temperature of the samples.

Poorly buffered solutions with low specific conductance values (less than 200 umhos) may cause fluctuations in the $\mathrm{pH}$ readings. Equilibrate electrode by immersing in sample before taking $\mathrm{pH}$ measurements.

Note: This procedure is complete when the manufacturers' calibration and maintenance instructions are attached.

V. Required Equipment and Apparatus

1. DH Meter - Consisting of potentiometer, a glass electrode and a reference electrode (or combination electrode) and temperature compensating device.

2. Reagents - Secondary standard buffer solutions (pH 4, pH 7 , and $\mathrm{pH}$ 10) purchased from commercial vendors shall be used.

3. Beakers - Preferably polyethylene or Teflon. (as necessary)

VI. Safety

It is Energy Systems' policy to maintain an effective program for control of employee exposure to chemical. radiological, and physical stress which is consister sith the requiremenis of Martin Marietta Corporation, DOr, and OSHA established standards and requirements. All field personnel will be provided with appropriate protective clothing and safety equipment. 
Method Number: ESP 307-2

Revision Number: 0

Date: August 29,1988

Page: 3 of 6

\section{MARTIN MARIETTA ENERGY SYSTEMS, INC.}

ENVIRONMENTAL SURVEILIANCE PROCEDURES

Refer to a site specific health and safety plan for detailed health and safety procedures. This plan should be reviewed prior to beginning work.

VII. Procedure

A. Prior to field activity check meter for mechanical and electrical failures, weak batteries, and cracked or fouled electrodes. Check pH recorders for recording and time scale accuracy.

B. Following instructions provided with each type of meter, test the meter against standard buffer solutions before using. Thereafter, the meter can be checked periodically against two buffers that bracket the expected value of the sample. Use a fresh aliquot of buffer solution for each measurement. Multi-range pH paper may be used to determine expected value.

c. For $\mathrm{pH}$ meter without automatic temperature compensation, bring the sample and buffer to same temperature, if possible. If the sample temperature differs more than $2^{\circ} \mathrm{C}$ from the buffer solutions. adjust for temperature difference.

D. Thoroughly rinse the electrode with distilled water and remove excess water between immersion in each buffer solution and sample.

E. Immerse the electrode in-situ when possible. If it is necessary to measure $\mathrm{pH}$ on a portion of the sample swirl the electrode at a constant rate until the meter reading reaches equilibrium. The rate of stirring used should minimize the air transfer rate at the air-water interface of the sample.

F. Note and record sample $\mathrm{pH}$ to the nearest $0.1 \mathrm{pH}$ unit; repeat measurement on successive volumes of sample or in-situ until values differ by no less than $0.1 \mathrm{pH}$ unit. Two or three volumes are usually sufficient. 
Method Number: ESP 307-2

Revision Number: 0

Date: August 29,1988

Page: 4 of 6

MARTIN MARIETTA ENERGY SYSTEMS, INC.

ENVIRONMENTAL SURVEIILANCE PROCEDURES

G. For samples of high ionic strength, condition electrodes after cleaning by dipping them into sample for one minute, immerse in fresh portion of the same sample, and read pH.

H. For dilute, poorly buffered solutions, equilibrate electrodes by immersing in three or four successive portions of sample. Take a fresh sample to measure pH.

I. Turn off meter at last reading.

J. Rinse electrodes thoroughly with distilled water and store in appropriate storage solution as described in operating instructions for the specific meter or electrode.

K. Record data in notebook, per ESP-500, and complete Chain-of-Custody forms.

VIII. Contamination control

Sampling tools, instruments and equipment will be protected from sources of contamination prior to use and decontaminated after use as specified in ESP-900. Liquids and materials from decontamination operations will be handled in accordance with ESP-1000. Sample containers will also be protected from sources of contamination. Sampling personnel shall wear chemical resistant gloves when handiing any samples. Glo'es will be decontaminated or disposed between samples.

IX. $\mathrm{QA} \angle O C$

The pH meter will be calibrated in accordance with manufacturer's operating instructions, prior to daily use. Thereafter, the meter will be checked periodically against two buffers that bracket the expected value of the sample.

In addition to adhering to the specific requirements of this sampling protocol and any supplementary site specific procedures, the minimum $Q A / Q C$ requirements for this sampling activity are the following. 
Method Number: ESP $307-2$

Revision Number: 0

Date: August 29,1988

Page: 5 of 6

\section{MARTIN MARIETTA ENERGY SYSTEMS, INC.}

ENVIRONRENTAI SURVEIIIANCE PROCEDURES

\section{A. Control of Deviations}

When feasible, any departure from specified requirements will be justified and authorized prior to deviating from the requirements. Deviations shall be sufficiently documented to allow repetition of the activity as actually performed.

\section{B. OC samples}

The number and types of $Q C$ measurements and samples including duplicate measurements and samples, field blanks, equipment blanks and trip blanks will be collected or prepared as specified in the governing plans and procedures.

c. Verification

Verification activities are required of the above practices including surveillance and periodic record audits. These activities will be documented and become part of the completed project records.

Approved by:

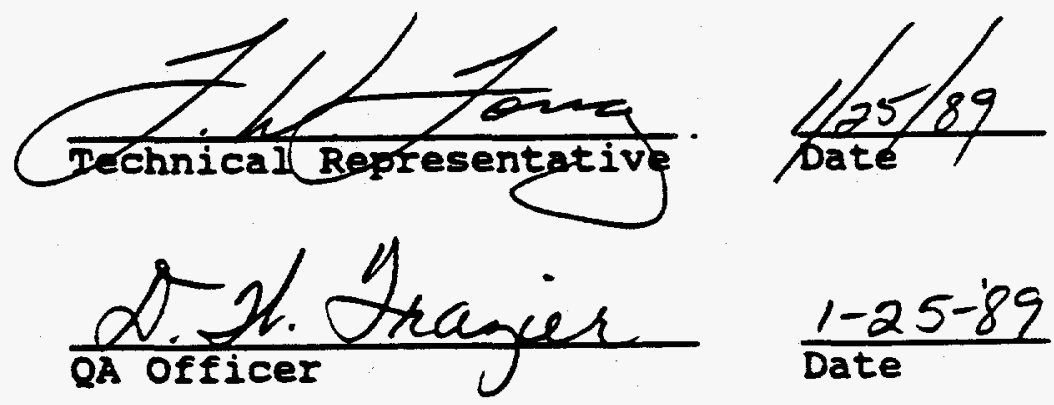


Method Number: ESP 307-2

Revision Number: 0

Date: August 29, 1988

Page: 6 of 6

MARTIN MARIETTA ENERGY SYSTEMS, INC.

ENVIRONEENTAL SURVEILIANCE PROCEDURES

\section{ATTAGEYTRNT I}

SUBJECT: FIELD MEASUREMENTS PROCEDURES - pH (Hydrogen IOn Concentration)

Field Checklist

$\mathrm{pH}$ Meter and electrodes

Buffer Solutions

Logbook

Safety Glasses or Monogoggles

Beakers

Disposable Gloves

Safety Shoes

Nulti-range pH Paper

Black Indelible Pen

Sampling and Analysis Plan

Health and Safety Plan

Decontamination Equipment*

Lab wipes

Manufacturer's Calibration and Maintenance Instructions Appropriate Containers for Waste

* See section ESP-900 for decontamination procedures and equipment requirements. 
MARTIN MARIETTA ENERGY SYSTEMS, INC. ENVIRONMENTAL SURVEILLANCE PROCEDURES QUALITY CONTROL PROGRAY
PROCEDURE NUMBER ESP-307-8 IAD DATE OF APPROVAL: Apri1-22-1993 PAGE: 1 OF 8 SUPERSEDES ISSUE: DATE :

TITHE: FINTD MEASUREMETSS PROCEDURES:

\section{SPECIFIC CONDUCTANCE}

\subsection{SCOPE}

1.1 This procedure is issued as an Immediate Action Directive to answer an immediate need which has surfaced in the environmental field surveillance activities.

1.2 This procedure is applicable to ground and surface waters as well as domestic and industrial waste.

$-\ldots 1.3 \ldots$ This procedure is applicable. to Energy. Systems (ES) and Es subcontractors conducting environmental compliance activities.

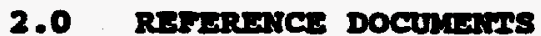

2.1 A Compendium of Superfund Field Operations Methods, EPA/540/P-87/001, U.S. Environmental Protection Agency, Washington, D.C., 1987.

2.2 Data Quality Objectives for Remedial Activities Developmont Process, EPA/540/G-87/003, U.S. Environmental Protection Agency, Washington, D.C., 1987. : 2.3nerEnvironmental Compliance Branch Standard: Operating Procedures and Quality Assurance Manual, U.S. Environmental Protection Agency, Region IV, Athens, GA, 1991.

2.4 Standard Mothods for the Examination of Wastewater, 18th Edition, Method 2510, 1989.

2.5 The Envirommental Survey Manual, Appendix E "Field Protocols and Guidance," U.S. Department of Energy, August 1987.

\subsection{RESPONSIBIIITIES}

3.1 Project/Progran Manager

3.1.1 includes this method into the project/program sample and analysis plan (SAP) for meeting the minimum compliance requirements as applicable;

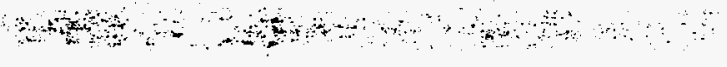


Martin Marietta Energy Systems, Inc. Environmental Surveiliance Procedures Quality Control Program
Procedure Number: ESP-307-8

Revision Number: IAD

Page: 2 of 8 Date $3 / 93$

3.1 .2 directs the sample team leader in implementation of the requirements in this Procedure:

3.1.3 ensures, verifies, and documents applicable training as required for this procedure;

3.1 .4 verifies that the Quality control (QC) requirements of this document are properly satisfied;

3.1.5 ensures the flowdown of this document into the project/program SAP; and

3.1.6 examines the flow process within the specific project/program for compliance to the requirements of this procedure.

\subsection{Sampling Tean Leader}

3.2.1 directs the sampling team activities to achieve the correct application of this procedure;

3.2.2 verifies that sampling events of the gpeciflc project/program, where applicable, meet the requirements presented in this document; and

3.2.3 performs activity related self assessments of project/program adherence to this document.

\subsection{Sampling Tean Members}

3.3.1 becomes familiar with and knowledgeable of the requirements of this procedure prior to start of sampling activities;

3.3.2 implements the requirements of this procedure; and

3.3.3 strives for elimination of deviations during from this procedure.

\subsection{TERMINOLOGY}

Does not apply to this method.

5.0 SUMMARY OF MEYHOD

5.1 Specific conductance of a sample is measured using a self-contained conductivity meter (Wheatstone bridge type or equivalent).

5.2 Conductivity measurements are corrected for sample temperature differences to allow standard reporting at 25 degrees Celsius (C). 
Martin Marietta Energy Systems, Inc. Environmental Surveiliance Procedurea Quality Control Program
Procedure Number: ESP-307-8

Revision Number: IAD

Page: 3 of 8 Date $3 / 93$

\subsection{SIGTIFICANCE AND USE}

6.1 This procedure becomes effective upon approval.

6.2 This procedure for measuring specific conductance meets the minimum requirements for environmental compliance activities.

6.3 Any specific needs beyond the scope of this procedure must be covered in project and/or program specific SAP planned activities.

\subsection{INHYRFERMTCES}

7.1 Erratic measurements will result if the instrument electrodes become corroded.

7.2 The conductance cell muat be clean of oil or other materials to prevent exroneous readinge.

$7.3^{3}$ Conduct IVIty reportied at 25 degrees $c$. Then the teaperature of the sample varies from the 25 degrees $c$ standard; and an instrument with built-in temperature compensation is not bêling utilized, a temperature correction factor must be used to report the conductance in umos/cm at 25 degrees C (Refer to

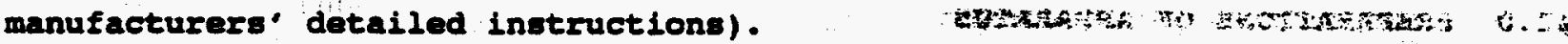
8.0 Appraros

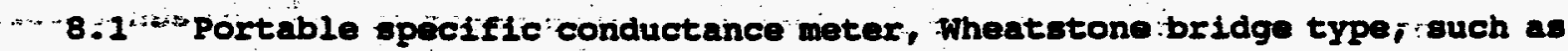
the YSI 3403 or equivalent.

8.2 Calibrated thermometer or thermistor for temperature measurement.

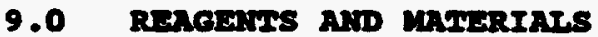

9.1 Conductivity standards of potaseium chloride solution (xCl) with known values to produce low, middle, and high scale values.

9.2 Distilled or deionized water (referenced as distilled water in this procedure) of sufficient purity as to have a specific conductance at or below the lower limit of the lowest range of the instrument in use.

10.0 BARRDS

10.1 : It is Energy Systems" pollcy to maintain an effective program for control of employee exposure to chemical, radiological, and physical stress which

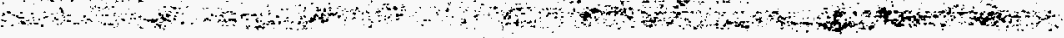


Martin Marietta Energy Systems, Inc. Environmental Surveillance procedures Quality control Program
Procedure Number: ESP-307-8

Revision Number: IAD

Page: 4 of 8 Date $3 / 93$

is consistent with the requirements of Martin Marietta Coxporation, DOE, and the OSHA established standards and requirements.

10.2 All field peraonnel will be provided with appropriate protective clothing and safety equipment.

10.3 Field personnel are required to wear personal protective equipment while performing this procedure. Refer to the project Health and safety Plan and site specific requirements.

10.4 Refer to a site specific health and safety plan for detailed health and safety procedures.

10.5 Liquids and materials from decontamination operations will be handled in accordance with EsP-1000.

10.6 Used gloves will be decontaminated or disposed of between sample locations to avoid cross contamination.

\subsection{SAMPLING, TEST SPECIMENS, AND IEST UnITS}

Does not apply to this method.

\subsection{PREPARATIONS OF APPARATUS}

12.1 Sampling tools and equipment will be protected from sources of contamination prior to sampling, and decontaminated prior to and between sampling as specified in ESP-900.

12.2 Sample containers will also be protected from sources of contamination.

12.3 As A minimum standardization of tegt equipment shall be performed and documented prior to use each day.

\subsection{CAIIBRATION AND STANDARDIZATION}

13.1 Calibrations, of the specific conductance meter, are conducted by designated instrument certification group using certified standards at the time interval specified in section 19.1 .2 .4 or when an unsatisfactory daily standardization is obtained (refer to the manufacturers instructions for the calibration of the epecific instrument in use). 
Martin Marietta Energy Systems, Inc. Environmental Surveillance Procedures Quality Control Program
Procedure Number: ESP-307-8

Revision Number: IAD

Page: 5 of 8 Date $3 / 93$

13.2 Certified standard solutions are to be used in the instrument calibration procedure.

13.3 Calibration logs will be documented and maintained by the certification group.

13.4 A copy of the certification sheet for the instrument of use will be kept on file as an operational quality Assurance record.

\section{0 coniorgrovine}

Does not apply to this method.

15.0 PROCHDUR

15.1 Check instrument batteries to ensure a full charge condition.

15.3 switch instrument to on and allow the conductance measuring instrument to warm up. coneult manufactarers inetructions.

15.2 Inspect instrument and perform an initial standardization per manufacturers inetructione before each dally fleld trip to ensure that the instrument is in proper working order (Reference section 19.1.2).

15.4 Refer to the ingtrument inetruetions for temperature compensetion requirements?

- 15.5 pon clean chenical residant gloves as appropriate for protect lon and comtanination eliminatibn

15.6 Perform field measurement for temperature as required, (refer to ESP 307-1):

15.7 Rinse probe thoroughly with distilled water and remove excess water from probe before innersion of probe in sample.

15.8 Immerse the probe in the sample and swirl until equilibrium is reached.

Note: Duplicate fleld analysis should not vary more than plus or minus 10 percent of a two reading average.

15.9" Record" readings in fleld log book per Esp 500, "Manual Chain of Custody" .

and 
Martin Marietta Energy Systems, Inc. Environmental Surveillance Procedures Quality Control Program
Procedure Number: ESP-307-8

Revision Number: IAD

Page: 6 of 8 Date $3 / 93$

15.10 Withdraw probe from sample and rinse with distilled water.

15.11 Store probe in appropriate solution, when finished, as perscribed in the operating instructions for the specific meter or electrode.

16.0 CALCULATION OR INTERPRETATION OF RESUTIS

16.1 When a conversion for temperature is required, refer to manufacturers' detailed instructions.

16.2 Conversion to umhos/cm at 25 degrees $C$ is performed.

17.0 REPORT

17.1 Report all conductance measurements in unhos/cm at 25 degrees $\mathrm{C}$.

17.2 Records are managed according to those guidelines found in ESP 500. 18.0 PRECISION AND BIAS.

18.1 Duplicate samples must agree within plus or minus 10 percent of the two reading average.

18.1 When the 10 percent criteria cannot be met refer to manufacturera* instructions.

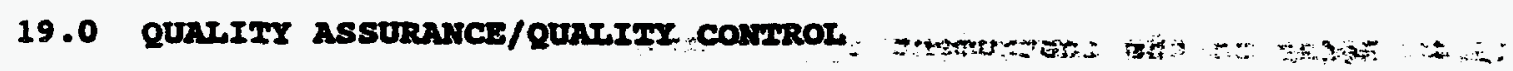

19.1 In addition to adhering to the specific requirements of this sampling protocol and any supplementary oite opecific procedures the minimum $Q A / Q C$ requirements for this sampling activity are the following:

19.1 .1 Control of Doviations

19.1.1.1 When feasible, any departure from specified requirements will be justified and authorized prior to deviating from the requirements.

19.1.1.2 All deviations will require appropriate management sign-off and be sufficiently documented to allow repetition of the activity as actually performed.

\subsubsection{QC Requirements}

19.1.2.1 Each conductance measurement instrument will be standardized before each daily field trip using certified standards and following the manufacturers' detailed instructions. 
Martin Marietta Energy Systems, Inc. Environmental Surveiliance Procedures quality Control Program
Procedure Number: ESP-307-8

Revision Number: IAD

Page: 7 of 8 Date $3 / 93$

Note: A certified standard is a purchased standard that has been calibrated againgt a standard reference material (SRY) available from the National Institute of Standards and Technology (NIST), or a standard prepared by field or laboratory personnel that has documented calibration againgt a NIST standard.

19.1.2.2 Each instrument will be field checked during and at the conclusion of the day's activities using the standard solution referred to in Section 9.0 that best covers the range of field measurements encountered.

19.1.2.3 Instrument specific acceptance criteria for these standards will be defined, and results obtained outside these limits will require recalibration of the instrument.

19.1.2.4 Each specific conductance instrument will be calibrated and maintenance performed routinely at ix month interval as

19.1.2.5 Type of $Q / C$ samples includes
duplicate measurements; and
- known control (standard) solutions
$19.1 .3^{3}$ verification

19.1.3.1 Verification activitieg are required of the above practices including periodic survelliance and record audits.

19.1.3.2 Thene activities will be documented and becom part of the project/program records.

\subsection{AMTIETES AMD APPMTICES}

20.1. Appendix A - Suggested Field Checklist

Note: Non-mandatory example.
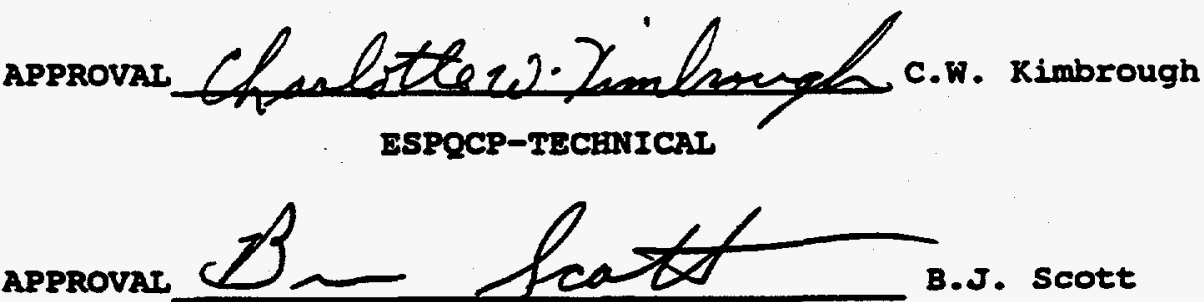

EsPQCP Committee Chairperson

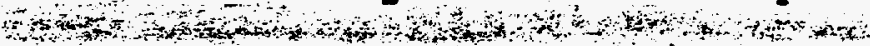


Martin Marietta Energy Systems, Inc. Environmental Surveiliance Procedures Quality Control Program
Procedure Number: ESP-307-8

Revision Number: IAD

Page: 8 of 8 Date $3 / 93$

\section{APPEDTX A}

\subsection{Field Checklist}

$$
=2
$$

5

i.

Conductance Measuring Device

Logbook

Black, Indelible Pen

Safety Glasees or Kono-goggles

Gloves.

safety shoes

DLetilled Water

Calibration standards

Manufacturer's Calibration and Instruction Manual

Sampling and Analyaia Plan

$$
\text { ite }
$$

Health and safety Plan

Decontamination Equipment

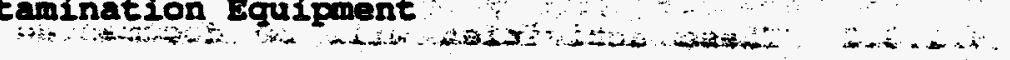
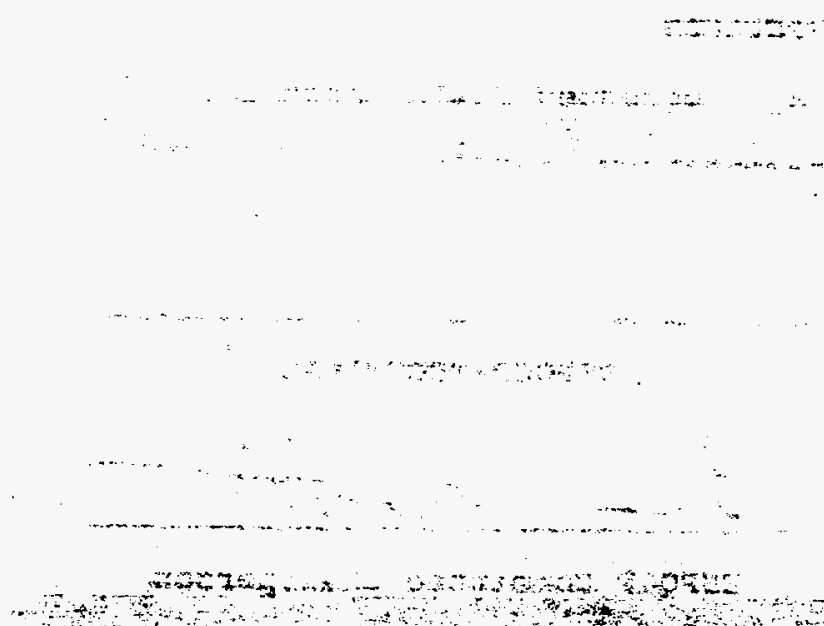
ENVIRONMENTAL SURVEILLANCE QUALITY CONTROL PROGRAM

ESP-801

THE LOCATION OF PROCEDURE ESP-900, REV. 0 HAS BEEN CHANGED TO ESP-801.

ESP-801 WILL BE ISSUED IN THE NEAR FUTURE TO REPLACE ESP-900, REV. 0.

SUBJECT: CLEANING AND DECONTAMINATING SAMPLE CONTAINERS AND SAMPLING DEVICES

ISSUE DATE: $8 / 27 / 88$ 
Method No.: ESP-900

Revision No.: 0

Date: August 27, 1988

Page 1 of 20

MARTIN MARIETTA ENERGY SYSTEMS, INC.

ENVIRONMENTAL SURVEILLANCE PROCEDURES

SUBJECT: CLEANING AND DECONTAMINATING SAMPLE CONTAINERS AND SAMPLING DEVICES

I. Scope and Application:

This procedure establishes methodologies for cleaning and decontaminating sample cor.tainers and sampling devices.

II. References:

A. Engineer:ng Support Branch Standard Operating Procedures and Qual ity Assurance Manual, U.S. Environmental Protection Agency, Athens, GA, 1986.

B. Federal Reoister, Volume 44, 40 CFR Part 136. "Guidelines Establishing Test Procedures for the Analysis of Pollutants Under the Clean Water Act."

C. Test Methods for Evaluating Solid Waste, SW-846, 2nd Edition, U.S. Environmental Protection Agency, Washington, D.C., 1982.

III. Summary of Method:

Sampling containers used by field sampling teams may be obtained precleaned from commercial supplier, supplied by the supporting analytical laboratory, or prepared by the field team. Sampling devices must be cleaned prior to being used in the field to prevent potential contamination of a sample. Sampling devices must be cleaned and decontaminated between samples to prevent cross-contamination and must be decontaminated at the close of the sampling event prior to being taken off-site.

An acceptable alternative to cleaning -and decontaminating sampiri. devices is the use of items cleaned or sterilized by the manufacturer that are discarded after use. Care must be exercised to ensure such previously cleaned or sterilized items do not retain residues of chemical or radioactive sterilizing agents that might interfere with analytical techniques.

IV. Comments:

The cleaning materials referred to in this procedure are defined in the following paragraphs. 
Method No.: ESP-900

Revision No.: 0

Date: August 27, 1988

Page: 2 of 20

MARTIN MARIETTA ENERGY SYSTEMS, INC.

ENVIRONMENTAL SURVEILLANCE PROCEDURES

A. Definitions

1. Sample containers include, but are not limited to, the following:

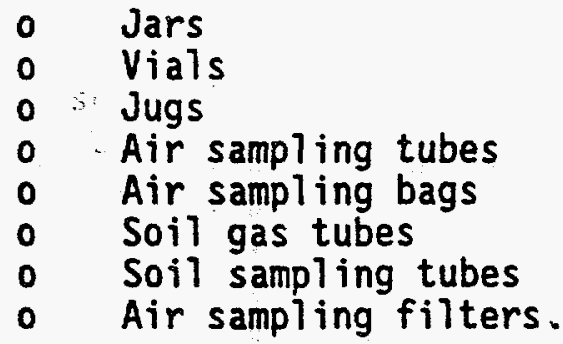

2. The 7aboratory detergent must be a standard brand of phosphatefree laboratory detergent such as Alquinox, Liquinox, or the equivalent.

3. The nitric acid solution (10 percent) is made from reagentgrade nitric acid and deionized or organic-free water.

4. The standard cleaning solvent will be pesticide-grade isopropano1. The use of any solvent other than pesticide-grade isopropanol for equipment cleaning purposes must be justified and approved by the responsible project personnel and will be documented in logbooks. The laboratory must be informed as weไl.

5. Tap water may be used from an approved municipal water treatment system. The use of an untreated potable water supply is not an acceptable substitute for tap water.

6. Deionized water is defined as tap water that has been treated by passing through a standard deionizing resin column. The deionized water should contain no heavy metals or other inorganic compounds (i.e., at or above analytical detection limits) as defined by a standard Inductively Coupled Argon Plasma Spectrophotometer (ICP) scan.

7. Organic-free water is defined as tap water that has been treated with activated carbon and deionizing units or water from a Milli-Q system (or equivalent). 
Method No.: ESP-900

Revision No.: 0

Date: August 27, 1988

Page: 3 of 20

\section{MARTIN MARIETTA ENERGY SYSTEMS, INC.}

ENVIRONMENTAL SURVEILLANCE PROCEDURES

\section{B. General}

During cleaning operations, the substitution of a higher grade water (i.e., deionized or organic-free water for tap water) is permitted and need not be noted as a variation.

The brushes used to clean equipment as outlined in the various sections of this procedure must not be of the wire-wrapped type.

The solvents, nitric acid solution, laboratory detergent, and rinse waters used to clean equipment must not be reused, except as specifically permitted.

V. Required Equipment and Apparatus:

Cleaning materials and equipment.are outlined in Attachments 1 and 2.

VI. Safety

Safety glasses or goggles, gloves, and laboratory coat or apron will be worn during cleaning operations. Solvent rinsing will be conducted under a fume hood or in the open (never in a closed room). No eating, smoking, drinking, chewing, or hand to mouth contact will be permitted during cleaning operations.

VII. Procedure:

A. Select appropriate cleaning procedure from Attachments.

B. Segregation of Used Field Equipment:

Field equipment or reusable sample containers needing cleaning must not be stored with clean equipment, -sample tubing, or sample containers. Field equipment, reusable sample containers, disposable sample containers, and sample tubing that are not used may not be replaced in storage without being recleaned if these materials are transported to a facility or study site where contamination or suspected contamination was present.

C. Storage of Cleaned Field Equipment and Sample Containers:

Previously cleaned sample containers and field equipment that are cleaned using the procedures outlined in the attachments are stored 
Method No.: ESP-900

Revision No.: 0

Date: August 27, 1988

Page: 4 of 20

MARTIN MARIETTA ENERGY SYSTEMS, INC.

ENVIRONMENTAL SURVEILLANCE PROCEDURES

\begin{abstract}
in a contaminant-free environment. Sample containers and field equipment are stored separately from all other equipment and supplies and from each other.

D. Transporting Used Sample containers off-Site:
\end{abstract}

Sample containers that contain a sample, regardless of the assumed or known level of hazard associated with that sample, must have all exterior surfaces decontaminated. For sample containers used in areas other than a controlled access area, a wipedown with disposable rags or toweling, or rinse with deionized water followed by drying with disposable rags or toweling, will suffice. Any visible dirt, water droplets, stains, or other extraneous materials must be removed. For containers used in controlled access areas, a more rigorous cleaning and/or radiation monitoring may be required. Refer to the project specific work plan for details.

\title{
VIII.Contamination Control:
}

The solvent used to implement the cleaning procedures outlined in this method will be collected and disposed of by allowing to evaporate under a fume hood or be containerized and disposed per ESP-1000. Similarly, spent acids will be collected and disposed of by ESP-1000. These procedures apply whether cleaning procedures take place in the washroom or in the field.

IX. QA/OC:

A. General

This section outlines guidelines for specific quality control procedures to monitor the effectiveness of cleaning procedures given in the attachments. Refer to the appropriate project work plans for more detail as necessary.

B. Rinse Water

The quality of the deionized and organic-free water used may be monitored by collecting samples in standard precleaned, sample containers and submitting them to the laboratory for a standard ICP scan. Organic-free water should be submitted for low level pesticide, herbicide, extractable, or purgeable compounds analyses as appropriate. 
Method No.: ESP-900

Revision No.:

0

Date: August 27, 1988

Page: 5 of 20

MARTIN MARIETTA ENERGY SYSTEMS, INC.

ENVIRONMENTAL SURVEILLANCE PROCEDURES

\section{Equipment Cleaning}

The effectiveness of the equipment cleaning procedures is monitored by submitting to the laboratory rinse water for low level analysis of the parameters of interest. An attempt should be made to select different pieces of equipment for this procedure, each time equipment is washed, so that a representative sampling (approximately 10 percent) of all equipment is obtained over the length of the project.

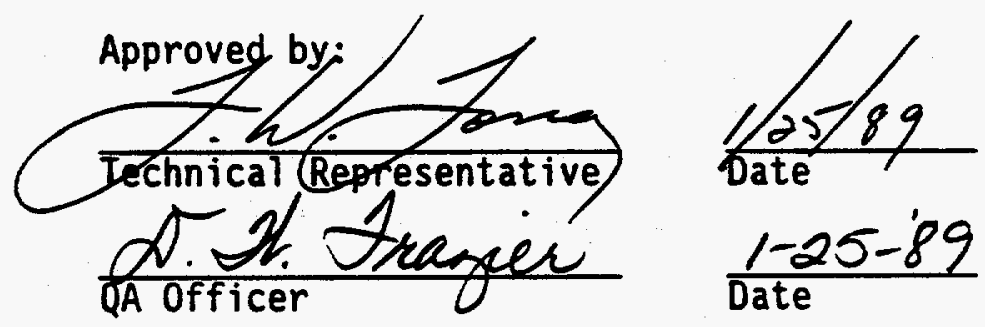


Method No.: ESP-900

Revision No.: 0

Date: August 27, 1988

Page: 6 of 20

MARTIN MARIETTA ENERGY SYSTEMS, INC.

ENVIRONMENTAL SURVEILLANCE PROCEDURES

\section{ATTACHMENT 1}

I. Preparation of Disposable Sample Containers

A. General

Disposable sample containers will be stored in their original packing containers. When packages of uncapped sample containers are opened, they will be stored to prevent contamination. Specific precleaning instructions for disposable sample containers are given in the following sections. These instructions apply to disposable sample containers whether they are purchased from an outside source or are precleaned by laboratory personnel.

B. Cleaning of Sample Containers That Are Recommended For Use in the Analysis of:

Acidity/Alkalinity

Chloride

COD (Chemical Oxygen Demand)

Color

Conductivity

Cyanide

Extractable Organics
Hardness

Mercury

Metals

Oil \& Grease Sulfide

$\mathrm{pH}$

Phenols. TOC (Total Organic Carbon)

Phosphate Turbidity
Settleable Residue/Suspended Solids

Silica

Sulfate

Sulfite

1. Wash bottles and jars, Tefion 1 iners, and caps in hot tap water and laboratory detergent.

2. Rinse three times with tap water. 
Method No.: ESP-900

Revision No.: 0

Date: August 27, 1988

Page: 7 of 20

MARTIN MARIETTA ENERGY SYSTEMS, INC.

ENVIRONMENTAL SURVEILLANCE PROCEDURES

3. Rinse with nitric acid solution. 1

4. Rinse three times with deionized water.

5. Rinse bottles, jars, and liners (not caps) with solvent. 1

6. Oven dry bottles, jars, and liners $\left(125^{\circ} \mathrm{C}\right.$. recommended) Allow to cool.

7. Place liners in caps and cap containers.

8. Store containers in contaminant-free area.

C. Cleaning of sample containers that are recommended for use in the analyses of:

COD

Nitrate-Nitrite

Purgeable (Volatile) Organics

TOC

Trihalomethanes

1. Wash containers, septa or liners, and closures in hot tap water with laboratory grade non-phosphate detergent.

2. Rinse three times with tap water.

3. Rinse three times with deionized water:

4. Oven dry containers, septa or liners, and closures.

5. Remove containers, septa, and closures from oven.

6. Place liners in closures, Teflon side down, and place on containers. - Attendant to wear gloves. and containers cannot be removed from preparation room unt il sealed.

${ }^{1}$ Some vendors of precleaned, disposable sample bottles use pesticide grade methylene chloride to solvent rinse sample containers. Also some of these vendors use $1: 1$ reagent grade nitric acid to rinse sample containers. For the purposes of cleaning sample containers as outlined in Section B of this Attachment, both of these deviations from the definitions contained in Section $A$ of this procedure are permitted. 
Method No.: ESP-900

Revision No.: 0

Date: August 27, 1988

Page: 8 of 20

MARTIN MARIETTA ENERGY SYSTEMS, INC.

ENVIRONMENTAL SURVEILLANCE PROCEDURES

D. Cleaning of sample containers that are recommended for use in the analysis of:

BOD

COD

$0 i 1$ and Grease
Extractable Organics

Phenols

TOC

1. Wash containers, closures, and teflon liners in hot tap water with laboratory grade non-phosphate detergent.

2. Rinse three times with tap water.

3. Rinse one time with $1: 1$ nitric acid.

4. Rinse three times with deionized water.

5. Air dry in contaminant-free environment.

6. Place liners in closures and place closures on containers.

II. Emergency Disposable Sample Container Cleaning

New jars may be used to collect samples in an emergency. These containers would also be acceptable on an emergency basis for the collection of water samples for extractable and pesticide organic analyses as well as metal analyses. These jars cannot be used for the collection of water samples for purgeable organic analyses.

The rubber sealing ring should not be in contact with the jar and aluminum foil should be used, if possible, between the jar and the sealing ring, Ii possible, the jar and aluminum foil should be rinsed with solvent 2 and allowed to air dry before use. Several empty bottles and lids should be submitted to the laboratory as blanks for quality control purposes.

2 In these circumstances pesticide grade solvents such as petroleum, ether, hexane, methanol or isopropyl alcohol may be used. 
Method No.: ESP-900

Revision No.: 0

Date: August 27,1988

Page: 9 of 20

MARTIN MARIETTA ENERGY SYSTEMS, INC.

ENVIRONMENTAL SURVEILLANCE PROCEDURES

\begin{abstract}
ATTACHMENT 2
I. Cleaning Procedures for Teflon or Glass Field Sampling Equipment Used for the Collection of Samples for Trace Organic Compounds and/or Metals Analyses ${ }^{3}$
\end{abstract}

1. Equipment will be washed thoroughly with laboratory detergent and hot water using a brush to remove any particulate matter or surface film.

2. The equipment will be rinsed thoroughiy with hot tap water.

3. Rinse equipment with at least a 10 percent nitric acid solution.4

4. Rinse equipment thoroughly with tap water.

5. Rinse equipment thoroughly with deionized water.

6. Rinse equipment twice with solvent and allow to air dry for at least 24 hours.

7. Wrap equipment with aluminum foil to prevent contamination during storage and/or transport to the field.

3 When this sampling equipment is used to collect samples that contain oil, grease or other hard to remove materials, it may be necessary to rinse the equipment several times with pesticide-grade acetone or hexane to remove the mattrials before proceeding with Step 1. In extreme cases, it may be necessary, to steam clean the field equipment before proceeding with Step 1. If the field equipment cannot be cleaned utilizing these procedures, it should be discarded.

4 Small and awkward equipment such as vacuum bottle inserts and well bailers may be soaked in the nitric acid solution instead of being rinsed with it. Fresh nitric acid solution should be prepared for each cleaning session. 
Method No.: ESP-900

Revision No.: 0

Date: August 27, 1988

Page: 10 of 20

MARTIN MARIETTA ENERGY SYSTEMS, INC.

ENVIRONMENTAL SURVEILLANCE PROCEDURES

8. Rinse the Teflon or :glass sampling equipment thoroughly with tap water in the field as soon as possible after use.

II. Cleaning Procedures for Stainless Steel or Metal Sampling Equipment Used for the Collection of Samples for Trace Organic Compounds and/or Metals Analyses $^{5}$

1. Wash equipment thoroughly with laboratory detergent and hot water using a brush to remove any particulate matter or surface film.

2. Rinse equipment thoroughly with hot tap water.

3. Rinse equipment thoroughly with deionized water.

4. Rinse equipment twice with solvent and allow to air dry for at least 24 hours.

5. Wrap equipment with aluminum foil to prevent contamination during storage and/or transport to the field.

6. Rinse the stainless steel or metal sampling equipment thoroughly with tap water in the field as soon as possible after use.

When this sampling equipment is used to collect samples that contain oil, grease or other hard to remove materials, it may be necessary to rinse the equipment several times with pesticide grade acetone or hexane to remove the materials before proceeding with Step 1. In extreme cases, when equipment is painted, badly rusted, or coated with materials that are difficult to remove, it may be necessary to steam clean, wire brush, or sandblast equipment before proceeding with Step 1. Any stainless steel sampling equipment that cannot be cleaned using these procedures should be discarded. 
Method No.: ESP-900

Revision No.: 0

Date: August 27, 1988

Page: 11 of 20

MARTIN MARIETTA ENERGY SYSTEMS, INC.

ENVIRONMENTAL SURVEILLANCE PROCEDURES

\section{Cleaning Procedures for Automatic Wastewater Sampling Equipment}

\section{A. General}

Automatic samples will be cleaned as follows:

1. The exterior and accessible interior (excluding the waterproof timing mechanism) portions of automatic samplers will be washed with laboratory detergent and rinsed with tap water.

2. The face of the timing case mechanism will be cleaned with a clean damp cloth.

3. All tubing (sample intake and pump tubing) will be discarded after use.

4. New precleaned, silastic pump tubing (see Section IV. A.) will be installed.

5. When utilizing the samplers for collecting samples for metals and/or organic compounds analyses, the metal distributor tubes should not be used; only glass or silastic pump tubing should be used for this purpose.

\section{B. Automatic Sampler Headers}

1. Disassemble header and using a bottle brush, wash with hot water and phosphate free laboratory detergent.

2. Rinse thoroughly with deionized water.

3. Reassemble header, let dry thoroughly and wrap with aluminum foil. 
Method No.: ESP-900

Revision No.: 0

Date: August 27, 1988

Page: 12 of 20

MARTIN MARIETTA ENERGY SYSTEMS, INC.

ENVIRONMENTAL SURVEILLANCE PROCEDURES

C. Reusable Glass Composite Sample Containers ${ }^{6}$

1. Wash containers thoroughly with hot tap water and laboratory detergent, using a bottle brush to remove particulate matter and surface film.

2. Rinse containers thoroughly with hot tap water.

3. Rinse containers with at least 10 percent nitric acid.

4. Rinse containers thoroughiy with tap water.

5. Rinse containers thoroughly with deionized water.

6. Rinse twice with solvent and allow to air dry for at least 24 hours.

7. Cap with aluminum foil or Teflon film.

8. After using, rinse with tap water in the field, seal with aluminum foil to keep the interior of the container wet, and return to the laboratory.

6 When these containers are used to collect samples that contain oil, grease or other hard to remove materials, it may be necessary to rinse the container. several times with pesticide grade acetone before proceeding with Step 1. If these materials cannot be removed with acetone, the container should be discarded. Glass reusable composite containers used to collect samples at pesticide, herbicide, or other chemical manufacturing facilities that produce toxic or noxious compounds shall be disposed of "properly" (preferably at the facility) at the conclusion of sampling activities and shall not be returned for cleaning. Also, glass composite containers used to collect in-process wastewater samples at industrial facilities shall be discarded after sampling. Any bottles that have a visible film, scale, or discoloration remaining after this cleaning procedure shall also be discarded. 
Method No.: ESP-900

Revision No.: 0

Date: August 27, 1988

Page: 13 of 20

MARTIN MARIETTA ENERGY SYSTEMS, INC.

ENVIRONMENTAL SURVEILLANCE PROCEDURES

D. Plastic Reusable Composite Sample Containers ${ }^{7}$

1. Proceed with the cleaning procedures as outlined in III $C$ but omit Step 6.

E. Sequential Sample Bottles (Automatic Sampler Base for Sequential Model

1. Rinse with 10 percent nitric acid.

2. Rinse thoroughly with tap water.

3. Wash using laboratory detergent, followed by tap and deionized water rinse.

4. Replace bottles in covered, automatic sampler base; cover with aluminum foil for storage.

5. Rinse bottles in the field as soon as possible after using tap water.

F. Sequential Sample Bottles (Automatic Sampler Base for Sequential Mode) to be Used for Collecting Samples for Oraanic Compounds Analyses

1. Proceed as outlined in Steps 1-4 in Section III E.

2. Rinse twice with solvent and allow to air dry for at least 24 hours.

3. Replace in covered, automatic sampler base; cover with aluminum foil for storage-and mark the base as follows: "Cleaned for organic analyses."

7 Plastic reusable sample containers used to collect samples from facilities that produce toxic or noxious compounds or are used to collect in-process waste stream samples at industrial facilities will be disposed of properly (preferably at the facility) at the conclusion of the sampling activities and will not be returned for cleaning. Any plastic composite sample containers that have a visible film, scale, or other discoloration remaining after this cleaning procedure will be discarded. 
Method No.: ESP-900

Revision No.: 0

Date: August 27, 1988

Page: 14 of 20

MARTIN MARIETTA ENERGY SYSTEMS, INC.

ENVIRONMENTAL SURVEILLANCE PROCEDURES

G. Bottle Siphons Used to Transfer Sample From Composite Container .

1. Use a new siphon for each sampling location.

2. Use 3/8-inch Teflon tubing for samples collected for organic compounds analyses. The tubing should be rinsed with solvent and dried in the drying oven overnight before use. The ends of the siphon should be capped with aluminum foil and/or Teflon film for storage. The siphon should be flushed with sample thoroughly before use.

3. The 3/8-inch PVC tubing utilized for samples, other than those collected for organic compounds analyses, should be thoroughly flushed with sample before use.

H. Reusable Teflon Composite Mixer Rods

1. Follow procedure outlined in Section I:Steps 1-6.

2. Wrap rod in aluminum foil for storage.

IV. Cleaning Procedures for Sample Tubing

A. Silastic Rubber Pump Tubing Used in Automatic Samplers and Other Peristaltic Pumps

New cleaned tubing must be used for each automatic sampler set-up. The silastic rubber pump tubing need not be replaced in peristaltic pumps where the sample does not contact the tubing or where the pump is being used for purging purposes (i.e., not being used to collect samples).

The silastic tubing shall be cleaned as follows:

1. Flush tubing with hot tap water and phosphate-free laboratory detergent.

2. Rinse tubing thoroughly with hot tap water.

3. Rinse tubing with deionized water.

4. Install tubing in automatic sampler or peristaltic pump. 
Method No.: ESP-900

Revision No.: 0

Date: August 27, 1988

Page: 15 of 20

MARTIN MARIETTA ENERGY SYSTEMS, INC.

ENVIRONMENTAL SURVEILLANCE PROCEDURES

5. Cap both ends of tubing with aluminum foil.

B. Teflon Sample Tuting

Use only new Teflon tubing cleaned as follows for collection of samples for organic compounds analyses:

1. Tefion tubing may be precut in convenient lengths before cleaning to simplify handling.

2. rinse outside of tubing with solvent.

3. Flush interior of tubing with solvent.

4. Dry overnight in the drying oven.

5. Wrap tubing and cap ends with aluminum foil to prevent contamination during storage.

C. Polyvinyl chloride (PVC) Sample Tubing

1. Use only new tubing.

2. The tubing will be flushed with sample immediately before use to remove any residues from the manufacturing or extruding process.

3. Polyvinyl chloride tubing will be used selectively where organic compounds are not of concern.

4. Tubing should be stored in original container and not removed from this container until needed.

D. Stainless Steel Tubing

1. Wash with laboratory detergent and hot water using a long, narrow, bottle brush.

2. Proceed with Steps 2-6 as outlined in Section II (footnote applies). 
Method No.: ESP-900

Revision No.: 0

Date: August 27, 1988

Page: 16 of 20

MARTIN MARIETTA ENERGY SYSTEMS, INC.

ENVIRONMENTAL SURVEILLANCE PROCEDURES

E. Glass Tubing

Use new glass tubing, precleaned as follows:

1. Rinse thoroughly with solvent.

2. Air dry for at least 24 hours.

3. Wrap tubing with aluminum foil to prevent contamination during storage.

4. Discard tubing after use.

V. Miscellaneous Equipment Cleaning Procedures

A. Well Sounders or Tapes Used to Measure Groundwater Levels 8

1. Wash with laboratory detergent and tap water.

2. Rinse with tap water.

3. Rinse with deionized or organic-free water, as appropriate.

4. Equipment should be wrapped to prevent contamination during storage or transit.

B. Submersible Pumps and Hoses Used to Purge Groundwater We $71 \mathrm{~s}^{8}$

Proceed as outlined in Section V.A.

C. Portable Power Augers (Such as the Little Beaver)

1. The engine and power head should be cleaned with a power washer, steam jenny, or hand washed with a brush using detergent (does not have to be laboratory detergent but should not be a degreaser) to remove oil, grease, and hydraulic fluid from the exterior of the unit. These units should be rinsed thoroughly with tap water.

8 The same procedure applies whether this equipment is cleaned in the washroom or in the field. 
Method No.: ESP-900

Revision No.: 0

Date: August 27, 1988

Page: 17 of 20

MARTIN MARIETTA ENERGY SYSTEMS, INC.

ENVIRONMENTAL SURVEILLANCE PROCEDURES

2. All auger flights and bits should be cleaned utilizing the procedures outlined in Section II (including footnote).

D. Miscellaneous Sampling and Flow Measuring Equipment

Miscellaneous flow measuring and sampling equipment shall be washed with laboratory detergent, rinsed with hot tap water, followed by a thorough deionized water rinse, and dried before being stored. This procedure is not used for any equipment utilized for the collection of samples for trace organic compounds or metals analyses.

E. Flow Meters, Field Analytical Equipment, and Other Field Instrumentation

The exterior of sealed, watertight equipment such as flow meters should be washed with a mild detergent (for example, liquid dishwashing detergent) and rinsed with tap water before storage. The interior of such equipment may be wiped with a damp cloth if necessary.

Other field instrumentation should be wiped with a clean, damp cloth; $\mathrm{pH}$ meter probes, conductivity probes, DO meter probes, etc. should be rinsed with deionized water before storage.

The desiccant in flow meters and other equipment should be checked and replaced if necessary each time the equipment is cleaned.

\section{F. Ice Chests and Shipping Containers}

All ice chests and reusable containers will be washed with laboratory detergent (interior and exterior) and rinsed with tap water and air dried before storage. In the event that an ice chest becomes severely contaminated, in the opinion of the field investigator, with concentrated waste or other toxic material, it shall be cleaned as thoroughly as possible, rendered unusable, and disposed of properly. 
Method No.: ESP-900

Revision No.: 0

Date: August 27, 1988

Page: 18 of 20

MARTIN MARIETTA ENERGY SYSTEMS, INC.

ENVIRONMENTAL SURVEILLANCE PROCEDURES

G. Pressure Field Filtration Apparatus?

1. Proceed with steps 1 through 5 as outlined in Section I, assembling and applying pressure to the apparatus after each rinse step (water and acid) to drive rinse material through the porous glass filter holder in the bottom of the apparatus.

2. Assemble the apparatus and cap both the pressure inlet and sample discharge lines with aluminum foil to prevent contamination during storage.

H. Organic-Free Water Storage Containers

1. These containers will be used only for storing organic-free water.

2. New containers shall be prepared as outlined in Section III. C, Steps 1-5, then rinsed thoroughly with organic-free or Milli-Q water, filled with Milli-Q water and capped.

3. Used containers shall be capped with aluminum foil immediately after being used in the field.

4. The exterior of the container will be washed with laboratory detergent and rinsed with deionized water if necessary.

5. The interior of the container will be rinsed twice with solvent.

6. The interior of the container will be thoroughly rinsed with organic-free or Milli-Q water. The container will be filled with organic-free or Milli-Q water and capped with aluminum foil for storage.

9 The same procedure applies whether the pressure filtration apparatus is cleaned in the washroom or in the field. 
Method No.: ESP-900

Revision No.: 0

Date: August 27, 1988

Page: 19 of 20

MARTIN MARIETTA ENERGY SYSTEMS, INC.

ENVIRONMENTAL SURVEILLANCE PROCEDURES

\section{Field Equipment Cleaning Procedures}

\section{A. General}

Sufficient clean equipment should be transported to the field so that an entire study can be conducted without the need for field cleaning. However, this is not possible for some specialized items of field equipment (i.e., well drilling rigs, soil coring rigs, and other large pieces of field equipment). In addition, during particularly large-scale studies, it may not be practical or possible to transport to the field all of the cleaned field equipment required. The following procedures are to be utilized when equipment must be cleaned in the field.

B. Equipment Used for Environmental or Background Sample Collection Activities

For operations involving environmental or background samples, water quality sampling equipment (i.e., Kemmerers, buckets, Do dunkers, dredges, etc.) may be cleaned with ambient or deionized water between sampling locations. A brush may be used to remove deposits of material or sediment, if necessary. If deionized water is used, water samplers should be flushed with ambient water at the next sampling location before the sample is collected. It should be emphasized that these procedures cannot be used to clean equipment for the collection of samples for organic compounds or trace metals analyses.

Flow measuring equipment (i.e., weirs, staff gauges, velocity meters, and other stream gauging equipment) may be cleaned with tap water after use between measuring locations, if necessary.

C. Teflon, Stainless Steel or Metal Equipment Used to Collect Samples for Organic Compounds and Trace Metals Analyses

Note: Large soil boring or drill rigs should be cleaned as outlined in ESP-901 before boring or drilling operations.

1. Clean with tap water and laboratory detergent using a brush if necessary to remove particulate matter and surface films.

2. Rinse thoroughly with tap water. 
Method No.: ESP-900

Revision No.: 0

Date: August 27, 1988

Page: 20 of 20

MARTIN MARIETTA ENERGY SYSTEMS, INC.

ENVIRONMENTAL SURVEILLANCE PROCEDURES

3. Rinse thoroughly with deionized or organic-free water.

4. Rinse twice with solvent.

5. Rinse thoroughiy with organic-free water and allow to air dry as long as possible.

6. If organic-free water is not available, allow equipment to air dry as long as possible. Do not rinse with deionized or distilled water.

7. Wrap with aluminum foil (dull side in), if appropriate, to prevent contamination if equipment is going to be stored or transported. Large pieces of equipment (i.e., auger flights) may be wrapped in new Visqueen, or equivalent, for transport to the field. 
ENVIRONMENTAL SURVEILLANCE QUALITY CONTROL PROGRAM

ESP-802

THE LOCATION OF PROCEDURE ESP-901, REV. 0 HAS BEEN CHANGED TO ESP-802

ESP-802 WILL BE ISSUED IN THE NEAR FUTURE TO REPLACE ESP-901, REV. 0.

SUBJECT: EQUIPMENT DECONTAMINATION

ISSUE DATE: $8 / 18 / 88$ 
Method Number: ESP-901

Revision Number: 0

Date: August 18, 1988

Page: 1 of 11

MARTIN MARIETTA ENERGY SYSTEMS, INC.

ENVIRONMENTAL SURVEILLANCE PROCEDURES

\section{SUBJECT: EQUIPMENT DECONTAMINATION}

\section{Scope and Application}

This procedure describes the method for physically removing contaminants.

It applies to chemical and radioactive decontamination of equipment used in field investigations including: well drilling equipment; soil, air and water sampling equipment; and field test equipment. It does not apply to:

- chemical analysis equipment such as portable G-C,

- cleaning of sample containers or devices before sample collection and

- health and safety equipment or protective clothing.

Site contamination characteristics will require development of additional procedures and methods as needed. The objective of decontamination is to cleanse a contaminated surface and minimize the spread of contamination to other uncontaminated surfaces, minimize personnel exposures, and minimize waste volumes.

\section{Reference}

A. The Environmental Survey Manual, DOE/EH-0053, U.S. Department of Energy, Washington D.C., 1987.

B. "Termination of Operating Licenses for Nuclear Reactors," Regulator, Guide 1.86, U.S. Nuclear Regulatory Commission, 1974.

C. Engineering Support Branch Standard Operating Procedures and Quality Assurance Manual, U.S. Environmental Protection Agency, Athens, GA, 1986.

III. Summary of Method

A. Each decontamination task must be individually assessed. Table ESP901-1 provides a list of potential decontamination methods, which 
Method Number: ESP-901

Revision Number: 0

Date: August 18, 1988

Page: 2 of 11

- MARTIN MARIETTA ENERGY SYSTEMS, INC.

ENVIRONMENTAL SURVEILLANCE PROCEDURES

may be used as a project guideline. Task planners should select the method deemed most appropriate for a particular task. If results are unsatisfactory, they should then proceed step-by-step to the more severe methods as required to successfulty complete the decontamination.

The decontamination of equipment, tools, and materials will be based on the type of items being contaminated (e.g., drill rods, samplers), the type of contamination (e.g., mud, grease), the radiation levels, and the radionuclides to be removed. The prime objectives are to limit exposure of personnel and to minimize the generation of solid and liquid waste. The initial decontamination will require removal of mud and other visible contamination using scrapers, brushes, etc. (only in damp conditions). Items may then be wiped using a wet cloth or wipe if the radiation levels permit. All contaminated material. must be collected, contained, and packaged for disposal as appropriate. If smears and radiation instrument scans of the item indicate that the decontamination was successful, the item can be moved to the location where it will be decontaminated according to reference $C$.

If the item has not been successfully decontaminated using the above procedures or cannot be monitored due to its shape (such as the inside of a pipe), a decision as to further decontamination measures will be made by appropriate staff.

IV. Comments

Decontaminate equipment in designated areas only. To the extent possible, decontamination of equipment in the field should be avoided. Contamination control (e.g. use of plastic wrappings, use of strippable or decontaminable coatings) may be used for delicate instruments and materials that are not easily decontaminated (e.g. porous or oddly shaped materials or delicate surfaces). Decontamination methods selected for use will be evaluated for adherence to ALARA principles prior to use.

V. Required Equipment and Apparatus

A. Nonexpendable Equipment

Required equipment and apparatus is dependent upon the nature of the 
Method Number: ESP-901

Revision Number: 0

Date: August 18, 1988

Page: 3 of 11

MARTIN MARIETTA ENERGY SYSTEMS, INC.

ENVIRONMENTAL SURVEILLANCE PROCEDURES

contaminant and the method selected (Table ESP-901-1 and reference $C$ list required equipment and apparatus). Site specific requirements will be documented and approved.

VI. Safety

It is Energy Systems policy to maintain an effective program for control

of employee exposure to chemical, radiological, and physical stress which is consistent with the requirements of Mart in Marietta Corporation, DOE and OSHA established standards and requirements. All field personnel will be provided with appropriate protective clothing and safety equipment.

As a minimum, field personnel are required to wear steel capped safety shoes and safety glasses while performing this procedure. Refer to a site specific health and safety plan for detailed health and safety procedures. This plan should be reviewed prior to beginning work.

\section{Procedures}

\section{A. General}

1. Schedule for Decontamination: All heavy equipment must be decontaminated before being brought to a contaminated site, between sample points and more often if thought necessary to prevent cross contamination (e.g.: When drilling or digging through contaminated area into uncontaminated area).

A11 other equipment must be cleaned before sample collection, decontaminated between samples, if used, and decontaminated or packaged before being removed from the site.

2. Decontamination Area: Decontaminate in a designated decontamination area.

3. Documentation: Decontaminated equipment will be surveyed, inspected, and tagged by designated personnel as appropriate. 
Method Number: ESP-901

Revision Number: 0

Date: August 18, 1988

Page: 4 of 11

MARTIN MARIETTA ENERGY SYSTEMS, INC.

ENVIRONMENTAL SURVEILLANCE PROCEDURES

4. Disposal of Decontamination Wastes: Wastes generated during equipment decontamination (i.e., wash fluids, gloves) are to be packaged and disposed according to the procedures in EMP-1000 (Waste Management).

\section{B. Radioactive Decontamination}

1. Release Criteria: Criteria for releasing decontaminated equipment for use are in Table ESP-901-2 or site specific criteria, whichever are most restrictive.

Porous materials (e.g., aged wood, hollow concrete block, rubberized coatings, etc.), equipment and materials which have surfaces inaccessible to the surveyor (e.g., electric motors, small diameter pipes, etc), and items with surface coatings that could bind or cover the contamination (e.g., mud, grease, strip-coat paints, etc.) cannot be released for unrestricted use. These material will be considered on a case-by-case basis and released on authorization of the Field Health and Safety Supervisor or authorized designee.

C. Chemical Release Criteria: All equipment and materials that come into contact with known or suspected chemical contaminants are to be - considered chemically contaminated. All such equipment and materials must be decontaminated before they may be released. The item may be released for unrestricted use if, after decontamination, it is free of visible contamination.

\section{Sample Container Decontamination (External)}

1. Method: Any visible dirt, water-droplets, stains, or other extraneous material on the outside of the used sample containers must be removed before shipping or storage. Field sample containers used in radiologically controlled areas are to be monitored for radioactivity before shipping and storage. 
Method Number: ESP-901

Revision Number: 0

Date: August 18, 1988

Page: 5 of 11

MARTIN MARIETTA ENERGY SYSTEMS, INC.

ENVIRONMENTAL SURVEILLANCE PROCEDURES

\section{Contamination Control}

\section{A. General}

Decontamination fluids, equipment and apparatus must be managed in accordance with ESP-1000.

B. Decontamination Station

Decontamination locations will be based on locally specific environmental conditions.

IX. $\quad \underline{O A / O C}$

In addition to adhering to the specific requirements of this decontamination protocol and any supplementary site specific procedures, the minimum $Q A / Q C$ requirements for this activity are the following.

\section{A. Control of Deviations}

When feasible, any departure from specified requirements will be justified and authorized prior to deviating from the requirements. Deviations shall be sufficiently documented to allow repetition of the activity as actualiy performed.

B. OC Samples

The number and types of QC samples (rinse blanks, wipes, etc.) will be collected or prepared as specific in the governing plans and procedures.

\section{c. Verification}

Verification activities are required of the above practices including surveillance and periodic record audits. These activities will be documented and become part of the completed project records. 
Method Number: ESP-901

Revision Number: 0

Date: August 18, 1988

Page: 6 of 11

MARTIN MARIETTA ENERGY SYSTEMS, INC.

ENVIRONMENTAL SURVEILLANCE PROCEDURES
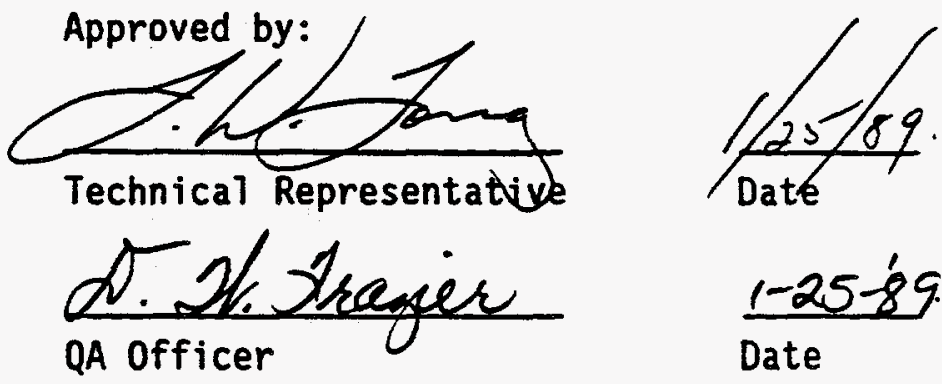

Method Number: ESP-901 
TABLE ESP-901-1

Method Number: ESF-9O: Revision Number: 0 Date: August 18, 1988 Page: 7 of 11

\section{Area and Material Decontamination Methods}

\section{(Page 1 of 4 )}

\begin{tabular}{|c|c|c|c|}
\hline Metnos" & Surtace & Action & Technicue \\
\hline Vacuum Cleaning & Dry surtace & $\begin{array}{l}\text { Removes con- } \\
\text { taminated dust by } \\
\text { suction. }\end{array}$ & $\begin{array}{l}\text { Use conventional } \\
\text { vacuum techniques } \\
\text { with efficient filter. }\end{array}$ \\
\hline Water & $\begin{array}{l}\text { All nondorous sus. } \\
\text { faces (metal. painted. } \\
\text { plastic, etc.) }\end{array}$ & Dissolves and erodes. & 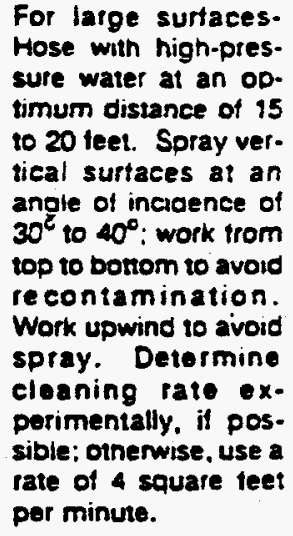 \\
\hline
\end{tabular}

Al suriaces

Steam
Nonporous surfaces (especially painteo or oiled surtaces)
Dissotves and erodes. For small surtacesBlot liquid ane hano. wipe with water and approptiase commercial detergent.

Dissolves and erodes. Work from top to bottom and from upwind. Clean surtace at a rate of 4 square teet per minute. The cieaning effieiency of steam will be greatly in. creased by using cetergents.
Goot on ory, Dorous surtaces. Avoics watet reactions.

All water eouipment may be utistzed. A. lows opetation to be carried out from a dis. tance. Contamination may be requced by $50 \%$. Water equidment may de usec tor solutions of other decontaminating agents.

Exiremely eftective if cone immediately atrer spill ano on non. porous surtaces.

Contamination may be recuced ap. proximatesy $90 \%$ on painied suriaces.
Al dust must be fii. terec ou: o! exnaus: Machine is con. taminated.

Drainage musi be controlled. No: suitable for porous materials. Oilec sur. taces cannot de oecontaminatec. NC: aoplicadie on sty con. taminazed surtaces (use vacuum): no: ap. plicable on porous surfaces suen as wood. concrete. can. vas. eic. Spray will be coniaminatec.

Of little value in the cecontamination of large areas.long. standing contamin. ants, anc porous sut. taces.

Stream subjec: 10 same limitations as water. Soray nazare makes the wearınc ot waterproot ou:tits necessary.

- Segin with the firs: listed method ans then preseed step by step to the more severe method, as nesessary. 


\section{Area and Material Decontamination Methods}

(Page 2of 4)

\begin{tabular}{llll}
\hline Metnod & Surtace & Action & Technique Aovantages Disaovantages \\
\hline
\end{tabular}

Detergents

Complexing Agen:s

Nonporous surfaces lospecially unweatnered surfaces: i.e., no rust of cal. careous growth)

Nonporous surfaces (metal, painted. glass, plastic, etc.)
Nonoorous surfaces tgreasy or coaxed sur. faces. caint or plastic finishes. ete.)
Emulsifies con. taminant and in. creases wetting power of water anc cleaning efficiency of steam.

Forms soluble complexes with contaminated material.

Dissolves organic materiais joil, paint. ere.).
Rub surface 1 minute with a rag moistened with detergent solu. tion, inen wide with dry rag; use clean sur. tace of the rag for each application. Use a power rotary brush with pressure feed for more efficient dean. ing. Apply solution from a distance with a pressure propor. tioner. Do not allow solution to drip onto other surfaces. Mist application is all that is necessary.

Complexing agen? solution should contain 3\% (by woight) of agent. Spray surtace with solution. Keep surtece moist 30 minutes by spraying with solution peri. odically. After 30 minutes. flush material off with wher. Complexing agents may be used on vertieal and over. head surtaces by ad. ding chemical foam (sodium carbonate or aluminum sulfate).

Immerse entire unit in solvent of apply by wiping procedure (see "Detergents").
Dissolves indusirial film and other materials which nold contamination. Con. tamination may be reduced by $90 \%$
May require persona contact with sunace. May not be efficien: on longstanding con. tamination.
Holds comamination in solution. Con. tamination may be reduced by $75 \%$ in 4 minutes on un. woathered surtaces. Easily stored: carbonates ane citrates are nontoxic, noncorrosive.
Ouick dissolving action. Recovery of sol. ven: possioie oy distillation.
Fequires apolication for 5 io 30 minutes. Litlle penetrating power: of small value on weathereo sur. taces.
Fequires good ven. tilation anc fire precautions. Toxic io personnel. Material Duliky.

- Begin with the firs: listed methos and then proceed step by step to the more severe method, as necessary. 
TABLE ESP-SOT-T

Method Numiner:

\begin{tabular}{ll}
\hline Metnce: & \multicolumn{1}{c}{ Surtace } \\
\hline increanic Acios & Metal surtaces jespe. \\
& cially with porous \\
& deposits: i.e., nus: or \\
& calcareous growthl: \\
& crculatory pipo sys. \\
& tems
\end{tabular}

\author{
Acid Mixiures: \\ nyoroenloric, \\ suliurie \\ aceite \\ ctric aeids \\ acetates \\ citiates \\ porous oeposits): cir. \\ culatery pipe systems \\ Causties: \\ Painted surfaces \\ ealeum nyoroxice \\ porassium hyoroxiae \\ (horzzontal)
}

\section{Nonporous surtaces (especially with \\ Dissolves porous ceposits.}

Dissolves porous Use dip-bath proce. oeposits.

Sohens paint (harsh motnod).

Techniave
dure for movadie items. Acid should be kept at a concentrate of 1 to 2 normal 19 to $18 \%$ nyosochioric. 3 to $6 \%$ sulfuric acid). Loave on weathered surtacos for I hour. Fush surface with water, serub with water-detergen: solu. in pipo circulatory sys. tom 2 to 4 hours: flush with plain water. water-detergent solution. then again with plain water.

Same as for inorganie scids. A rypieal mix. ture consist ot $0.1 \mathrm{gal}$. hydrochtorie acid. 0.2 ib. sodium scetate and 1 gal. watet.

Alow paint-remover solution to remain on surtace until paint is sotrened to the point where it may be Remove remaining paint with long-hanoled serapers. Typical paint remover solu. tion: 10 gal. water, 4 tb. Iye, 6 ib. boiler compound, 0.75 it cornstaren. thon, and rinse. Leave washed off with water.
Corrosive as:ion or metal anc porous ceposits. Corrosive acion may be mooerated by addition of corresion in. hibitors to soiution.

Contamination may reauce by $90 \%$ in ? surtaces). More easiy handied than inorganic acid solution.

Minimum contas: with contaminated surtaces. Easily stored. nour (unweathered
Peisonal hazars Wea: goggles. rusope: boors. S:oves. ar. aprons. Gces ventule. ton recuirec secause of loxicisy ans ex. plosive gases. Az: mixtures snould nct be neatec. Fossicit:; of excessive corresicr il usoo wilnou: in hibitors. Sultunc as:c not ettective on cai. careous cepcs:ts.
Weathered surtaces may reoutre pro. treatmen:. Same satery preeaunons as reguirec tot inorģanie ecies.
Personal hazare (will: cause Durnsi. Feac. tion slow: tnus. in is ns: officient on venieal $c$ : overheac surtaces. Shoule no: do used on aluminum or magnesium.

- Segin with the firs: listee methes anc then s:eceec stes sy step so the more severe metnod. as nezessary. 
TABLE ESP-901-1

Method Number: ESP-90?

Revision Number: 0

Date: August 18, 1988

Page: 10 of 11

\section{Area and Material Decontamination Methods \\ (Page 4 of 4 )}

\begin{tabular}{|c|c|c|c|c|c|}
\hline Methoo & Surtace & Action & Teennique & Advantaçes & Disaovantages \\
\hline Trisodium Phosphate & $\begin{array}{l}\text { Painted surfaces (ver- } \\
\text { tical, overnead) }\end{array}$ & $\begin{array}{l}\text { Softens paint (mitd } \\
\text { metnod). }\end{array}$ & $\begin{array}{l}\text { Apply hot } 10 \% \text { solu. } \\
\text { ton by rubbing and } \\
\text { wiping procedure } \\
\text { (seo "Detergent). }\end{array}$ & $\begin{array}{l}\text { Contamination may } \\
\text { be reduced to } \\
\text { tolerance in one or } \\
\text { wo applications. }\end{array}$ & $\begin{array}{l}\text { Destructive effec: on } \\
\text { paint. Should nc: De } \\
\text { used on aluminum o: } \\
\text { magnesium. }\end{array}$ \\
\hline Abrasion & Nonporous surtaces & Removes surtaces. & $\begin{array}{l}\text { Use conventional pro- } \\
\text { cedures. suen as } \\
\text { sanding. filing, and } \\
\text { chipping: keed sur. } \\
\text { face damp to avoid } \\
\text { dust hazard }\end{array}$ & $\begin{array}{l}\text { Contaminasion may } \\
\text { be reduced to as low } \\
\text { a level as oesired. }\end{array}$ & $\begin{array}{l}\text { Impracticable to: } \\
\text { porous suriaces be- } \\
\text { cause of peneration } \\
\text { by moisture. }\end{array}$ \\
\hline Saneblasting & Nonporous surtaces & Removes surtaces. & $\begin{array}{l}\text { Keep sand wet to less- } \\
\text { en spread of con- } \\
\text { camination. Collect } \\
\text { used abrasive of flush } \\
\text { away with water. }\end{array}$ & $\begin{array}{l}\text { Practical for targe sur- } \\
\text { face areas. }\end{array}$ & $\begin{array}{l}\text { Contamination } \\
\text { spread over area } \\
\text { must be removed. } \\
\text { Contamination cust is } \\
\text { personnel nazarc. }\end{array}$ \\
\hline Vacuum Elasting & $\begin{array}{l}\text { Porous and non- } \\
\text { porous suntaces }\end{array}$ & $\begin{array}{l}\text { Removes surfaces: } \\
\text { traps and controls } \\
\text { coniaminated waste. }\end{array}$ & $\begin{array}{l}\text { Hold tool flush to sur- } \\
\text { tace to prevent es. } \\
\text { cape of contamina. } \\
\text { tion. }\end{array}$ & $\begin{array}{l}\text { Coniaminated waste } \\
\text { ready tor disposal. } \\
\text { Salest aorasion } \\
\text { method. }\end{array}$ & $\begin{array}{l}\text { Contamination o! } \\
\text { equipment. }\end{array}$ \\
\hline
\end{tabular}

- Begin with the first listed method and then preceed step by step to the more severe method, as necessary. 
Method Number: ESP-901

DRAFT

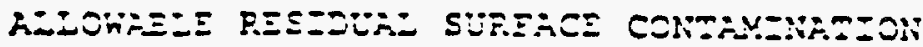

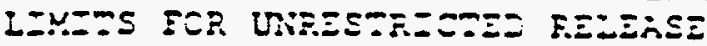

Revision Number: 0

Date: August 18, 1988

Page: 11 of 11

\begin{tabular}{|c|c|c|c|}
\hline NUこンニこE。 & 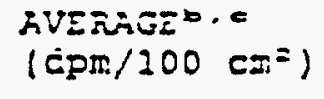 & $\begin{array}{l}\text { MEIIYUTMOC. } \\
\left(C \mathrm{pm} / 100 \mathrm{~cm}^{2}\right)\end{array}$ & 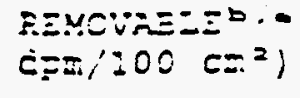 \\
\hline $\begin{array}{l}\text { U-na:, U-235, } \\
U-238, \text { and } \\
\text { associated decay } \\
\text { pzocucts }\end{array}$ & 5,000 alpha & 15,000 alpha & 1,000 eZFi: \\
\hline $\begin{array}{l}\text { Taznsu=anics, } \\
R a-226, \quad R a-228, \\
T h-230, T h-228, \\
P a-231\end{array}$ & 100 & 300 & 20 \\
\hline 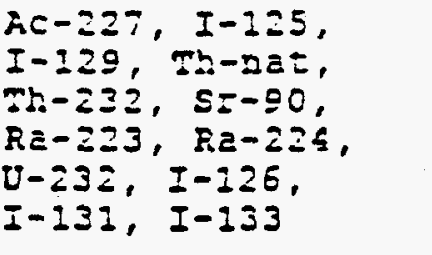 & 1,000 & 3,000 & $=00$ \\
\hline $\begin{array}{l}\text { betza-gamma } \\
\text { emiニ=eIs (nuelides }\end{array}$ & $\begin{array}{r}5,000 \text { bete- } \\
\text { ganime }\end{array}$ & $\begin{array}{r}15,000 \text { beta- } \\
\text { gama }\end{array}$ & $\begin{array}{r}1,000 \text { be } \begin{array}{r}\text { b- } \\
\text { gamma }\end{array}\end{array}$ \\
\hline
\end{tabular}

With decay modes

other than alpha

exission of sporzaneous

Eission) except $5 \pi-90$

and others noted above.

- Where sulface contamination by both alpha- and beta-gama-emitzing nuclijes e::ists, the linits established for alpha- and beta-gamm-emitisng nuslices should aprly ircependentiy.

- As used in tais table, dom (ajsintegrations per minute) meass the late $0 \equiv$ emissior by rajioarzive mareria! as derermined by corzactidg the cour:s pe:

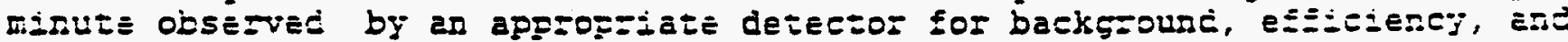

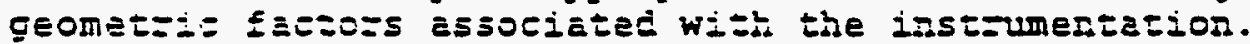

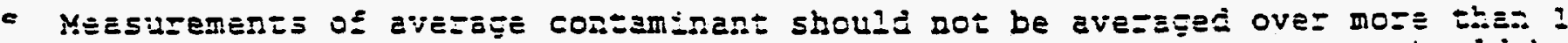

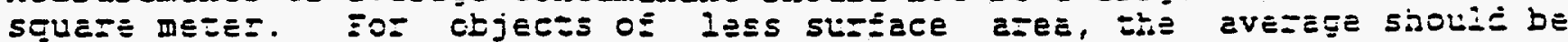
cez:Ved foI eish such objecs.

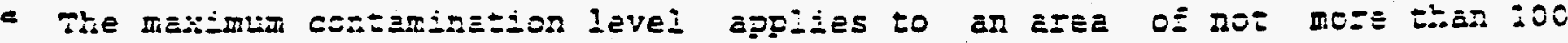
$\mathrm{si}^{2}$.

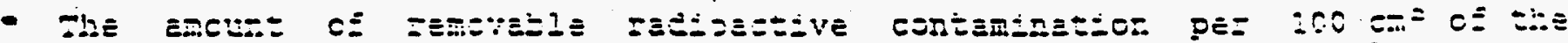

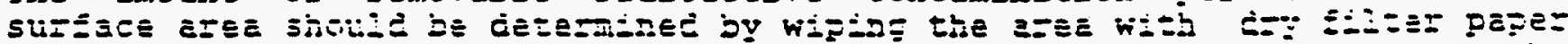

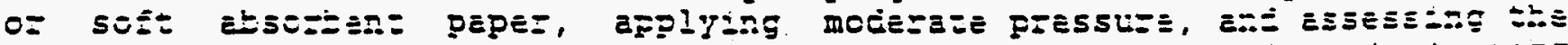

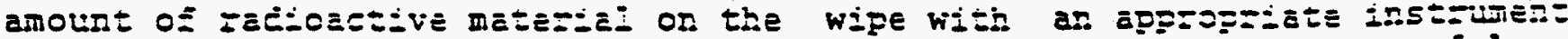

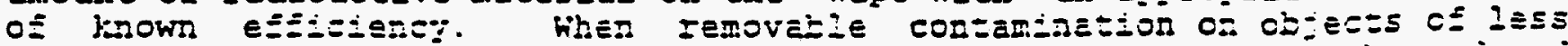

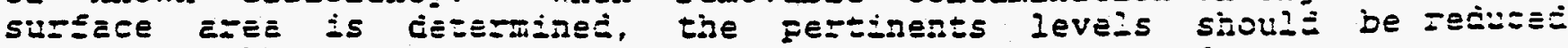

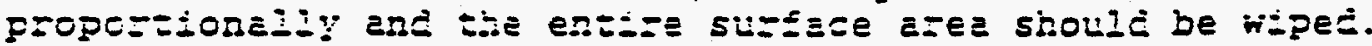

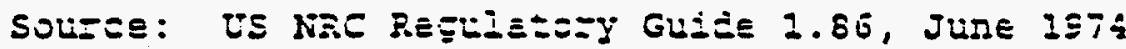


MARTIN MARIETTA ENERGY SYSTEMS, INC.

Environmental Restoration Division

WAG 6 Environmental Monitoring Program

Number ER/WAG 6 - FOP 9, Rev. 0

Page 1 of 2

Issue Date 10/13/1993

Subject: Sample Labeling

\section{PURPOSE}

The purpose of this Field Operations Procedure (FOP) is to describe the standard method and equipment required for labeling all samples collected for the Waste Area Grouping (WAG) 6 Environmental Monitoring Plan. This procedure is in accordance with Martin Marietta Energy Systems, Inc., Environmental Surveillance Procedure (ESP-) 500.

\section{REFERENCES}

Kimbrough, C. W., Long, L. W., and McMahon, L. W., eds. 1988 . Environmental Surveillance Procedures, Quality Control Program, Martin Marietta Energy Systems, Inc., ESH/Sub/87-21706/1, Oak Ridge, Tennessee, September 1.

\section{SCOPE/LIMITATIONS}

This FOP applies to the labeling of samples collected at WAG 6.

\section{DEFINITIONS}

Bar Code Sample ID - Unique string of numbers attached to a sample container that is used for identification by WAG 6 data base.

\section{REQUIREMENTS}

- Sample labels

- Black, indelible ink pen

\section{RESPONSIBILITIES}

Sample Task Leader - The Sample Task Leader is responsible for ensuring that procedures are followed and for determining what actions will be taken in circumstances that require variation from the procedures. All variances from the procedures will be documented by the Sample Task Leader and reviewed by the Field Task Manager.

Field Technicians - Field Technicians are responsible for informing the Sample Task Leader of any variances and for completing all required forms. 
MARTIN MARIETTA ENERGY SYSTEMS, INC.

Environmental Restoration Division

WAG 6 Environmental Monitoring Program

Number ER/WAG 6 - FOP 9, Rev. 0

Page 2 of 2

Issue Date 10/13/1993

Subject: Sample Labeling

\section{QUALITY ASSURANCE AND QUALTTY CONTROL}

Sample labels will be numbered sequentially throughout the sampling program to ensure that no two samples have the same ID.

VIII. TRAINING

All site personnel will receive procedural training before work begins.

\section{ACTION STEPS}

- Fill in all blanks on the sample label using indelible black ink.

- Affix clear adhesive tape over each completed sample label after it is placed on the sample bottle.

X. REQUIRED RECORDS

- Sample labels

XI. ADMINISTRATION

The Field Task Manager is responsible for administering this procedure.

\section{APPROVAL}

All procedures and instructions generated by and/or applicable to the WAG 6 Environmental Monitoring Program must receive the signed approval of the WAG 6 Project Manager and the Environmental Restoration Quality Assurance Specialist.

Effective date: November 1.1993

\section{APPENDIXES}

This FOP has no appendixes. 


\section{DISTRIBUTION}

1. H. L. Boston

2. C. B. Foust

3. R. R. Lee

4-6. D. M. Matteo

7-8. P. T. Owen

9. R. E. Saylor

10. P. A. Schrandt

11. G. W. Thompson

12. P. S. Wood

13. ORNL ER Document Management Center

14. Central ER Document Management Center

15. Laboratory Records Department

16. ORNL Patent Section

17. D. M. Carden, DOE Oak Ridge Operations Office, P.O. Box 2001, Oak Ridge, TN 37831-8541

18. J. P. McMullen, CDM Federal Programs Corporation, 800 Oak Ridge Turnpike, Oak Ridge, TN 37830

19. J. T. Sweeney, DOE Oak Ridge Operations Office, P.O. Box 2001, Oak Ridge, TN 37831-8541

20. Office of Assistant Manager for Energy Research and Development, DOE Oak Ridge Operations Office, P.O. Box 2001, Oak Ridge, TN 37831-8600

21-22. Office of Scientific and Technical Information, P.O. Box 62, Oak Ridge, TN 37831 